Florida International University

FIU Digital Commons

$10-9-2018$

\title{
Plant Pedagogies, Salmon Nation, and Fire: Settler Colonial Food Utopias and the (Un)Making of Human-Land Relationships in Coast Salish Territories
}

Janna L. Lafferty

Florida International University, jlaff004@fiu.edu

Follow this and additional works at: https://digitalcommons.fiu.edu/etd

Part of the Human Geography Commons, Nature and Society Relations Commons, and the Social and Cultural Anthropology Commons

\section{Recommended Citation}

Lafferty, Janna L., "Plant Pedagogies, Salmon Nation, and Fire: Settler Colonial Food Utopias and the (Un)Making of Human-Land Relationships in Coast Salish Territories" (2018). FIU Electronic Theses and Dissertations. 3863.

https://digitalcommons.fiu.edu/etd/3863

This work is brought to you for free and open access by the University Graduate School at FIU Digital Commons. It has been accepted for inclusion in FIU Electronic Theses and Dissertations by an authorized administrator of FIU Digital Commons. For more information, please contact dcc@fiu.edu. 


\section{FLORIDA INTERNATIONAL UNIVERSITY}

Miami, Florida

PLANT PEDAGOGIES, SALMON NATION, AND FIRE:

SETTLER COLONIAL FOOD UTOPIAS AND THE (UN)MAKING OF HUMAN-

\section{LAND RELATIONSHIPS IN COAST SALISH TERRITORIES}

A dissertation submitted in partial fulfillment of the

requirements for the degree of

DOCTOR OF PHILOSOPHY

in

GLOBAL AND SOCIOCULTURAL STUDIES

by

Janna Lafferty

2018 
To: Dean John F. Stack, Jr.

Steven J. Green School of International and Public Affairs

This dissertation, written by Janna Lafferty, and entitled Plant Pedagogies, Salmon Nation, and Fire: Settler Colonial Food Utopias and the Un/Making of Human-Land Relationships in Coast Salish Territories, having been approved in respect to style and intellectual content, is referred to you for judgment.

We have read this dissertation and recommend that it be approved.

Rod Neumann

Juliet Erazo

Laura Ogden

Whitney Bauman

Gail Hollander, Major Professor

Date of Defense: October 9, 2018

The dissertation of Janna Lafferty is approved.

Dean John F. Stack, Jr.

Steven J. Green School of International and Public Affairs

Andrés G. Gil

Vice President for Research and Economic Development and Dean of the University Graduate School

Florida International University, 2018 


\section{DEDICATION}

This dissertation is dedicated to Bonnie Barnes.

Your example of what it means to give, care, love, adapt, be strong, and hold spaces of refuge for others is unparalleled in my eyes. 


\section{ACKNOWLEDGMENTS}

Bringing this dissertation to fruition would not have been possible without being the recipient of so many others' generosity, time, input, and support. Before acknowledging them, I would like to express my gratitude to FIU for awarding me with the Dissertation Evidence Acquisition Fellowship in 2016, which provided necessary support to conduct this research. I would also like to thank the Social Science Research Council for selecting me as a Dissertation Proposal Development Fellow (DPDF) and funding my pre-dissertation research in the Pacific Northwest.

I want to first acknowledge Gail Hollander, my advisor, who has been unwavering in her encouragement and guidance since taking me on as her advisee in the very early stages of my Ph.D. career. Dr. Gail Hollander has inspired me, opened doors for me, and believed in my future as a food geographer all along the way, while introducing to me to ideas, spaces, and people that propelled me forward. Gail's mentorship allowed me to explore this topic creatively while grounding me in important networks of scholarly inquiry. I have been so thankful for having a wildly brilliant committee. Rod Neumann has encouraged my potential and the evolution of my work from the very beginning, and his comments on my work have challenged in me in ways that I know made this project better. I am beyond grateful that Laura Ogden as seen this project through. I was delighted to have Dr. Erazo join my committee, and am thankful to her for giving me words of encouragement and offering insights to help deepen and expand my ideas. I also want to thank Whitney Bauman for his enthusiasm in joining the committee somewhat late in the game and brining a religion and nature perspective to this work. 
Certainly this dissertation would not have been possible without the warmth and wisdom of the team members of Tend, Gather, and Grow. These superlative people make the world around them better and have inspired me to approach life in terms of tending. Without Elise Krohn's ability to see what others have to give, my experience working with this wonderful group of people would have never happened. My project expanded in in important ways along the way for having met Heather Day of Community Alliance for Global Justice. Her commitments to community and justice are unparalleled, as is her strength and kindness. I have been in awe of the work she accomplishes through CAGJ, and the extent to which she has oriented her life around building a world otherwise. The contagious wisdom and hope of the Muckleshoot Food Sovereignty Project and Valerie Segrest's tireless work is something I have strove to be worthy to write about.

I owe my survival in the field to Erin Carll. The love, wisdom, and camaraderie of my friends, Erin and her partner Scott Tebeaux, sustained me emotionally and physically while I was in Washington trying to make it all work. Thank you for your interest in my work and my wellbeing, and for being sources of inspiration in so many ways.

If I have not made it known to Joyce LeCompte how much I looked up to her, and how desperately grateful I was for her kindness and encouragement while I was figuring out the narrative my work, I hope to find a way to do so. I want to thank her for treating me like a colleague and friend, and introducing me into the beautiful world of plants living from the western slopes of the Cascade Mountains to the Salish Sea.

My colleagues at FIU have been a source of inspiration, friendship, care, and relief. It had been an honor and pleasure to be part of this community. I especially want to thank Billy Hall, Oceane Jasor, Jacqueline Lyon, Kimiko Tanita, Alex Huezo, and 
Defne Sarsilmaz. Lucky for all of us, Kiyomi Tsuyuki became an extended part of this community. I feel extremely fortunate to have crossed paths with all of you this way, and to have seen you evolve as scholars, and more importantly, people with tremendous moral depth and clarity.

Finally, I want to thank members of my family for being the ultimate source of love and support. Above all, I want to acknowledge my mother, Bonnie Barnes. There are not words enough to express how thankful I am to have your infinite encouragement and care. You have been a model of strength and a life giver thousands of time over. Everything I do has been made possible by you. I give so much thanks to my sisters, Kelly and Lindsey, whose sweetness, wisdom, and friendship have kept me going many times. I am so lucky to journey through this life with you. My partner, Michael Faulkner, your patience, love, and belief in me, especially during this last push, have meant everything to me. You have lifted me from abysses of anxiety and doubt to help me get to the other side of my Ph.D. program. I do not know what I would do without a best friend as insightful and loving Jessica Maher. I also want Ellen and Bruce Faulkner to know how much it has meant to me that they cheered me on the entire way. I love you all so much.

Finally, I want to acknowledge my father, Terry Lafferty, whose memory has inspired and motivated me as I pursued this goal. I love that my research brought me to a place you called home and made me feel close to your spirit. 


\title{
ABSTRACT OF THE DISSERTATION \\ PLANT PEDAGOGIES, SALMON NATION, AND FIRE: \\ SETTLER COLONIAL FOOD UTOPIAS AND THE (UN)MAKING OF HUMAN- LAND RELATIONSHIPS IN COAST SALISH TERRITORIES
}

\author{
By \\ Janna Lafferty \\ Florida International University, 2018 \\ Miami, Florida \\ Professor Gail Hollander, Major Professor
}

As knowledge about the constellating set of environmental and social crises stemming from the neoliberal global food regime becomes more pressing and popularized among US consumers, it has brought Indigenous actors asserting their political sovereignty and treaty rights with regards to their homelands into new collaborations, contestations, and negotiations with settlers in emerging food politics domains. In this dissertation, I examine solidarities and affinities being forged between Coast Salish and settler food actors in Puget Sound, attending specifically to how contested sovereignties are submerged but at play in these relations and how settler desires for belonging on and to stolen Indigenous lands animate liberal and radical food system politics.

The dissertation presents my ethnographic fieldwork in South Puget Sound over a period of 18 months with two related Coast Salish food sovereignty projects that brought Indigenous and settler food actors into sustained collaboration. One was a curriculum development project for Native and regional youth focused on the revitalization of Coast 
Salish plant landscapes, knowledge, pedagogies, and systems of reciprocity. The other was a campaign to counter the introduction of genetically engineered salmon into US food markets and coastal production facilities across the Western Hemisphere.

I engage Indigenous critiques of settler colonialism to complicate Marxian, Deleuzian, and Foucauldian analyses of North American alternative food politics, while doubling back to consider the ways the disavowal of ongoing Indigenous dispossession functions across these literatures and the social practices they influence, ultimately to consider how food-centered scholarship, environmentalism, and politics in North America stand to be transformed by Coast Salish refusals that are bound up with food, eating, and nonhuman life. This project is unique in attending to how settler colonial theory, Indigenous critical theory, and Indigenous politics in North America enrich and complicate the literatures provincializing modernity's Nature-Culture divide, as well as a largely Marxian and antiracist critical food studies literature. It contributes to settler colonial studies as a project of redefinition for the study of US politics and society while specifically bringing that interdisciplinary project into the ambit of North American critical food studies scholarship. 


\section{TABLE OF CONTENTS}

CHAPTER

PAGE

INTRODUCTION: Settler Colonialism, Food, and Apocalypse..........................1

The Un/Making of Progressive Farming............................................ 4

Settler Colonialism and the Redefinition of North American Critical Food Studies.....6 Indigenous Food Sovereignty and the Provincialization of Agriculture.............. 10

Plant People, Salmon, and Fire...................................................13

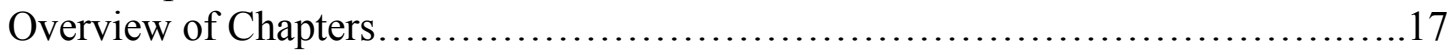

CHAPTER 1: Locating the Research: Theories and Geographies of Settler

Colonialism .22

Research Methodology: Decolonizing Research Methods and Rewriting the

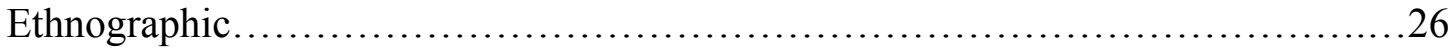

Research Objectives and Questions.............................................38

Literature Review and Theoretical Contributions: Haunting Agriculture......................41

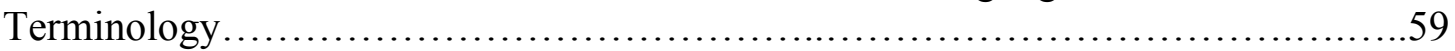

CHAPTER 2: Food, Agriculture, and Colonization in Coast Salish Territories from the Mid-1 $1{ }^{\text {th }}$ Century to the Present...................................................65

"New World" Agriculture, a Colonizing Episteme and Land Regime .................68

(Un)Making Foodscapes and Terra Nullius in the Northwest........................75

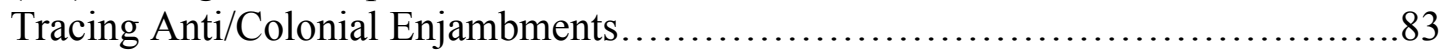

The Roots of "Alternative" Agriculture in Washington State.........................86

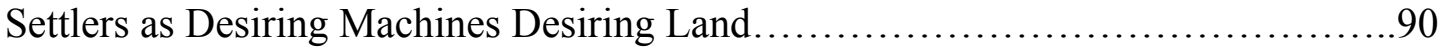

CHAPTER 3: Plant People and the "Cacophonies" of Settler Agro-Localism:

Indigenous Land Pedagogies and Urban Agriculture's Geographies of Disavowal.... 92

Stinging Nettle Stories: Allusions to Incommensurability in Food-Based Solidarity

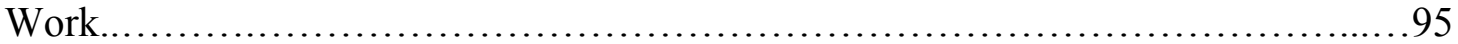

Geographies of Justice and Disavowal in South Puget Sound Urban and Local

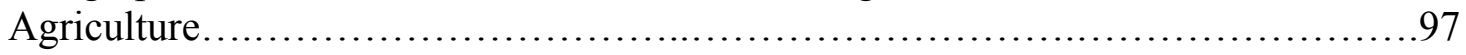

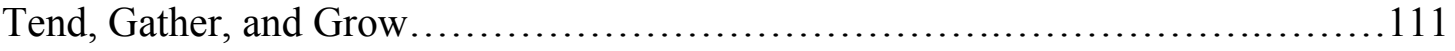

Becoming Accountable to Unsettling Geographies................................129

CHAPTER 4: Monsters of Domestication: Reflections on Wilderness, Decolonizing Materialisms, and the Specter of Genetically Engineered Salmon from Coast Salish

Territories.....

Salmon and Coast Salish Homelands.............................................137

Nation Building and Salmon Depletion........................................142

The Specter of Genetically Engineered Salmon Production..........................152

Indigenous Resistance to GE Salmon in Salish Country..............................161

Toward a Geo-politics, not Cultural Politics, of Salmon.............................176 
CHAPTER 5: Landscape Fire and (Un)Forgetting: How Burning in the Salish Sea

Prairies Points to an Ethic of Solidarity Beyond the Commons ...........................189

Fire Ecology in the Cascades Before, During, and After Settlers....................195

cabidac: Coastal Garry Oakscapes and Camas Prairies................................209

Indigenous Food Sovereignty, Co-management, and the Trouble with the

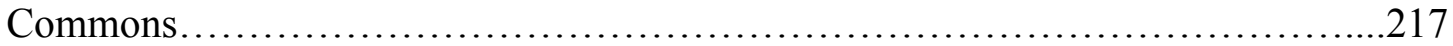

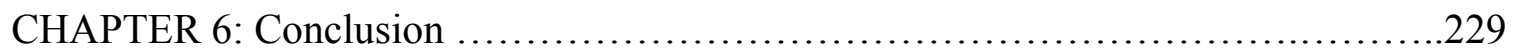

Contribution to Research Areas and Theoretical Literature............................234

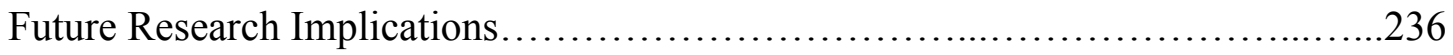

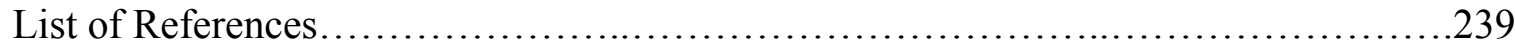

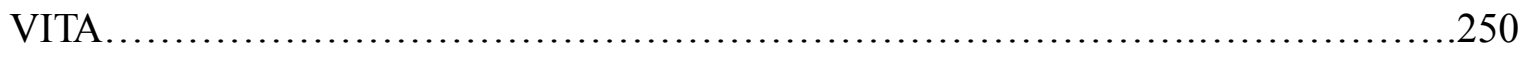




\section{TABLE OF FIGURES}

FIGURE

PAGE

Figure 0.1 Map of Salish Sea Country by Deborah Reade.............................xii

Figure 0.2 Map of Washington State, Puget Sound, Cascade Mountain Range https://www.ezilon.com/maps/united-states/washington-physical-maps.html xiii

Figure 3.1 Tend, Gather, and Grow team members gathering dandelion to make dandelion biscuits (April 16, 2016).

Figure 4.1 Roger Fernandes speaking at the Wild Salmon Cookout at wəłəb?altx ${ }^{\mathrm{w}}$ (March 17, 2017)....

Figure 4.2 Valerie Speaking at the Wild Salmon Cookout at wəłəb?altxw (March 17, 2017).

Figure 4.3 Traditional Muckleshoot Fishermen preparing smoked salmon

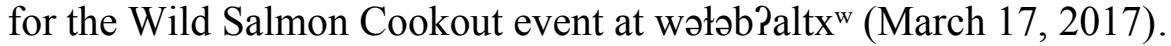

Figure 5.1 Elise harvest huckleberries in a meadow within the Muckleshoot Tamanamus Forest. (August 13, 2016).

Figure 5.2 Example of Big Huckleberry, from our day harvesting in the Muckleshoot Tamanamus Forest. (August 13, 2016). .200

Figure 5.3 Tend, Gather, and Grow team members digging camas on the Chehalis Reservation. Note the tree line against the open meadow. (May 28, 2016). 


\section{Map of Salish Sea Country}

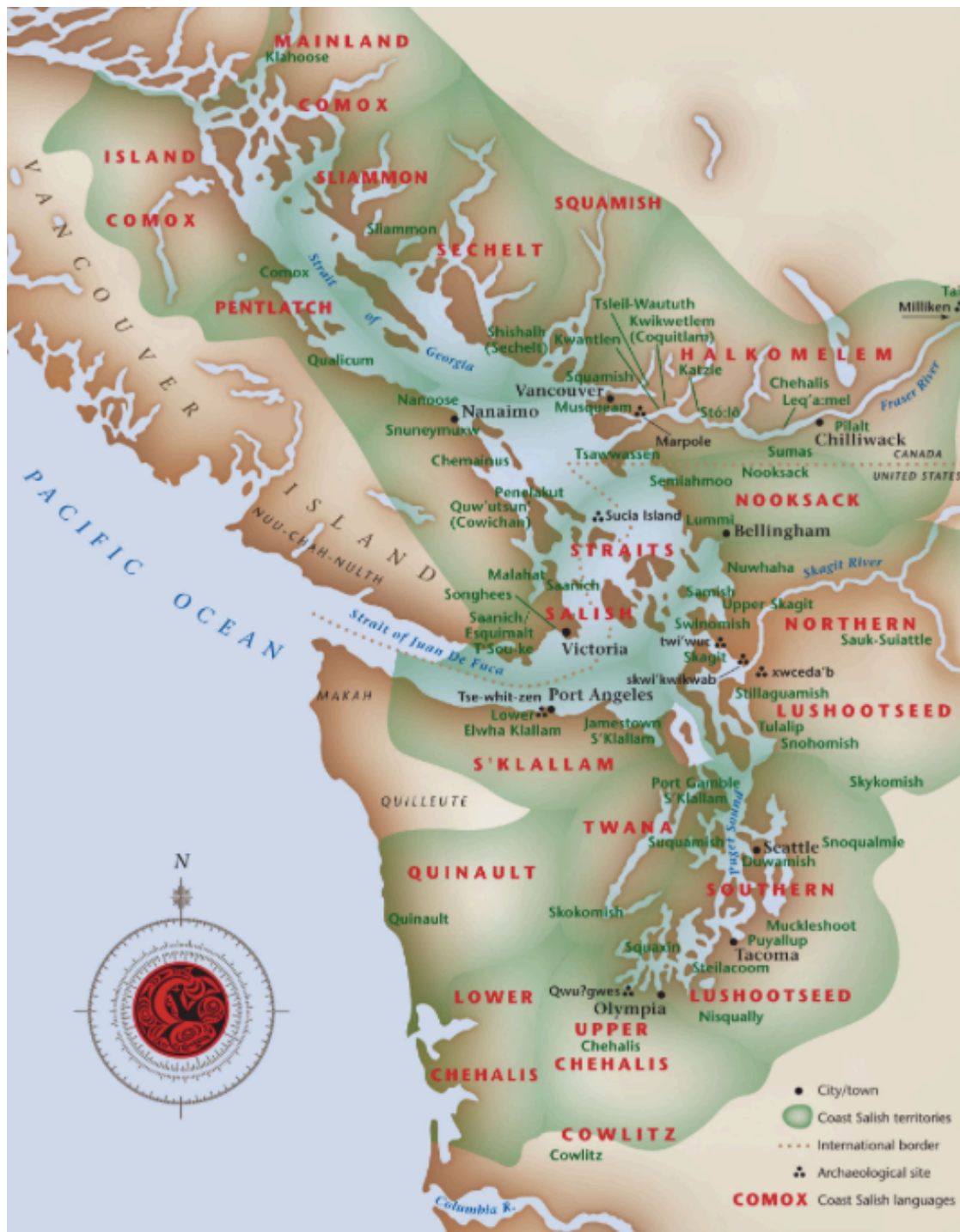

Figure 0.1 Map of Salish Sea Country (D)borah Reade 


\section{Map of Washington State, Puget Sound Region, and Cascade Mountain Range}

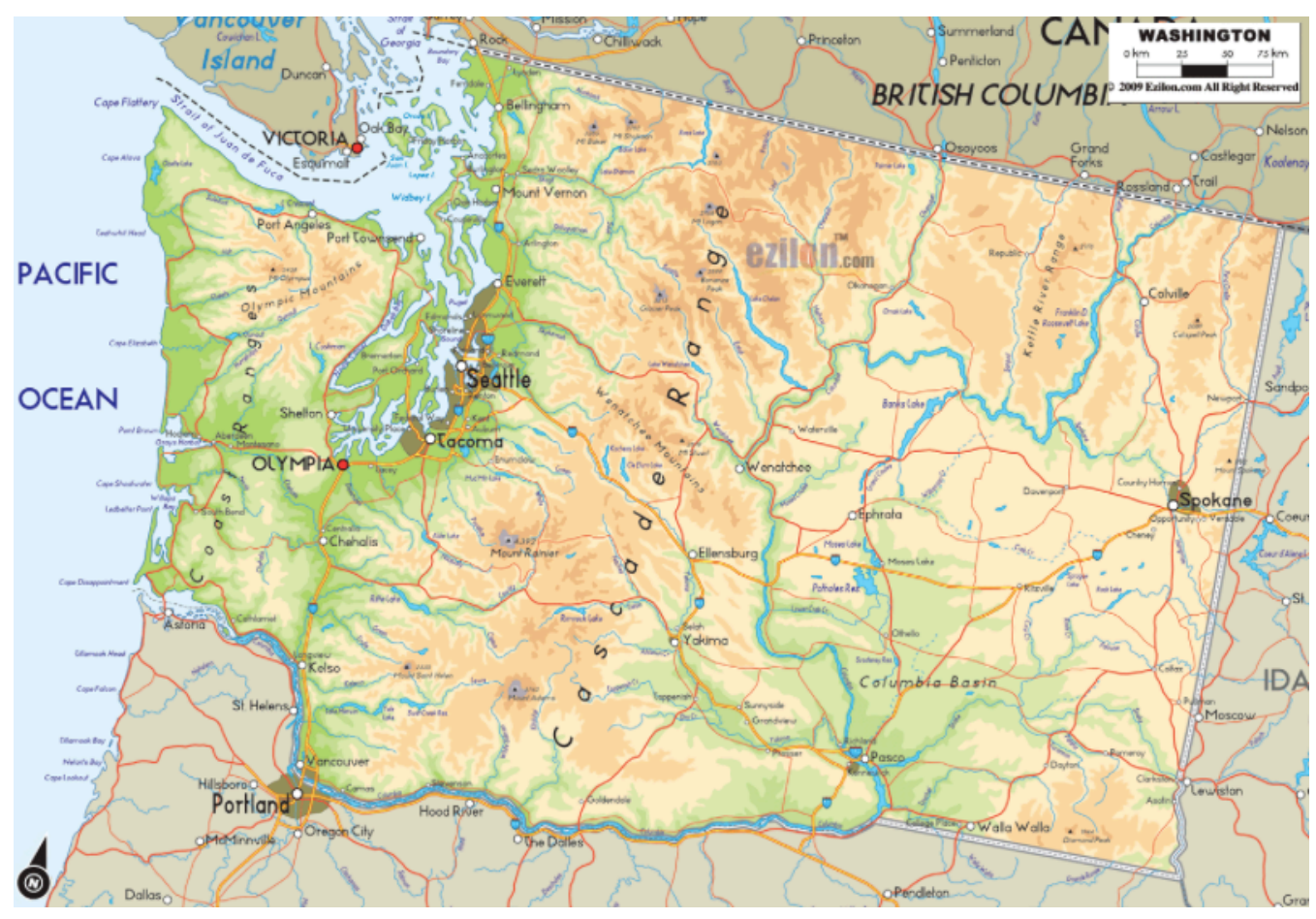

Figure 0.2 Map of Washington State, Puget Sound, Cascade Mountain Range https://www.ezilon.com/maps/united-states/washington-physical-maps.html 


\section{INTRODUCTION: Settler Colonialism, Food, and Apocalypse}

Part of the Yakama Nation's traditional harvesting grounds for big huckleberry reside in the subalpine elevations of the Gifford Pinchot National Forest, where surviving tracts of these berry meadow landscapes are open to public, tribal, and commercial use through the Special Forest Products program. Big huckleberry, a nutritionally and antioxidant dense fruit that grows in seral habitats of high-country Cascadian forests, is one of the Yakama's most sacred foods. Their ability to harvest this and many other foods constitutes a treaty right that their ancestors made pains to secure as a condition for trading lands to the US government in 1855 . In recent years, tribal members have made their way to these grounds to find the most accessible bushes already scavenged and bare. This particular episode of vanishing and landscape contestation has co-occurred with the popularization among American consumers for local, seasonal, organic foods. Companies like Tillamook increasingly send commercial pickers into these mountain meadows to harvest several weeks before the berries are ripe, ensuring a longer shelf-life for a product that acquires 'value-added' through the marketability of its localism, terroir, and presumed sustainability.

The Yakama, whose lands stretch east from the leeward side of the Cascades, along with many Coast Salish tribes whose territories span from the western slopes of the mountains to the Salish Sea, have for over a century contended with diminishing mountain huckleberry meadow ecologies under settler land use regimes. This is both a result of and in addition to being removed and policed away from landscapes that their ancestors produced and maintained over thousands of years. For 'local food' enthusiasts, purchasing the kinds of products that a company like Tillamook sells marks a healthier 
consumption choice as well as a market-driven push toward a more environmentally sustainable food system. For the Yakama, the disappearing berry harvests resulting - at least in part-from emerging markets for more local, place-specific, organic foods, mark yet another iteration of the ways settler colonizers unmake human-land relationships and disappear Indigenous life, diverting flows of vitality to settlers, who by definition perceive Indigenous lands as fodder for moral rectitude, utopic regime-building, and prosperity.

Tillamook highlights that its history stems back to the when the "first settlers arrived in the Tillamook Valley in the 1850's (covered wagons and all)" (Tillamook 2018) as part of its current marketing strategy. Branding the company's steadfastness to its pre-industrial, rural, agrarian pioneer beginnings, Tillamook describes itself as "made of up of nearly 100 farmer families [most of which] have been farming in Tillamook County for multiple generations" (ibid.). At the same time, it advertises that "Tillamook' is a Native American word for 'Land of Many Waters"” (ibid.). This simultaneous invocation and erasure of the Tillamook people, who were and continue to be dispossessed of lands deemed to be more rational and moral as farmland, as part of the company's branding rhetoric instantiates how cultural and territorial appropriation work together. It also illustrates something about the historical and ongoing dynamics between settler agrarian food utopias, and Indigenous presence, sovereignty, and futurity.

The recent struggle around huckleberry picking in the Gifford Pinchot National Forest, a federal landholding that has a convoluted history of displacing and partnering with Washington State treaty tribes, constitutes just one among numerous vignettes that exemplify a set of ongoing territorial, political, and environmental contestations that 
some Native actors in Western Washington are increasingly articulating in terms of Indigenous food sovereignty. While this term, concept, and politics has circulated in transnational social movements and social science literatures for nearly a decade, what it means in the context of settler nation-states like the US, as distinct from the postcolonial states and franchise colonial milieus in which it emerged, has become a point of perplexity within North American critical food geographies.

The significance of the unceasing efforts the Indigenous peoples of Salish Sea Country have made to continue to produce food according to prior social and socioecological orders despite the US settler-state's variegated means of eliminating these human-land relationships, have been obscured both in settler society and scholarship as siloed resource, environmental, and cultural rights struggles. So too has been the role of Anglophone farming, gardening, and agriculture as a key mechanism in this regard, rendered natural as a righteous, progressive, civilizing enterprise that legitimates resettlement on already sovereign lands. From Native fisheries to cultivated plant landscapes like mountain berry meadows, root gardens, and camas prairies, agrarian logics and practices have been key in rendering these sites illegible as productive, anthropogenic spaces - as already labored by and belonging to other societies. Enlightenment political philosophies of agriculture worked to deem them, rather, as wild and thus available for settlers to realize their particular visions of human progress. Underneath the increasing popularization in settler society of turning to more inclusive, more sustainable modes of farming in order to more perfectly realize the promises of liberal US democracy, lies a fundamental dynamic of incommensurability that remains to be theorized, grappled with, made visible. As Native Northwest food actors articulate 
what Indigenous food sovereignty means for their own people and polities, they assert a broader political imaginary that brings together ostensibly separate legal skirmishes and at the same time, I argue, they provincialize and trouble utopic settler dreams of farming.

This dissertation presents my ethnographic fieldwork in South Puget Sound over a period of 18 months with two related Coast Salish food sovereignty projects that brought Indigenous and settler food actors into sustained, un-easy collaborations. One was a curriculum development project for Native and regional youth focused on the revitalization of Coast Salish plant landscapes, knowledge, pedagogies, and systems of reciprocity. The other was a campaign to counter the introduction of genetically engineered salmon into US food markets and coastal production facilities across the Western Hemisphere, which I situate within longstanding salmon-centered social and political struggles in Coast Salish territories in the context of Indigenous/settler-state relations. Throughout these engagements, I identified how multicultural, anti-racist, and anti-capitalist food movement frameworks share in common with neoliberal nature privatization schemes modes of disavowing the geopolitics of Indigenous sovereignty within the US settler state.

\subsection{The Un/Making of Progressive Farming}

Consumers in the Global North have increasingly identified industrial agriculture as one of the primary mechanisms stoking global ecological crisis. Thanks to a set of popular writers, celebrity chefs, as well as grassroots movements in the US, many Americans can recite a kind of shorthand for the ways globalized, monocultural 
agricultural production moves the Earth toward Climate Change and the Anthropocene ${ }^{1}$, the now popularized if controversial term naming a markedly anthropogenic geological epoch marked by species extinctions, ecological collapse, and precarity for life.

The current food regime relies on synthetic and chemical inputs that have toxified waters, lands, and human and nonhuman bodies in ways the state now makes meek, capital-friendly attempts to regulate as a matter of public health and resource management. Industrial monocropping depletes the soil far faster than terran beings and processes can replenish it. It entails enormous hydrological and carbon footprints—some of the largest in the world of any one human activity, and it has engendered a food supply ridden with calorically ample, sugar-filled, chemical-laden, and nutritionally-scant foods linked to dramatic rises in morbid chronic diseases. It has engendered a mode of animal husbandry that not only raises ethical questions about the life conditions of domesticated animals, but that has proliferated food borne illnesses, the specter of antibiotic resistance, and consumption patterns requiring multifold times the energy, water, and land cover to feed humans. Debates abound regarding how this ecologically unsustainable way of producing and distributing food imbricates with social inequities and pathologies, along with the most effective ways to address these interlocking social and environmental problems. What enjoys wide consensus, however, is that attention to how people produce,

\footnotetext{
${ }^{1}$ I especially concur with the ways Donna Haraway, Jason Moore, and Anna Tsing have troubled the 'Anthropocene' as a way of naming this epoch, particularly its invocation of and attribution to a kind of "species being," rather than particular humans, perhaps fossil burning humans, and the ways capitalism and proto-capitalisms have re-organized socioecological life across the planet. Yet because these processes and their implications warrant "a big new name" beyond Climate Change, the interdisciplinary, crossdisciplinary popularization of "Anthropocene" at least permits a shorthand for necessary conversations about human-planetary geology nexuses.
} 
distribute, and consume food must be central to human attempts to avert or mitigate the apocalyptic specter of the Anthropocene.

It is here that Indigenous intellectuals, critical theorists, and food actors make a profound interjection. As Anne Spice articulates, in fact "the environmental disaster we now face has its roots in a prior and continuing apocalypse, in the attempted elimination of Indigenous worlds" (Spice 2018). In this dissertation, I explore how this colonial disremembering of an apocalypse that settler colonizers seek to avert but have already dispensed, has always already been inscribed in their utopian visions of food production and concomitant ways of relating to the land. Without looking at these dynamics, contemporary iterations settler food utopias - ranging from technocratic and neoliberal to anticapitalist and socialist — are likely to remain the ouroboros of settler coloniality that they have always been. Consider, for example, the nostalgic, counter-cultural return to "homesteading" in the 1960's, both a rejection of US modernity and deeply infused with settler colonial visions about relating to the land premised on prior state-sanctioned modes of Indigenous dispossession, erasure, exclusion, and elimination. Not coincidentally, the 1960's iteration of homesteading is one of the contemporary US alternative food movement's foremost predecessors.

\subsection{Settler Colonialism and the Redefinition of North American Critical Food Studies}

In outlining a racial biopolitics of food, Rachel Slocum and Arun Saldanha proclaim that in addition to getting at the heart of what it means to be human, food deciphers the "amaranthine question of 'difference' under capitalism" $(2013,1)$. Taking settler colonialism and Indigenous sovereignty as my points of departure within food 
studies, in this dissertation I examine how food gets at the ways race, capitalism, and biopolitics analytics disavow and misremember the colonization of Indigenous lands (cf. Byrd 2011, 67). I argue that we might further get at the heart of the relationships between "the Human," freedom, and a/modernity by bringing critical food geographies existing out in the world and within scholarly literatures into conversation with the breaks ${ }^{2}$ Indigenous scholars have made with Marx, Deleuze, and Foucault. To do so, I specifically think with those whose work flows from or engages with critiques of settler colonialism as a vast rethinking of post + coloniality by foregrounding the distinct structure of colonization via settlement.

Settler colonial studies does not simply put forth another type of colonialism to be described, but offers "a mode of analysis that has repercussions for any diagnosis of coloniality and for understanding the modern conditions of freedom" (la paperson 2017). Land figures at the forefront of this analysis. Unlike external colonialismtaken as the universal form in the postcolonial canon-land (not labor) expropriation is settler colonialism's desideratum. Colonizing settlers desire territorial settlement, to "indigenize" themselves on already inhabited and sovereign land(s). To do so requires corporeally and epistemically (Tuck and McKenzie 2016, 59) removing Indigenous people from the land, which entails not simply an historical event, but a logic and structure involving particular kinds of legal regimes, political philosophies, systems of land tenure, rationalities, fictions, and natures. Like other settler colonialisms of the

\footnotetext{
${ }^{2}$ When I speak of "breaks," I do not refer to an outright rejection, but something more akin to a deep revisioning involving engagement with a concept, its genealogy, and its political and theoretical limitstaking it up anew in specified ways by putting it into relationship with structures, processes, and thinkers previously unaccounted for.
} 
modern world, the U.S. settler-state is an incomplete, contradiction-laden, and, arguably, failed project. While U.S. settler colonialism marks a present condition, alternative politics and futurities open up in the exposition of both its presence and its contingencies.

Indigenous sovereignty is inherently geopolitical within settler contexts been obscured by preferences within anthropology, geography, and related disciplines to interpret Indigenous life in terms of the biopolitical (Simpson 2012), the cultural (Simpson 2014), the racial (Byrd 2011; Simpson 2014; Tuck and Yang 2012), or as remnant relative to transoceanic US Empire, globalized capitalism, and/or their hoped for future afterlives (Byrd 2011; Coulthard 2014). I seek to contribute to a literature that "geotheorizes" (Tuck et al. 2014) Indigenous food struggles in order to make legible post-possibilities to a global political economy of ownership by expropriation and an attendant regime of The Human constituted by U.S. settler modernity.

Perhaps unlike any other area of inquiry, food studies foregrounds the multifarious, co-constitutive linkages between human societies and "nature." If, as Jessica Cattelino asserted in her plenary remarks to the Society for North American Anthropology in 2011, settler colonial theory is a project "not of inclusion but of redefinition for the study of U.S. politics and society," the North American critical food studies is a crucial site for this work and (re-)theorization (2011).

Historically settler colonial studies has attended to colonialism's effects on human life. In recent years, however, Indigenous Studies scholars and others have begun to bring it into conversation with scholarly turns seeking to unmake modernity's Nature-Society divide—ontological pluralism, multispecies anthropology, new 
materialism in order to understand how settler colonialism entangles human and nonhuman life (Todd 2017). A new project is opening up in these intersections, one that recognizes "the subjugation of land and nonhuman life to deathlike states" in order to support the Human "as a kind of biopolitics that exceeds the Foucauldian conception of biopolitics as the neoliberal disciplining of the modern, bourgeois, ‘human' subject” (la paperson 2017). Such a project would center Indigenous thought, dispossession, land, life, refusal, and futurities not only because critical theory "risks becoming complicit in [settler colonialism qua] the very structures and processes of domination that it ought to oppose" (Coulthard 2014, 12), but because these are analytically agentive sites that offer new kinds of political critique.

In this dissertation, I examine North American critical food geographies in conversation with Indigenous theorizations of settler colonialism, including the breaks this scholarship makes with Marx, Deleuze, and Foucault. I ultimately argue that doing so helps to make legible an alternative ethic of solidarity for alternative food system work that is less governed by liberal logics of exclusion and inclusion than what Jodi A. Byrd, Alyoshia Goldstein Jodi Melamed, and Chandan Reddy — building on the work of Dene scholar Glenn Coulthard and Michi Saagiig Nishnaabeg intellectual Leanne Betasamosake Simpson — call "grounded relationality" (2018). This grounded-ness emphasizes accountability to Indigenous laws and philosophies that "remind us that knowledge must always remain grounded as the land calls to us and for us to find our place within the ongoing acts of interconnectivity that surround us" and capacity-building for "relationality outside the logics of propriation" $(2018,11)$. I show that this line of theorization opens up new accountabilities, forms of praxis, and futurities for food- 
centered scholarship and political practice. Specifically, I engage three places Indigenous critiques of settler colonialism enrich the dominant theoretical terrain of critical food work: 1) localism and place-based education/relating, 2) racial biopolitics and justice, 3) multispecies relationality and modern technology nexuses.

\section{Indigenous Food Sovereignty and the Provincialization of Agriculture}

During the months I spent engaged in participant-observation work with Coast Salish food sovereignty organizers and settler food actors in South Puget Sound, I became attuned to patterns and themes of polite interjection. These qualifying remarks articulate profoundly differing temporalizations and territorializations of food system politics, the implications of which are seemingly difficult for settlers to register. Consider the pregnant nuance of a comment voiced by Valerie Segrest, a Muckleshoot Tribal member, Native foods educator, and founder of the Muckleshoot Food Sovereignty Project. She asserts that while the alternative food movement

is getting bigger and is providing a sort of space for people to talk about a different food system and do community gardening and all of that important and wonderful work, there's also an ancient system that has been here a long time and fed people a long time, and we have to remember that system. For tribes at least, food sovereignty carries a different weight (Segrest, 2015).

It is typical of Valerie to affirm her affinity with those in the Northwest who are working to become citizens of their own food systems, develop an ethic of place-based relationality, and who are seeking to move away from modes of industrialized food production contributing to ecological collapse, labor exploitation, and social dislocation at multiple sites and scales. Yet here, as on many other occasions, Valerie purposively 
interrupts the epistemic and political assumptions settler food actors bring to the table. She reminds her would-be collaborators that the splendor of the Northwest landscape does not merely constitute a part of Nature that humans might treat more or less responsibly, but comprises the territories of long-sovereign peoples with deep time, coproductive relationships to these lands. She gestures to the fact that the relations Northwest Native peoples have with the US settler-state continue to be marked by contestations over existential human-land relationships, and that there is a lack of accountability on the part of settlers to the Indigenous social and legal orders that shape those relationships.

While settler colonial studies and critical food studies, as I will argue, have not yet seemed to have become close interlocutors, it is fitting for food to make its way to the center of analyses of the US qua a settler colonial society. Food "can be seen as the most direct manifestation of the relationships between Indigenous Peoples and homelands, and it consequently occupies a central place in traditional thought" (Patel and Gray 2014, 437). As I have heard Valerie Segrest say many times, "tribal sovereignty is food sovereignty." Food is the first and most important thing her ancestors spoke to, she avers, when her people negotiated treaties outlining what tribal sovereignty might mean in relation to US sovereignty.

In recent years, scholars have increasingly gestured to unexamined points of tension or disarticulation between the broader alternative food movement and Indigenous (food) politics in the U.S. and other settler societies. In 2009, Scott Morgensen began to assert that few scholars, if any, were drawing connections between settler colonialism and an increasingly popularized "local food" movement in the United States (2009), even 
though it entails new ways of rehearsing "the normative formation of settlers" to feel “emplaced on Indigenous lands" (Morgenson 2011). In 2011, historian Coll

Thrush remarked that despite the popularity of the 'local food' movement in the Pacific Northwest, Indigenous foods and ways of eating remain invisible to settler society in that region (2011). In 2014, Raj Patel observed that "there is an unrecognized conflict in the recent drive toward the local and sustainable, since in many cases, farmers - even small farmers and community gardeners — are sowing Indigenous Peoples' territories. Many (if not most) of these territories have an unceded or contested status" $(2014,442)$. Attending to critiques by Indigenous food sovereignty organizers in Canada such as Dawn Morrison (Secwempec), the founder and co-chair of the Working Group on Indigenous Food Sovereignty, Geographer Michelle Daigle (Mushkegowuk, Constance Lake First Nation) has argued that the "ag-centric" discourses and practices of food sovereignty and food justice in the U.S. and Canada "do not contend with the contested sovereignties internal to settler colonial states, in which Indigenous peoples continue to be dispossessed of their food harvesting grounds and waters for the state's own political and economic sovereignty" (2017, 2). "Furthermore," she asserts, "such discourses do not engage with Indigenous ontologies on and relationships with their non-human kin (land, water, animals and plants), which complicate Euro-centric notions of sovereignty that are based on Lockean conceptions of land as property that can be enclosed, owned and controlled" (ibid). Daigle goes on to observe that "contested sovereignties between Indigenous peoples and settler food actors [...] remain a crucial area of examination" $(2017,16)$. The political, geographic, and environmental boundaries and dynamics at play in the ongoing relationships between settler colonialism, food production, and Indigenous sovereignty 
remain poorly understood and untheorized at a time when people are scrambling to transform food systems from the local to global scales. It is this "crucial" gap to which this study turns.

\section{Plant People, Salmon, and Fire}

This dissertation is organized around three vignettes emerging from 18 months of research in South Puget Sound working alongside Coast Salish traditional food revitalization and tribal food sovereignty activists on a set of projects that have brought them into partnerships with settler food actors. It examines two major local food-centered projects in this region, in addition to tracing the political histories of food and land tenure that have shaped their dynamics. One was a multi-year plants-focused curriculum development project for Native and regional youth called Tend, Gather, and Grow. This project brought long-time Coast Salish food sovereignty and traditional foods revitalizers into a sustained partnership with Garden Raised Urban Bounty (GRuB), a prominent local agriculture and food justice organization based in Olympia Washington. This undertaking dealt with revitalizing Coast Salish knowledge and practices of plant-tending and cultivated plant landscapes, and often entailed broaching longstanding sites of contested land use. Two such sites involve the importance of camas prairies and huckleberry meadows as landscapes produced and maintained largely via controlled burning, which have been decimated as a result fire suppression, wilderness logics, Indigenous removal, and the agricultural logic of the (private) property/(public) wilderness divide. The second examines another long-term project and that marks the first partnership between the Seattle-based food sovereignty organization, Community 
Alliance for Global Justice, and Indigenous food sovereignty leaders in Washington State - specifically the Muckleshoot Food Sovereignty Project. This collaboration was organized around finding ways to disrupt developments by a transnational biotech company based in Massachusetts to build a global infrastructure for producing and distributing a genetically engineered salmon, the first genetically engineered food animal cleared for human consumption anywhere in the world.

Through this research I illustrate that these new, uncertain, at times fumbling solidarities and the larger network of activists, agencies, and organizations they brought into conversation reveal the ways Indigenous dispossession via settler colonialism and its local and global implications are structurally disavowed by settlers building what are widely considered to be the most radical food movements, including anti-racist food justice and food sovereignty. Also imbricated are the more mainstream food movement families of the radical movements they remain a part—urban agriculture, sustainable farming, and local food. This research shows that dreams of progress rooted in terra nullius animate practices and institutions that span the political gamut of food change politics in settler society. I also document the ways Indigenous people navigate and push back against that in order to hold space for Indigenous livelihoods under and beyond US settler colonialism. I illustrate that strategies for localization, place-based relating, and even commoning, approaching the land as a common resource for all, can be ways of reproducing settler colonial governmentality. Both finance capitalists and social movements enacting place-based alternatives to such schemes can redeploy and remake natures, environments, and geographies that commit the violence of erasing 
Indigenous pasts, presents, and futures - thus failing to see a set of alternatives to restore livability in places hurting and vulnerable to social and ecological calamity.

Yet as knowledge about the constellating set of environmental and social problems stemming from the present global food regime becomes more popularized and pressing, Indigenous food sovereignty organizing in the Pacific Northwest brings Native and settler actors into the overlapping domain of food system politics and an attendant array of multiscalar social and environmental projects and struggles—-from creating regional food councils, to salmon recovery politics, utilizing urban and suburban "green spaces," creating more localized producer-consumer networks, ecological restoration projects, and health and hunger youth intervention programs. As this happens, a set of environmental, political, and territorial clashes belie the putatively shared objectives for food system change away from an industrialized, and increasingly biotechnologized, global food regime. They are clashes that lay silent too in conflations often made in critical literatures in anthropology and geography attending to the US alternative food movement's imbrications with neoliberal capitalism, US and global anti/racism, and post/neo-colonialism.

Food system re-localization, for example, figures in both Indigenous and settler food-centered praxis, but in settler society the imagined horizon for a return to more localized food systems is Anglophone, agrarian settlement. US alternative food movements especially valorize small family farm production. If Indigenous people in the present are taken into account within this movement at all, it is usually as a racialized minority lacking equality, inclusion, and access, not as political sovereigns whose survival exposes the fictions of any US democracy-utopic farming nexus. Inclusion and 
equality are not decolonizing objectives or processes, but are themselves the values, retellings, and mechanisms of the liberal settler state. How or whether 'local food' practices impact ongoing contestations around treaty law, resource co-management, imposed settler borders, tribal self-determination, or the necropolitical materialities of settler governmentality itself have not, by and large, been part of settler alternative food politics or theories of change, just as their re-localization projects have not looked to revitalizing Indigenous landscapes, technologies, social orders, or political sovereignty. Even as new iterations of alternative food activism in settler society organize under the banner of social justice as much as environmental sustainability, their food system and land tenure alternatives - whether expanding organic farmland, bringing fresh vegetables into urban food deserts, community supported agriculture, or a return of the commonsdisavow ongoing modes of Indigenous dispossession.

What animates Indigenous food sovereignty and its broader set of land and water contestations are Coast Salish refusals to cease being Coast Salish in the face of settler colonialism's defining need for Indigenous disappearance, whether by assimilation, removal, containment, or death. It is not only unethical but, perhaps, a fantastical contradiction to assume those of us who dwell on stolen Coast Salish and other Indigenous lands can "sustainably" or "justly" farm our way out of a set of necropolitical crises that began, in the first place, with the agrarian settler land use logics, mythologies, and legal regimes developed as a means of unmaking existing lifeworlds. 


\section{Overview of Chapters}

In Chapter 1 I locate the research and myself, the researcher, geographically, methodologically, and theoretically. I outline my methodology for this research project, and review the theoretical literatures from which I draw, focusing largely on Indigenous critiques of settler colonialism and its implications for food studies scholarship oriented by political economic critique, critical race theory, and the ontological turn.

I begin to make my broader argument in Chapter 2 by putting forth an historical account of the substantial role of food and agriculture in colonial resettlement in what is now Western Washington State. In doing so, I emphasize 1) how Anglophone political philosophies and practices of agriculture are co-productions of U.S. settler colonialism, enacted not only by settler-state officiates, but settlers, which, following K. Wayne Yang I define as people who inhabit a certain kind of "structural positioning" within the US settler state (la paperson 2017). 2) That food and its attendant social, socioecologial, and spiritual relations have been at the center of Indigenous relationships of sovereignty, refusal, and resistance vis-à-vis the settler-state from the signing of the Stevens treaties in the 1850 's to the present. I argued that there is a need for a more robust discussion of the linkages between agriculture, territorial claim, and Indigenous dispossession in North America in the food studies literature on two grounds. First, "the agrarian imaginary" remains hegomonic across the gamut of alternative food system work in the U.S. Second, the critique of the agrarian imaginary we have been given by geographer Julie Guthman, while opening up important critical spaces of scholarly investigation, is articulated in a way that participates in the flattening of Indigeneity into another racialized minority, disenfranchised from land and its wealth through the racialized exclusions of capitalism, 
while locating Indigenous dispossession in the past. Guthman's Marxian/political economic analysis of a market-oriented food movement advancing organic agricultural production and consumption contributes to this kind of ellipsis in the scholarship, and the ways it either ignores or serves the misuses of the term 'decolonization' in alternative food system work. In order to do this, I analyze materials produced by the actors who initiated and have most influenced an "alternative agriculture" scene in the Puget Sound region, reading them alongside John Locke, Thomas Jefferson, and US Indian law since the mid- $19^{\text {th }}$ century.

I move on in Chapter 3 to analyze my participant-observation with Tend, Gather, and Grow to examine the dynamics between Coast Salish food sovereignty actors and a celebrated food justice/urban agriculture organization in Olympia, Washington, drawing conclusions that think with Jodi A. Byrd's concept of "cacophony" alongside scholarship on urban Indigenous land pedagogies as a decolonizing intervention to settler place-based environmentalism. First, I map out the divergent but related food politics lineages that have come to the table at Tend, Gather, and Grow. This allows me to examine implicit tensions, some incommensurable, with regard to how the relationships between people, place, and the land are imagined, and what justice entails with regard to diversity, land, place, and food. I trace changes in how staff at non-profit organization GRuB narrate human-land-place relationships as a result of their sustained engagement with Coast Salish foodways revitalizers, whose politics of resurgence and refusal confound settler land and nature logics, which I argue are inherent to agrarian progressivism and foodcentered social justice projects. Rather than merely revealing underlying conflict, I attend to the sociopolitical and philosophical possibilities that become more visible as 
incommensurable orientations to justice collide (or diverge), specifically the futurities entailed by "re-storying" human relationships to land as Indigenous, whether urban and/or currently ceded territory or not (cf. Bang et al 2014). To do this, I draw from scholarship that identifies science, place-based, and environmental education as "critical sites of struggle" where settler colonial logics are "quietly buried" (Bang et al. 2014, 2).

In Chapter 4, I examine a campaign established by the Muckleshoot Food Sovereignty Project and Community Alliance for Global Justice to put forth a settler colonial analysis of the politics around "AquAdvantage Salmon," ${ }^{3}$ the first genetically engineered animal for human consumption and its attendant transoceanic infrastructures, focusing on its imbrications with Coast Salish people and homelands. In this chapter, I seek to draw from and build on how, as salmon have become entangled with new terrains and techniques of capitalist accumulation over the last 15 years, this animal has begun to grab the attention of scholars oriented by recent theoretical turns that interrogate species boundaries and their relationships to modern technologies. While the novelties introduced through the production of a transgenic global food-commodity salmon have expanded GMO food controversies and legal battles, in the U.S. Pacific Northwest they toggle with an enduring history of salmon-centered sociopolitical struggles in the context of Indigenous-U.S. settler state relations. I take this point of articulation as an opportunity to re-conceptualize the intersection of Native fishing and water rights struggles, salmon depletion, and Washington State's position within shifting regimes of capitalist accumulation-from resource extraction in the name of nation-building to "green" global

\footnotetext{
${ }^{3}$ AquAdvantage Salmon is the name given to this patented animal by AquaBounty Technologies, Inc., the proprietary biotech company, and by which it is being marketed.
} 
capitalism. To do this, I draw from and complicate literatures conceptualizing the ways more-than-human landscapes, technology, and capitalism meet by focusing on the "politics of refusal" in Coast Salish territories as it is bound up with deep time humansalmon relationships.

I illustrate how Coast Salish politics and ontologies render legible that as a biocapitalist enterprise, AquAdvantage Salmon not only instantiates a new round of environmental enclosures under late capitalism at the level of biological and molecular processes, but turns on settler colonialism as a recursive set of logics, discourses, legal regimes, and socionatures that emerge from the imperative to "eliminate the Native." I explore how grasping this politics as a way of naming settler colonialism in the present, its contingencies, and its global movements complicates debates about the stakes, mechanisms, and post-possibilities of capitalist modernity. Specifically, I emphasize the divergences between Coast Salish ethics and politics of human-salmon relationships visà-vis technology—emphasizing memory, kinship, and the integrity of salmon nation and the human-animal ethics being conceptualized by multispecies ethnographers attending to modern technology—emphasizing the possibilities and indeterminacies of "becoming with" when animal liveliness is taken seriously.

Finally, in Chapter 5, I set out to illustrate how efforts to revitalize huckleberry meadows and camas prairies as Coast Salish fire ecologies reveal extraction and conservation / exploitation and commoning to be more isomorphic than we might imagine. I put Indigenous critiques of settler colonialism into conversation with critical food studies scholarship in a way that allows me to make the argument that while much of the critical food studies literature, along with a broader critical theory matrix, treats 
them as such, neither anti-capitalism nor Deleuzian approaches to 'worlding anew' are synonymous with decolonization, a term that is over- and mis-used in ways that have abstracted it from land/s (Tuck and Yang 2012). As theoretical orientations concerned with emancipation and livability, the anti-capitalist notion of 'the commons' as well as Deleuzian-inspired scholarship emphasizing 'becoming' are often elaborated in alternative food system work (both in scholarship and activism) without acknowledging the ways that they rehearse settler logics and safeguard settler futurity. By examining recent work Coast Salish food revitalizers are doing and the partnerships they are forging — largely through their articulations of tribal food sovereignty — in this chapter I am able to show how these dynamics model a politics and ethics of solidarity beyond prevailing emancipatory concepts in North American social science and activism within and beyond alternative food work. 


\section{CHAPTER 1: Locating the Research: Theories and Geographies of Settler}

\section{Colonialism}

I conducted my research in Coast Salish territories under U.S. (not Canadian) settler-state rule. These lands comprise what are presently called (and which I refer to as) Puget Sound, Western Washington, and the greater Seattle metro-area. Salish Sea Country spans the lands and waters of and surrounding the Salish Sea-the labyrinthine complex of coastal and estuarine waterways stretching from Canadian British Columbia to Olympia, Washington, where it becomes the southernmost point of Puget Sound. "Coast Salish" refers to the network of related political, cultural, and linguistic groups across this region. There are numerous tribes and First Nations within this culturallinguistic grouping. In present day Western Washington, members of various Coast Salish tribes belong politically to one or more distinct tribal polities, while also identifying with the broader cultural and kinship designation "Coast Salish," or to the social geography of "Salish Country," which additionally includes the Interior Salish whose lands begin on the eastern side of the Cascade Mountain Range. It is also an umbrella for a set of languages that are distinct yet related. The Coast Salish language spoken between what is now Seattle and Olympia is Lushootseed, but this overlaps with numerous others, including Twana, S'Klallam.

This particular region has received scholarly attention relating to food for multiple reasons that have heretofore been approached, conceptualized, and studied as separate topics, and have subsequently come to live within distinct scholarly literatures. The first 
being the Puget Sound "fishing wars," and the history of Native American fishing rights in the region, which in many ways culminated in the 1974 Supreme Court "Boldt Decision," "yet continues to be controversial in Washington State even as it has been lauded as one the largest Native American Rights successes in U.S. history. It has shaped the ongoing social, legal, and environmental struggles on the part of tribes to fish, manage, and protect the salmon fishery in Washington State, and their role in the entrenched politics around salmon depletion and recovery in the Pacific Northwest. The scholarship covering this topic tends to fall into legal and environmental history literatures (Boxberger 2000; Leibhardt 1990; Lichatowich 1999; Taylor 2001).

A second involves anthropological and ethnobotanical scholarship that revisits the longstanding and consequential misnomer in the ethnographic literature describing Coast Salish peoples as foragers/hunter-gatherers/fisherfolk who did not cultivate the land. This literature uses ethnographic and ethnohistorical methods to describe the vast array of Coast Salish land management techniques and the kinds of landscapes they produced, and the ways that have or continue to vanish apart from Indigenous management practices (Boyd 1999; Deur 2002; Miller 1996; Turner 2013). Ethnobiologist Nancy Turner has been at the forefront of this scholarship, generating an oeuvre of scholarship that redescribes Native land management and traditional food systems in the Pacific

\footnotetext{
${ }^{4}$ The Puget Sound fishing wars involved a series of protests and heightened clashes between police and Native Americans on off-reservation fishing sites during the 1960s and 1970s in which tribes were asserting their treaty rights to fish in these areas.

5 The 1974 affirmed the tribes' legal status as co-managers of the fishery entitled to half the harvestable catch, and their right to fish at all accustomed and usual fishing grounds.
} 
Northwest as cultivated, produced, and involving numerous sophisticated technologies and knowledge systems $(1995 ; 1997 ; 1998 ; 2013)$.

I would point to a third in how Seattle and nearby Western Washington cities have captured the attention of critical food scholars due to its relatively high number of alternative and local food activism initiatives - from sustainable farming to urban agriculture and food justice programs (see Poe et al. 2013; Ramirez 2015; Horst et al. 2017; Alkon and Mares 2012; Blecha and Leitner 2014).

In this study, I attend to how each of these spheres of activity are related to the under-examined concept Indigenous food sovereignty in this region, qua a settler colonial context. My research acknowledges, for one, how fishing and plant cultivation as domains of practice and social and socioecological struggle are integral pieces of Coast Salish life and continuous re/assertions of tribal sovereignties - constituting a geopolitical domain increasingly being articulated as Indigenous food sovereignty. The separation of these spheres of food-centered activity into distinct and separate literatures obscures the significance of ongoing practices of Indigenous food production under conditions of settler colonial rule that has for over a century sought to eliminate Coast Salish relationships with the land. Indigenous food sovereignty asserts an ongoing epistemic relationship to the land, including to changing and altered environments (whether cities or wilderness areas), constituting a refusal to cease being Coast Salish despite the explicit attempts and intentions of the settler state and settler logics to eliminate those relationships via physical death or assimilation (i.e. inclusion into the liberal, multicultural nation-state). 
My research uniquely considers Coast Salish plant cultivation practices and salmon politics together as part of what is now being asserted as a matter of tribal food sovereignty. As such, these sites of struggle constitute one of the most significant and continuous sites of struggle since the negotiation of treaties in the 1850 s, while examining "alternative" food politics in settler society explicitly in terms of its relationships to and impacts on Coast Salish human-land relationships. While concepts like localism, place-based belonging, and pluralism in and beyond food studies and activism are valorized, these terms often hide profoundly diverging meanings and sites of struggle.

Conceptualizing the geography of this work in the terms how Coast Salish food revitalizers in Washington State articulate it_- "from the Cascade Mountains to the Salish Sea," rewrites and interrupts the deep-seated and myriad ways settler food activism is rooted in an ontology of Nature that always already disavows the settler colonial present.

This geography, then, focuses less on the notion of "the urban Indian," and more on refiguring cities like Seattle, Tacoma, and Olympia as (still, always) part of the geography of Coast Salish territories, and places where Coast Salish people have continued to contend not only with state officiates, but settlers - as figures plugged into technologies of settler colonial rule - to assert sovereign relations with land, water, nonhuman life, and other sovereign human groupings, including the US nation-state. 


\section{Research Methodology: Decolonizing Research Methods and Rewriting the Ethnographic}

I approached my dissertation research as an interdisciplinary scholar working at the intersections of human geography and environmental anthropology, and trained in research methods employed across both disciplines. Food studies scholarship is inherently interdisciplinary, and constituted largely by anthropology and human geography approaches. Both human geography and environmental anthropology have been significant spaces for theorizing human-nature relationships, social productions of space, and the politics of nature. This dissertation inhabits this intersection within the broader sphere of the environmental humanities and social sciences, drawing primarily from insights of critical geographers and anthropologists of food, while bringing them into conversation with critical Indigenous theory spanning these and other disciplines.

The research methodology for this study brings together several lines of methodological critique and intervention around "ethnography" in anthropology: 1) The literature on "decolonizing research methodologies" stemming from the work of Linda Tuhiwai Smith (1999). 2) Bruno Latour's turn toward "a 'flat' anthropology” (2013). 3) Audra Simpson's recent and impactful description of "ethnographic refusal" (2014). Each

of these methodological discussions in their own way engage and critique "ethnography" as the ur anthropological method. 
On (Breaking with) Ethnography: A Preface

None of the above lines of critique seek to move away from ethnography's critical relationship with positivism. Since at least Clifford Geertz was writing on this mode of knowledge production, ethnography has been conceptualized more as a kind of meeting place that allows for interpretative and translative work than an objective encounter that speaks from nowhere. Certainly, this study aligns with the turn in social science research methodologies grappling epistemically with researcher positionality. I write from the presumption that in doing social science research, the investigator simultaneously shapes, observes, and is shaped by the world she studies and describes, and is accountable to the power asymmetries that circulate through her relationships with her research partners (Kobayashi, 2001).

Yet in another trend across the social sciences, the meaning of 'ethnography/ic' has become submerged as it is increasingly tacked on to and conflated with an array of qualitative research methods, giving us oxymoronic or nonsensical terms like “ethnographic interviews" (Ingold 2014). Timothy Ingold argues that this stems, in part, from demands for "the protocols of positivist methodology requiring us to specify—for example — how many people we intend to talk to, for how long, and how they will be selected" (ibid). He argues that these are benchmarks that inevitably devalue anthropological research. "[M]ore than any other discipline"-and the development of ethnography within it—Ingold asserts, anthropology refuses to "passively acquiesce to [the] excision of knowing from being" (ibid). Appeals to positivist measures of 
knowledge production through ethnographic research methods have obscured the significance of ethnography as a mode of knowledge production in the first place.

In developing an anthropological study for this dissertation, I concur with Ingold that ethnography, and what is worth preserving of it, entails the following. It is an art, not a science, of description that emerges from a "long-term and open-ended commitment, generous attentiveness, relational depth, and sensitivity to context" and makes room for "a real historical agency to the people who figure in them" (ibid). Yet Ingold argues that beyond this, ethnography requires a kind of turning away from one's interlocutors to write about them in a past tense, marking its difference from, for example, teaching a class or working with one's colleagues in a university setting. In it is in this way that Ingold seeks a moving away from ethnography in anthropology, in order to sustain, rather, an "undivided, interstitial field of anthropology" (ibid) — something that can be engendered by the method often confused for ethnography itself: participant-observation.

\section{Rewriting Ethnography: Decolonization, Refusal, and Provincializing Modernity}

In 1991 Bruno Latour published "We Have Never Been Modern,” commencing a series of scholarly and theoretical turns within anthropology and related disciplines that sought to provincialize modernity. Part of this entailed a kind of ethnographic inversion, what Latour would call an "anthropology of the Moderns," whose ontology bifurcates nature and culture, and themselves (violently) from the rest of humanity, whom they perceive as preceding this condition, in a teleological sense. Latour has been influential in spurring an anthropology, along with a kind of ethnographic writing, that is less concerned with describing the emic cultural logics of ostensibly discrete non-modern 
peoples ${ }^{6}$ living in the periphery of metropole and/or Empire, and more with the ways people and other beings are coping with the entanglements resulting from how modernity has radically (apocalyptically, it could be argued) transformed the Earth.

Eduardo Vivieros de Castro has articulated a profoundly influential vision for anthropology as the "permanent decolonization of thought" (2014). Yet the lineage of that literature is not isomorphic with that which has sprung from Linda Tuhiwai Smith's Decolonizing Methodologies. The former stresses how anthropologists might "take seriously" the ontological worlds of the Other, particularly Indigenous ontologies (i.e. as descriptions of multiple (co)existing natures, not simply descriptions of cultural ideas about a single natural world). Tuhiwai Smith stresses, rather, the need and pathways for Indigenous people to become researchers. The emphasis in the literature engaging her work is to prevent further death—of (Indigenous) peoples and ecologies (1999). Tuhiwai Smith's work also constitutes a critique of Western knowledge, but takes on a different set of urgencies and values in as much as is it rooted in "survival struggles" (ibid).

Anthropologist Audra Simpson's exhortation for "ethnographic refusal" as a form of analysis that accounts for Native North American Anthropology's role in a political history of dispossession. Anthropology has worked as an authoritative space of knowledge production shaping "categories of misrecognition and recognition" around Indigenous peoples in North America in ways that profoundly influence how social and political power is apportioned in nation-states like the U.S. and Canada $(2014,99)$. In North American (salvage) anthropology, it is not the construct of race but "culture" that

\footnotetext{
${ }^{6}$ To be modern is merely a conceit certain people hold and act upon (cf. Latour 1991).
} 
has defined the "conceptual and necessarily essentialized space standing in for complicated bodily and exchange-based relationships that enabled and marked colonial situations" $(2014,96)$. Even as anthropology has become a more self-reflexive discipline situating itself in histories of colonialism, "anthropological analyses of Indigeneity may still occupy the 'salvage' and 'documentary' slot and rely on enduring categories that emerged moments of colonial contact" $(2014,99)$. An "improved ethnographic form within Indigenous America" must start with an accounting of this history and move away from the anthropological focus (sometimes fetish) on Indigenous culture as a site of difference, to become more concerned with a kind of ethnography that attuned to selfrule. Sovereignty becomes key at the level of methodology in practicing ethnographic refusal, highlighting jurisdictional authority in the ethnographic writing.

Ethnographic refusal in the context of North American Indigenous ethnography takes as its point of departure the "deep context of dispossession, of containment, of a skewed authoritative axis and the ongoing structure of both settler colonialism and its disavowal" $(2014,105)$. Thus to take up sovereignty means "to think very seriously about needs and [...] involves an ethnographic calculus of what you need to know and what I refuse to write" (ibid). To the extent that this research involves observing and learning from Coast Salish people, my research objectives are less to interpret how their "cultural" logic differs from settlers, Westerners, or non-Indigenous people in terms of the meanings given to food, but more, rather, to reveal histories and ongoing practices of "inherent and unceded sovereignty" $(2014,112)$. Simply seeking to understand the cultural meanings of food to Coast Salish people does not itself interrupt the genocidal 
structures that continue to constrain and circumscribe how Coast Salish people are able to relate to the land and others through food.

In rejecting the need to present all "data" acquired in the process of ethnographic engagement, I aim to demonstrate the sovereign authority of my research partners. In the course of the dissertation, I share a number of Indigenous Puget-Salish stories. These are stories I feel comfortable sharing in this context not only because I was given permission to do so, but because they have been chosen as stories to share with wider audiences, especially in Puget Sound, with the goal of decolonizing the land in this place, and generating decolonizing solidarities for the sake of the salmon people, the plant people, the tree people, and the integrity of the many nonhuman characters with whom relations of knowledgeable reciprocity create conditions of livability. I am less concerned with revealing or examining the "struggle" of Indigenous actors, and more concerned with revealing and examining how US settler colonialism is built upon constraining Indigenous land and life in ways that affect how all life relates on what are still stolen Indigenous lands (Simpson 2016).

Together these insights constitute the scaffolding for the methodology of this research project. For one, this includes how I define the subjects of the research-most broadly, food actors "currently living within [the] presumably settled place" of Puget Sound (Simpson 2014,104). This study examines the interactions between Coast Salish food sovereignty actors in Puget Sound and alternative food movement actors who typify the food-centered projects and paradigms of US urban agriculture, food justice, and food sovereignty, and who are doing that work on Coast Salish lands, including Seattle, Tacoma, and Olympia. This project gets at how variously positioned actors are 
approaching and re/shaping entanglements made through the specific modern formation that is settler colonialism. It focuses on the role of food production in that colonial formation, as it has played out and continues to play out in Puget Sound, including the ways people both reproduce and disrupt colonial social and socioecological relationships through food and eating.

I am positioned within this project as a white, settler woman. As such, I benefit from access to land and mobility in ways some of my research partners do not. I came into this study holding a set of politics, values, and theoretical ideas about antioppression, anti-racism, and multispecies relationality that both offered a foundation of collaboration and have been deeply unsettled in the course of this fieldwork. I certainly know whose land I am on and have been on, but continue to learn and what it means to be in relationships of accountability, including what it means to be treaty partners with tribal groups involving commitments to "managing" the land together.

\section{Fieldwork Overview}

After spending two consecutive summers doing preliminary research in Western Washington, I entered "the field" in late 2014. I remained in Western Washington for the next $2 \frac{1}{2}$ years, where I worked across the South Puget Sound region primarily with two major Coast Salish food sovereignty projects that brought Indigenous and settler food actors into sustained collaborations. The first project was a long-term curriculum development project aimed at Native and regional youth called Tend, Gather, and Grow, which focused on the revitalization of Coast Salish plants—including land-based knowledge systems, anthropogenic landscapes, nutrition, and harvesting grounds and 
practices across the variegated landscapes of Puget Sound, including cities, peri-urban areas, preserved wilderness, and tribal land. The second was a more politicized project established through a partnership between the Muckleshoot Food Sovereignty Project and a Seattle-based food sovereignty organization called Community Alliance for Global Justice. This work sought to counter the introduction of genetically engineered salmonthe first genetically engineered animal approved for human consumption anywhere in the world - into U.S. food markets and coastal production facilities across the Western Hemisphere. Our work focused on tribal resistance to this nature privatization scheme, situating it within longstanding salmon-centered social and political struggles in Coast Salish territories in the context of Indigenous-settler state relations.

My involvement with these collaborations came out of relationships I was able to develop after being accepted as a "Food Sovereignty" intern for the Center for World Indigenous (CWIS) Studies in January, 2015. CWIS was founded in the wake of a Conference of Tribal Governments meeting in Tumwater, Washington in 1979. Tribal leaders adopted a resolution calling to establish a Center to archive tribal documents and undertake policy analysis that could be shared between tribes (Burden 310, 219). CWIS became a research organization with the stated mission "to advance traditional knowledge in the fields of traditional healing arts and sciences, and development through public policy analysis, clinical services, research, and education to solve problems in Indian Country" (ibid.). CWIS Chair, Dr. Rudolph Ryser, put me in contact with Elise Krohn so that she might find a role for me in the work being done around food sovereignty and Indigenous foods revitalization in South Puget Sound. Elise had been an apprentice of Skokomish Elder Bruce Miller, and has worked with Native leaders and 
communities in Washington State and British Columbia, Canada around Coast Salish plants, foods, and medicines for over 10 years. Elise put me into contact with Valerie Segrest (Muckleshoot) who in addition to being a Native foods educator and establishing the Muckleshoot Food Sovereignty Project, was involved in a wide array of foodcentered projects for her tribe, including researching a plan for an agroforestry project on a large swath of forested land recently purchased by the Muckleshoot.

In the initial months of being a food sovereignty Intern for CWIS, my work was unfocused — divided between doing research for Valerie on agroforestry, editing monographs on plants for Elise, and aiding Dr. Ryser's involvement in ways the Yakama Nation was continuing to seek redress for the harms of radioactive contamination of their lands, waters, and bodies. At this point I saw my research agenda potentially taking a variety of turns. However, it began to focus when Elise invited me to join a long-term project she had been developing based on her longstanding work with Coast Salish food and plants revitalizers (including Valerie Segrest). That cohort of educators and activists had honed in on the need for youth focused interventions, establishing ways to re-bridge the knowledge of tribal Elders with youth, restoring pathways of intergenerational knowledge transfer that have been disrupted through a variety of settler-state assimilation policies - Indian Boarding Schools and the concomitant loss of language, the breaking up of reservation land held in common into parcels privately owned by nuclear family sized households, altered ecologies due to the inability of tribes to manage them. This would be a two-year project to develop an educational tool kit that could be used by tribal schools, public schools, and other educational institutions in Western Washington. I joined Tend, Gather, and Grow as one of 22 curriculum developers comprised of Coast Salish food 
revitalizers, activists, educators, and knowledge holders; public school teachers; grant writers; local food activists; and researchers. I worked with Tend, Gather, and Grow for 18 months.

Through my relationships with Tend, Gather, and Grow members, I became introduced to a project that Valerie Segrest was helping to establish in partnership with Community Alliance for Global Justice around the issue of the introduction of AquaAdvantage Salmon — the first genetically engineered food animal—for consumption in US markets. I started to work on this project in April 2016, becoming a central figure in this collaboration. The primary actors here are Valerie Segrest and Heather Day, the Director for Community Alliance for Global Justice. The work here seeks to connect tribal resistance (largely in the form of policy and legal battles at state and national levels) to genetically engineered salmon production with environmentalists and food actors and organizations committed to salmon restoration in the Pacific Northwest. I continue to work collaboratively with Valerie and Heather on this issue.

\section{Participant-Observation}

The core of this research, then, is constituted by $1 \frac{1}{2}$ years of participantobservation with Coast Salish food actors and their non-Indigenous collaborators (including myself), from March 2016 - October 2017, plus a previous year learning from my work with Elise and Valerie on piecemeal projects while I came to understand the terrain of Coast Salish food sovereignty and revitalization work. During this time, I resided in Seattle, Washington and subsequently Snoqualmie, Washington, 40 miles east of Seattle in the Cascade foothills. My work required frequent travel to Olympia, 
Washington, as well as number of field excursions across Western Washington, including the Muckleshoot Tamanamus Forest, the Chehalis Reservation, Mima Mounds, huckleberry meadows deep in the Cascade Mountains, as well as a numerous talks, events, and meetings across Washington State. During this time I recorded events and speeches, kept field notes documenting conversations at meetings and gatherings, and photographed outings.

Tim Ingold describes participant-observation a "practice of exposure" (2014, emphasis in the original). It calls upon the "anthropologist to attend: to attend to what others are doing or saying and to what is going on around and about' to follow along where others go and to do their bidding, whatever this might entail and wherever it might take you" (ibid). Through the slow, engaged work of participation-observation, I gained much deeper insights into my research objectives than I could have simply by conducting formal interviews, surveys, or focus groups. Over a long period of time, I was able observe a range of otherwise implicit ideas, sentiments, and tensions. By being among consociates doing this work, I discovered patterns of awkwardness and interpositionmaking, sticking points, and moments of transformation in people's thinking. I developed a strong sense over time of what different food actors meant when they invoked subjects such as land, justice, place, and diversity. The experience allowed me to garner information that would not be possible otherwise, including the types interactions, topics, and practices that made people joyful, that brought out memories, that sparked reflections on traditional stories, or that spurred irritation, or the need to express differences of opinion or dissent. Beyond this, I learned a tremendous amount about the content of the work Coast Salish food revitalizers do—-from a host of knowledge about dozens of 
plants, harvesting grounds, land-tending techniques, and nutritional information, to what tribal members articulated as barriers to harvesting food, distributing food, tending the land, and performing relationships of reciprocity with nonhumans.

\section{Informal Interviewing}

Informal interviewing is a qualitative research method that is typically conducted in tandem with participant-observation (Legard et al. 2003). An informal interviewing technique allowed me to shift seamlessly from observing social interactions to entering into one-on-one conversations where I could ask questions that helped me to gain richer understandings about food actors motivations, histories, conceptualizations of in/justice in the region, and their affective and epistemic relationships to land, place, and community through food production and consumption practices. Over the course of $1 \frac{1}{2}$ years working with Tend, Gather, and Grow I conducted 11 informal interviews, in addition interviews I held with Elise and Valerie prior to Tend, Gather, and Grow.

\section{Textual Discourse Analysis}

During my time in the field, I identified and collected an array of materials for textual discourse analysis. This included: 1) Outreach materials produced by Garden Raised Bounty (GRuB), the food justice/urban agricultural organization that partnered with and housed Tend, Gather, and Grow. 2) Materials produced by Tilth, one of the founding and most influential alternative agriculture organizations in Washington State, including statements by founding members on the origins of this movement in the 1970's.

3) Statements released by The Northwest Indian Fisheries Commission articulating how 
Western Washington tribes view treaties and concomitant obligations on the part of the U.S. government and Washington State. 4) Reports produced by National Forest Service personnel in collaboration with or based on collaborations with tribal partners in reference to the initiation of co-management projects to restore huckleberry meadows and reintroduce Indigenous land management techniques. These materials helped me to understand, analyze, and historicize how settler food actors in Puget Sound advancing food justice, urban agriculture, and sustainable farming imagine righteous human-land relationships, enact affective modes of belonging to land, and attach utopian and/or emancipatory visions to space, place, and land-drawing lines of continuity between $19^{\text {th }}$ century settlers, mid- $20^{\text {th }}$ century food movement builders, and contemporary food movement actors in Puget Sound settler society.

\section{Research Objectives and Questions}

Objective 1: To interrogate whether and how alternative food activism within settler society in Puget Sound reproduces and/or disrupts Indigenous-settler state relationships.

Sub-questions: a) To what extent do settler food actors acknowledge or understand they are on and seek to sow/transform (contested) Indigenous land? b) Historically, how have the land/resource use and social goals of settler food activism affected (or not) tribal struggles with settler-state agencies (including the Department of Wildlife and Natural Resources, the National Parks Services, the Department of Fisheries and Game) and nongovernmental agents to continue to produce, provision, distribute, and consume Coast 
Salish foods according to long-established Coast Salish practices, knowledge systems, and socio-legal orders? c) In what ways do the environmental goals of settler food actors inherit and/or reinforce the doctrine of terra nullius?

Objective 2: To identify environmental, spatial, and political boundaries marking out conflicts, differences, and/or points of negotiation between Indigenous food sovereignty praxis and the social and land use practices constituting what is conventionally understood as the "alternative food" movement—particularly urban agriculture, food justice activism, and sustainable farming production and consumption.

Sub-questions: a) What are the land/water/environmental practices and goals of Indigenous food sovereignty actors and alternative food actors? What social/environmental histories do they come out of and how are those histories related? b) What kinds of landscapes and species matter/figure in these projects? To what extent are these divergent and convergent? c) How do the discourses of Indigenous food sovereignty organizers differ in significant ways from those of settler food actors, especially with regard to "land"? How do Indigenous food sovereignty and alternative food actors differently teach/reproduce ideas about land, temporality, and human-land relationships? d) What institutions do each push back against, subvert, or seek to reform, and at what scales do they exert influence (local, regional, national, transnational, global)?

Objective 3: To document the formation of interactions and collaborative projects between Indigenous and non-Indigenous food actors in Puget Sound, and to examine the 
points of conflict, incommensurability, and contingency in this work, and whether or how these collaborations are transformative or productive of new/different ways of describing and practicing food system change.

Sub-questions: a) What is bringing Indigenous and settler food actors into collaborative projects around food system change? What are the goals of their work, and through what processes are they defined? b) How do power-laden positionalities complicate these collaborations, solidarity practices, and relationships of "working across difference" (Tsing 2017). Are there patterns of disruption, disagreement, or awkwardness that emerge? What opens up or changes through these collaborations discursively, practically, or politically?

These research objectives work to locate Indigenous food sovereignty and histories of tribal food provisioning struggles in the US on one hand, and US alternative food movement actors and projects on the other, often examined separately or by way of collapsing Indigeneity into categories more readily legible by the liberal settler state, as related phenomena in the context of U.S. settler colonialism. The project seeks to examine those relationships in their historical specificity, not simply to compare a different set of politics. By centering Indigenous sovereignty, the research questions open up new lines of critique in the North American critical food studies scholarship that gets beyond how Indigenous people/s (qua sovereigns) are continually conscripted by colonial temporalities and identities in scholars' and activists' attempts to "include" or "add" Indigenous people into liberal, antiracist, or political economic theories of emancipation and livability. 


\section{Literature Review and Theoretical Contributions: Haunting Agriculture}

By centering settler colonialism, my research and analysis illustrate a need for a vast rethinking of the reliance on, deployment of, and ways of imagining "social justice" within critical food studies, while at the same time inserting itself into broader debates in anthropology and geography around liberation, decolonization, and radical ontology. Drawing specifically on Indigenous thought and critiques of settler colonialism to analyze the types of food work I studied in Puget Sound, this dissertation emphasizes the limits of Marxian, Foucauldian, and Deleuzian theories of subjection, domination, and liberation currently prevailing across critical food scholarship. This includes interjections - particularly via articulations of decolonization in Indigenous and Black Studies - into literatures that seek to provincialize modernity qua the Nature-Culture Divide (mulitnaturalism, the ontological turn, and multispecies anthropology), as well as the largely neo-Marxian, political ecological, and antiracist critical food studies literature. In this way, this research contributes to the theoretical and political naming of the settler colonial present, its contingencies, and its global movements as a way to make legible alternative post-possibilities to a political economy that has organized life (within and across nation-states) through the logic of ownership by expropriation.

\section{Indigenous Critiques of Settler Colonialism}

A concise definition of US settler colonialism might be: "Black life constructed as landless on stolen Indigenous land" (Tuck et al. 2014, 6). Consider how, in its specificity, this sentence points beyond what the sign "social justice" can flatten into a set of binaries 
(e.g. oppressed/oppressor). As we have learned from Latour, binaries proliferate monsters (1993). Jodi A. Byrd considers how under-defined notions of justice engender what she calls cacophony, "competing struggles for hegemony within and outside institutions of power, no matter how those struggles might challenge the state through loci of race, class, gender, and sexuality, [which serve] to misdirect and cloud attention from the underlying structures of settler colonialism that made the United States possible as oppressor in the first place" (Byrd 2011, xxvii). For Eve Tuck and K. Wayne Yang "social justice," a rarely unpacked placeholder alluding to redress for "fatal power difference couplings" (Gilmore 2002), houses this sort of cacophony. One interjection involves noticing that settler colonialism structures a triad, not of identities, but “structuring positions" (Tuck et al. 2014, 4) or "technologies," that entail antagonistic relationships to (selfsame) land: "the settler who accumulates rights, land and property; the native whose presence on land must be extinguished; the chattel slave who must be kept landless" (la paperson 2017).

Each involve a particular kind of relationality within that which gathers as US settler colonialism, the thing that makes Indigenous land/s into property, requiring the disappearance of Indigenous inhabitants as well as the "remaking of (African) persons into property" (Tuck et al. 2014, 3). The triad (settler/slave/native) operates "everywhere on everybody in intersecting, sometimes contradictory ways, and always with a dynamic specificity that radically changes with context" (la paperson 2017). For example, “antiblack technologies operate on Mien people in Oakland, California, in 2016 differently from how antiblack/anti-Indigenous/pro-settler technologies might try to reconstruct Mien students into Asian students just a few miles away at UC Berkeley" 
(ibid). The limits, contradictions, and elisions produced by social justice become visible when we attend to the (human-land) relationships settler colonialism makes and unmakes. Settlers tend to become rattled by reminders of "the continued presence of Indigenous peoples and the descendants of chattel slaves" because they "won't do what they are supposed to do, fade away into history by either disappearing or becoming more like the settler, the true description of the human" (Tuck and Gaztambide-Fernandez 2013, 74).

In U.S. politics and social science, white supremacy has come to define a "zeropoint" of injustice to which social justice calibrates itself (Tuck and Yang 2016, 10). While white supremacy identifies a kind of common enemy that offers up ready-made solidarities, Glenn Coulthard asserts that "the more pressing concern is to see how white supremacy creates common tools that are often picked up, reused, and recycled by efforts considered otherwise as social justice" (ibid). Because settler colonialism twists human relationships to land into human relationships to property, for example, some social justice struggles seek redress via property ownership (on/of stolen Indigenous land) (ibid). By revealing incommensurate claims to justice, these insights do not ask us to see such claims as opposed, but rather points to the need to build different capacities based on relationality rather than enactments inclusivity and exclusivity (Byrd et al. 2018, 11).

\section{The "Transformations" of Settler Colonialism}

Taught in public schools as the flawed beginnings of a profoundly righteous democratic political experiment, Unangan scholar Eve Tuck and C. Ree describe US settler colonialism, rather, as "the snake in the flooded basement" $(2013,642)$. By this they refer to and highlight that settler colonialism persists by virtue of the ways it is 
rendered unseen. They describe this colonialism formation, rather, as "not just the nefarious way nations are born [...] [settler colonialism] is an ongoing horror made invisible by its persistence" (ibid.).

Tuck and Ree put forth ghosts, horror, and haunting as a heuristic for grasping the condition of settler colonialism in North America - "the management of those who have been made killable, once and future ghosts - those that had been destroyed, but also those that are generated in every generation" (ibid.). In American cinematic storytelling, hauntings are construed as an underserved injustice bestowed on an innocent hero, who is forced to reestablish peace through some form of ritual reconciliation (Tuck and Ree 2013). From the perspective of ghosts, however, hauntings are not a demand for reconciliation, but "a refusal to stop" (Tuck and Ree 2013, 643).

Haunting is the cost of subjugation. It is the price paid for violence, for genocide. Horror films in the United States have done viewers a disservice in teaching them that heroes are innocent, and that the ghouls are the trespassers. In the context of the settler colonial nation-state, the settler hero has inherited the debts of his forefathers. This is difficult, even annoying to those who just wish to go about their day. Radio ads and quips from public speakers reveal the resentment some settlers hold for tribal communities that assert claims to land and tribal sovereignty. This resentment seems to say, “Aren't you dead already? Didn't you die out long ago? You can't really be an Indian because all of the Indians are dead. Hell, I'm probably more Indian than you are" (ibid).

"For Indigenous people colonialism is not an historical period that is now over; it continues to define the relationship between our people and the European newcomers. In this respect, Indigenous peoples live with the practical, and philosophical, effects of colonialism in the present" (Simpson 2008, 8). Yet settler colonialism insists on a 
temporality of succession that gets rehearsed widely across the academy as much as in popular culture, including the critical theory matrix.

When anthropologist Patrick Wolfe published "Settler Colonialism and the Transformation of Anthropology" in 1999, he inaugurated an interdisciplinary endeavor to broadly rethink colonialism and postcolonialism by foregrounding the distinct experience of colonization via settlement. He argued that for "all the homage paid to heterogeneity and difference, the bulk of 'post'-colonial theorizing is disabled by an oddly monolithic, and surprisingly unexamined, notion of colonialism” $(1999,1)$. For decades, postcolonial studies has explored - the "nature, consequences, endgame, and post-possibilities of "external colonialism"” (Tuck et al. 2016, 6). External, or franchise, colonialism turns on the extraction of surplus value from the labor of colonized people in lands foreign to the colonizing entity. It produces particular ideologies, logics of dehumanization, and systems of racialization. Under settler occupation, however, the colonizers come to stay. Land acquisition becomes the key object of colonial desire, requiring the "elimination of the Native" (Wolfe 1999) in corporeal and epistemic terms (Tuck 2013). Observing that the native authors of the "postcolonial canon" came from franchise, not settler or creole, colonies $(1999,3)$, Wolfe argues that the substantial heterogeneity of colonial formations have been obscured, along with ways of imagining possibilities for post- or de-colonial life in contexts where land, not labor, articulate colonial relationships.

It is only in recent years that scholars of U.S. politics and society have begun to turn their attention to settler colonialism as a distinct colonial structure. In her 2011 plenary remarks to the annual meeting for Society for the Anthropology of North 
America, anthropologist Jessica Cattelino exhorted her colleagues to consider the need for a new project, not one of inclusion, "but one of redefinition: to think of the U.S. as a settler society" (2011, 2). Cattelino defines settler societies as "especially (if not only) $[\ldots]$ the liberal democratic settler states of the former British empire with indigenous minorities: Australia, Canada, Aotearoa/New Zealand, the United States” (ibid). Drawing from Wolfe, she clarifies that the key distinction between settler and external colonialism lies in that for the former, land - not labor-expropriation is the main target. This is generative of particular kinds of myths, political philosophies, discourses, legal orders, nature ontologies that enable territorial acquisition in perpetuity (cf. Byrd 2016 Coulthard 2014). Together they work as mechanisms of dispossession that continue to "shape the relationship the settler state maintains to Indigenous communities in the present" (Byrd 2016). Thus, settler colonial studies scholars emphasize that settler colonialism is a "structure, not an event," (Wolfe 1999) in contradistinction to narratives that hold it to be the unfortunate way several great liberal democracies began-an unfortunate stain on the "arc of Progress."

Settler is not a synonym for migrant. It is not simply by virtue of being newcomers that a group of people become 'settlers'. The colonization of a place does not refer solely to the introduction of new people (or other species). As colonizers who come to stay, "they enforce their interpretations on everyone and everything in their new domain” (Tuck and McKenzie 2016, 59). Settlers benefit from, participate in, and disavow the modes of elimination requisite to settler colonization, allowing settlers to indigenize themselves on their new "homeland." 
Achieving elimination of peoples with their own long-established socio-legal orders on desired lands cannot be limited to brute violence alone, but rather multiplies the means to its ends as needed - via logics of erasure (e.g. wilderness, terra nullius), containment (e.g. reservations, off reservation-policing, restricting mobility), and assimilation, whether forced via the state through institutions like boarding schools, or through the proffering of "rights" contingent upon the adoption of foreign ways of relating to human and nonhuman life.

Yet these processes and structures get obscured in critical scholarship on US empire and racism, which in the first instance relate Indigenous dispossession as an historical precedent to, not the ongoing condition of possibility for, US transoceanic empire, and in the second through what Jodi A. Byrd calls "racial Indianness" (cf. 2011). She argues that even scholars who take up the role of "Manifest Destiny in the creation and rise of U.S. empire [...] Indians are typically spectral, implied and felt, but remain as lamentable casualties of national progress who haunt the United States on the cup of empire and destined to disappear with the frontier itself" (2011, xx). Moving into contemporary time, Indigeneity gets conflated with race or ethnicity in US social science and politics, masking "the territoriality of conquest by assigning colonization to the racialized body" (Rifkin 2012, 139). Indigeneity becomes a "trace" of settler colonialism obscured by the increasingly predominant importance of the workings of racial hierarchy in US empire. As a corollary, bringing "Indians into the nation as citizens" becomes an unquestioned "good" of multicultural and antiracist politics (ibid). 
Ultimately, Indigenous critiques of settler colonialism limn that the "ongoing life and actions of Indigenous people" provincialize the deeply naturalized notion that the US settler nation-state is “a given" (Simpson 2014, 212).

Thinking in the Places Indigenous Scholars Describe Walking Away From (and Back to) Marx, Foucault, and Deleuze

I would like to begin this section by shining a light on Eve Tuck's assertion that to identify incongruence entails an opportunity to value the incongruity. Walking away does not foreclose walking back; it often ensures it $(2010,649)$. It is with that ethos in mind that I am drawn toward attending to decisive articulations of breakage and incongruity Indigenous scholars have made with Marxian, Foucauldian, and Deleuzian thought. These are un-easy spaces that ask for new ways of being tended to.

\section{Marx/Primitive Accumulation, Commons}

Indigenous Studies' critiques of Marx's theory of primitive accumulation counter the notion that Indigenous dispossession is what paved the way for a regime of capitalist accumulation, and articulate, rather, that it is its ongoing condition of possibility. Marxian theorists in critical food studies (and elsewhere) often rehearse a narrative that settler colonialism defines a past event experienced by Native peoples, which leaves a "legacy" of land, health, and economic inequalities. This putative pastness shapes Marxian critiques of US food politics, its relationship to neoliberal capitalism, and the set of alternatives it imagines and advances, often invoking a return 
to the commons. As I further elaborate in Chapter 3, for example, I argue that geographer Julie Guthman's influential work on the "agrarian imaginary" of the US alternative food movement could be expanded in ways that identify new sorts of politics and accountabilities via attentiveness to the differences between anti-Black landlessness and Indigenous dispossession vis-à-vis her important discussion the exclusionary land-labor relationships that make up US agricultural history. In Chapter 5, I further discuss critical urban agriculture scholarship that invokes the commons as a way of defining food and environmental justice, while considering the perils of doing so without acknowledging the geopolitics of Indigenous sovereignty in the places and on the lands being discussed.

Glenn Coulthart reinvigorates conversations between Marx's theory of primitive accumulation and discussions of de/colonization within Indigenous Studies, including a pointed discussion around the ways the notion of the commons downplays "the injustice of colonial dispossession" $(2014,12)$. Coulthard is interested in chapters 26-33 of Marx's first volume of Capital because it is here that Marx most vividly links capital to colonialism (Coutlhard and Simpson 2016, 251). As powerful as he finds Marx's primitive accumulation thesis to be, Coulthard also finds a number of issues to be reckoned with in order for these writings to speak in a relevant or meaningful way to the relationship between Indigenous peoples and liberal settler states, the US and Canada in particular (ibid.).

Paramount among these is that primitive accumulation must be conceptualized not as setting the stage "for the development of the capitalist mode of production," but rather as "an ongoing practice of dispossession that never ceases to structure capitalist 
and colonial social relations in the present (Coutlhard and Simpson 2016, 251).

Relatedly, he puts forth a critique of literatures advancing a blanket "return of the commons." He explains that in settler states like the US and Canada,

the "commons" not only belong to somebody - the First Peoples of this land - they also deeply inform and sustain Indigenous modes of thought and behavior that harbor profound insights into the maintenance of relationships within and between human beings and the natural world built on principles of reciprocity, nonexploitation and respectful coexistence. [...] [this] risks overlooking what could prove to be invaluable glimpses into the ethical practices and preconditions required for the construction of a more just and sustainable world order (ibid).

Coulthart does not reject the commons outright, but he and others push back against the prevailing usage this politics and seek a revised version of when, where, and how commoning ought to be enacted.

My research captures the kinds of interruptions Indigenous food sovereignty organizers make in their relationships with settler food actors whose emancipatory visions of food justice on Coast Salish land are rooted in this kind of disavowal of Indigenous dispossession. It also illustrates how food actors are figuring out models and ethics of decolonizing collaboration, and what that entails specifically.

\section{Foucault/Biopolitics}

Biopolitics helps us to see how colonization operates through sovereignty and liberal rights, the genealogies of which Foucault ties to race war by other means. In Europe, sovereign power as the divine right of kings becomes contested and ultimately redefined as a set of rights shared by consenting citizens who participate in wars that 
defend society. The concomitant rise of modern nation-states involves a shift from the State defending itself from external threats through violence to protecting itself from internal threats through modes of disciplinary subjectivation via mechanisms, institutions, and apparatuses that shape subjects whose multiple experiences of domination are experienced as rights, desires, and responsibilities, while reproducing state power. The object of state power in this transition becomes biological life at the level of the population. Specifically, it entails not the power to make die or let live, but to "make live or let die" (Foucault 1976, 252-3). Biopolitics analytics can attune us to an array of social and political dynamics under settler and other colonialisms, as well as their afterlives and post-possibilities (see especially Moreton-Robison 2015; Stevenson 2014), or how, at least, "not to be governed like that" (Povenelli 2011, 15). Yet it is notable that within Indigenous Studies, scholars have begun to qualify their engagements with biopolitics, pointing specifically to its limitations with regard to grasping Indigenous sovereignties. Indigenous feminist scholar Aileen Moreton-Robeson has put Foucault's notion of biopolitics into conversation with critical whiteness studies to understand, among other things, how the Indigenous subject is marked by a proximity to death in settler societies, which is "made to live in and through struggle" (emphasis mine, 2015a). She says they are "drip fed the bare necessities of life through state apparatuses and mechanisms that attend to our rights" (ibid.). Lisa Stevenson's recent ethnography of Inuit life in a time of suicide makes this dynamic visible in the form what she describes as a kind of "murderous care" in the ways settler state actors seek to keep Inuit youth alive, while expecting them to die (2014). 
Yet Moreton-Robison goes on to assert that while Foucault enables us to understand how a colonizing biopower and its variegated forms operate within modernity, this concept, which itself constitutes a critique of sovereign right, holds certain Enlightenment assumptions despite Foucault's disobedience to Enlightenment thought. As complex and nuanced as they are, she argues, Foucault's conceptualization of sovereignty, rights, and biopower "still rest on centering the human subject as one that can be regulated, disciplined, enabled, and contained through its relationships with a ubiquitous sovereignty that non-Indigenous humans have produced through race war" (2015b). She reiterates that it "is operationalized by humans, against and for humans. It functions through knowledges circulating within discourses, mechanisms, apparatuses, and institutions created by humans" (2015b). It is an analytic that ties power "to the capacity of humans and their creations, is "not predicated on the connectedness of all living things," and disavows "a powerful and active Earth" (2015b). She contrasts this with how Indigenous scholars theorize Indigenous sovereignty, which posits intimate ties to "place, kin, collective rights, responsibilities, obligations, stories, land and law" (2015b). Sovereignty, she asserts, "is constituted by our histories, our culturally embodied knowledges, and the life force that connects us to our respective lands, creators, our ancestors, and all our human and nonhuman relatives, our sovereign ancestral lines to country, our umbilical cords to what has gone before us, the present, and also what is yet to come" (2015b). To do so, she asserts, is not an appeal to essential or authentic precolonial past, but simply to privilege, rather, "Indigenous logics by following a mode of Indigenous rationalities from knowledge systems that function and endure beyond the limits of colonial biopower" (2015b). 
Anthropologist Audra Simpson similarly also engages with biopolitics as a powerful analytic. Yet she has also asserted that Indigenous sovereignty has re-emerged as an anthropological topic of interest only in as much as it can be analyzed via Agamben's reworking of Foucault's concept of biopolitics - the way life itself became an object of state power in the $18^{\text {th }}$ century, marking a shift from domination via brute coercion by a sovereign power, to diffuse mechanisms of subject formation. She argues that focus on the biopolitical takes away from how Indigenous sovereignty "necessarily resides" in the geopolitical (Simpson 2011, xx). It obscures Indigenous peoples' "own modes of differentiation," to consider how "state power works on them as one would perhaps tend to raw material, to slaughtered meat, or administrable populations" (ibid). Biopolitical accounts, she argues, occur "at the analytical expense of the geopolitical" (ibid), further veiling the ongoing geopolitics of settler colonialism.

A settler colonialism analytic points to the alienation of land from life, the transformation of land into property. Land and nonhumans become alienable properties, alienated "from its own sovereign life" (la paperson 2017). Such a theoretical project involves identifying the technologies which produce and maintain those death-making (for humans and non-humans) separations.

This research approaches US settler colonialism as a structure of territorial dispossession - involving ongoing struggles over using, co-creating, and relating to lands, waters, and nonhuman life - that turns on a kind of necropower that directs vital energies (salmon, water flows) toward the settler qua the Human that not let die or make live particular groups of people, but that engender entire habitats of death. We see this across Coast Salish lands in everything from the collapse of salmon populations, to the 
decimation of biodiversity supportive landscapes like camas prairies, to the emergence of diabetes mellitus epidemic among the colonized and displaced. There are a different set of stakes and politics involved in conceptualizing not only how state power "makes [humans] live" or "lets [humans] die," pointing rather to how livability in places like Puget Sound involves social, political, and epistemic accountability to the peoples qua sovereigns being colonized in the present.

\section{Deleuze/Desire, Becoming}

Eve Tuck "confesses" that her "use of Deleuze's works has always been complicated because of [her] Indigeneity" $(2010,646)$. It is an avowal she makes in the context of discussing her engagement and, more pointedly, the break she is making with Deleuze's conceptualization of desire. Yet she relates the complicatedness she experiences with Deleuze's works as also related to his ideas about rhizomatic interconnectedness, as well as, more broadly, to "poststructuralist theory or any project that has a focus on becoming and not being" $(2010,646)$. I am interested in attending to the attachments, incongruencies, breaks, and uneasiness Tuck describes between Delueuzian theorizations — especially of desire and becoming — and her own epistemology, which she places in conversation with other Indigenous scholars and describes as "actively cultivated by [her] grandmother" $(2010,638)$. I see Tuck's engagement/break-making here to be kin to Jodi A. Byrd's more extended critiques of Deleuzian scholarship. 
For Deleuze, desire precedes power. "Reproaching" $(1984,385)$ Freudian psychoanalysis that conceives of desire in terms of a lack (in relation to an object or person that is desired), in Anti-Oedipus, Deleuze and Guattari (D\&G) figure desire not only as productive, but as the very thing which produces reality. Re-placing Nietzsche's "drives," Deleuze and Guattari describe "desiring-machines" as things that are not located in the psyche, per se, but which exist at multiple scales. Desiring-machines are linkages and disruptions in the flows between (rhizomatically) attached entities that organize any assemblage and, in turn, shape its constituents, all always in a state of becoming. They "are fueled by experiences and by the products and by-products that they themselves produce" (Tuck 2010, 640). D\&G emphasize these to be far from closed circuits, but rather defined by incompleteness, the unanticipated, and multiplicity which "flees in every direction" (Deleuze and Guattari1984, xxiii). Desire is thus not contradictory even as it explains sociological contradictions, such as why people participate in their own oppression or uphold fascism. Desire is not something beholden to a revolutionary ethos but is the only source of revolution. It is not ideological, but simply unloyal, unpredictable, multiple. Desire arranges any system of oppression while being an unstable element within it.

Having poured over Deleuze's conceptualization of desire, including his debates with Foucault (a beloved colleague) and, more obviously, his collaborations with Felix Guattari, Tuck reaches the "edges of what Deleuze will say about desire" and "wants him to say more." She wants him to say that desire is "smart— that is purposeful, intentional, agentic' that it can teach itself, craft itself, inform itself" $(2010,645)$. She feels ready for "a politics of desire that observes desire as enjoying some/a lot of self-determination, 
even as its lines of flight 'flee in every direction"” (emphasis in the original 2010, 645). She is unwilling to conceptualize desire in a way that forecloses epistemologies she has learned from her Unangan grandmother and other important practices among, in her words, many first peoples. By her accounting, desire "accumulates wisdom" and picks up "flashes of self-understanding and world-understanding along the way of life" (ibid). It is assembled across generations, "rhizomatically" linking her "past and [her] future" (ibid). This is why she can tell stories her grandmother told her with the same fullness with which these stories were shared with her, something she knows to be an important practice among many Indigenous peoples $(2010,646)$. If I read her correctly, she is saying that Deleuze's descriptions of desire deprives it of a capacity to remember.

She questions whether identifying this as a point at which she must make a break with Deleuze's concept of desire is "too dramatic." Yet she avers that her "impasse with Deleuze is not around mere semantics, not a slim difference in meaning" $(2010,647)$. Seeking to value this break in some way, this difference is complicated for her. She goes on to say that there are points of complication too that together form a knot of perplexity with many strands. She includes here that while many aspects of Deleuze's philosophy of relationality resonate with her because of her relationship to Indigenous knowledgesboth the "Indigenous academy and the stories of [her] grandmother's kitchen table" (2010, 646) — as Kim TallBear (2011) and Zoe Todd (2016) have noted and/or sharply elaborated elsewhere, there is an issue for Tuck of "false inventions and giving credit where credit is due" (ibid). She also points to a paradox and a danger faced by Indigenous people when their worldviews interface with theories and projects that foreground becoming over against being. On one hand, "the very definition of Indigeneity $[\ldots]$ 
refuses to be reduced to blood-quantum or external designation," but fluidity, relativism, and becoming can be and have been all too easily weaponized (intentionally and unintentionally) against Indigenous efforts to "reinforce our own self-determination and sovereignty when our primary relationship to the Whitestream USA has only served to tell us we are already dead" (2010, 647; see also Grande 2004). For Tuck, marking these as areas worthy of some sort of break also marks as them as worthy of value —or at least puts forth the challenge of identifying how to value these places of incommensurability.

There are echoes of the breaks Tuck articulates here in Chippewa literary scholar Jodi A. Byrd's engagements with Deleuze and Deleuzian scholarship in her book, Transit of Empire: Indigenous Critiques of Colonialism. Byrd situates these critiques in a broader conversation she seeks to open between Indigenous Studies and "the matrix of critical theory," including post-structuralsim (2011, xvii). Byrd is interested in exploring "how the cacophony produced through U.S. colonialism and imperialism domestically and abroad often coerces struggles for social justice for queers, racial minorities, and immigrants into complicity with settler colonialism" (2011, xvii). She links to this a need to better understand "the quandaries post-structuralism has left us," by which she refers to "the traces of indigenous savagery and 'Indianness' that stand a priori prior to theorizations of origin, history, freedom, constraint, and difference" (2011, xvii). She argues that, as traces, these "have often remained deactivated as a point of critical inquiry as theory has transited across disciplines and schools" (2011, xviii).

Byrd finds these traces in A Thousand Plateaus, in which Deleuze and Guattari "re/ deterritorialize America as the world, coming full circle to find its west in its east and its east in its west, a worlding anew [...] that decenters all static, grounded belongings 
and locates them instead in becomings: becoming-Indian, becoming-woman, becomingAmerica" $(2011,13)$. In doing so, they specifically valorize the figure of the "Indian without ancestry" to signify the limits of Western, arboreal thought. A Thousand Plateaus, Byrd argues, draws on "the paradigmatic Indian wilderness to encapsulate an America in which arboresence becomes rhizomatic," in order to perform "a global, nomadic reframing in which the frontier becomes, again, Frederick Jackson Turner's site of transformation, possibility, and mapping" $(2011,13)$. Thus what "we imagine to be outside of and rupturing to the state, through Deleuze, already depends upon a paradigmatic Indianness that arises from colonialist discourses justifying expropriation of lands through removals and genocide" (ibid).

Byrd raises the question of how we might "account for the historical and colonialist traces that accompany their appearance in Deleuze and Guattarri's theory as sign, while retaining sympathy for the impulse to nonrepresentational philosophy that aligns in a multiplicity of regimes of signs?" (13). Within this discussion, she says that the "rhizome, for Deleuze and Guattari, stands in Eastern, Oceanic counterpoint to the linear tree — arborescence — of descent, seed, and Western agriculture, and is short-term rather than long historical memory (emphasis mine, 14).

Both Byrd and Tuck express concerns over how theoretical approaches focused on Deleuzian becoming, which Tuck discusses more specifically with regard to the role of desire, can create "paths without memory" (Byrd 2011, 14). Byrd builds her book upon a set a theoretical foundations she describes to be "rapidly emerging as foundational to the disciplining of American Indian and indigenous studies," but which "may or may not be givens" in other critical theory spaces. First that in addition to colonization 
mattering, "peoples, place, land, sovereignty, and memory matter" (2011, xx). Another is that "despite cautions against original and originary within post-structuralist theory, $[\ldots]$ that there must be the possibility of the originary in the new world, and that it is located within the historical experiences of new world colonizations, genocides, and violences (2011, xx). Finally, "indigenous peoples must be central to any theorizations of the conditions of postcoloniality, empire, and death-dealing regimes that arise out of indigenous lands" (ibid). In chapter 4, I engage this area of contemplation with regard to the politics and stakes of the expanse of globalized salmon aquaculture into genetically engineered food salmon infrastructures. How do these they complicate or enrich the way literatures on co-species becomings and critiques of biocapitalism help us to approach and navigate these new modes of incorporating salmon lives into mechanisms of global capital at a time when biotechnology is being enrolled by a neoliberal food production regime?

\section{Terminology}

\section{Indigenous/Native American}

Scholarly debates around how to define (and who counts as) Indigenous or Native American in the US are bound up with consequential questions about people's and peoples' relationships to colonizing states and international law, including matters of political recognition, states of exemption, and claims to particular kinds of rights (e.g. to self-govern, to manage land, to practice culture and religion). In order to outline what I refer to when using these terms, I map out these debates and identify the positions that I take up in this dissertation. 


\section{Land/Space/Precedence}

Definitions of Indigeneity within international law have conventionally relied upon notions of precedence, while scholarship in a global studies context have pushed against that to highlight particular kinds of struggles over space (Patel and Grey 2014, $\mathrm{xx}$ ). Broadly, this scholarship identifies Indigeneity as involving relationships to lands (a term I use in a way that includes lakes, oceans, rivers, etc.) as well as histories of struggle with "institutions of capitalist modernity" — such as states and markets (ibid). I want to emphasize that specific affiliations of Indigenous peoples to places do not preclude patterns of mobility. It is how epistemic and material relationships to lands bring peoples into contestation with states, markets, and their attendant global power nexus that "marks the greater part of Indigenous struggles today" (ibid).

Within some of the critical literatures on international development and neoliberal governance, the category of Indigeneity has been thrown into doubt to the point of vanishing. This literature describes Indigeneity as part of the epistemic simplification of life entailed by capitalist and state actors absorbing its frontiers. Michael Watts, Anna Tsing, and Tania Li, for example, define frontiers as the symbolic and material "space at the cutting edge of capitalist expansion and state territorial control," that are reduced to simplified "modes of apprehending" (Li 2000, 153; see also Watts 1992 and Tsing 2005). State and nongovernmental agents broadly classify and represent the people inhabiting these spaces according to different frames, but ultimately impose reductionist categories. Yet for Tania Li, the assertion that "indigenous people are figments of an NGO imagination unduly influenced by imported ideas" is also a simplified characterization of indigenous identity. While her work deals with Indonesian indigeneity, Li's argument 
that "a group's self-identification as tribal or indigenous is not natural or inevitable, but neither is it simply invented, adopted, or imposed" speaks to questions of indigenousness generally. She describes indigenous identity as "a positioning which draws upon historically sedimented practices, landscapes, and repertoires of meaning, and emerges through particular patterns of engagement and struggle" $(2000,151)$. She draws from Stuart Hall's notion of 'articulation,' to think about self-identification as a "process of rendering a collective identity, position, or set of interests explicit (articulate, comprehensible, distinct, accessible to an audience), and of conjoining (articulating) that position to definite political subjects" $(2000,152)$. Cultural identities, "come from somewhere, have histories. But far from being eternally fixed in some essentialised past, they are subject to the continuous 'play' of history, culture and power" (Hall 1990, 225 qtd. in Li 2000, 152).

\section{Culture or Biology ... or Political Authority?}

The US settler state established ways of identifying the boundaries of Indigenous or Native identity in terms of biology and race — specifically via blood and bloodlines. Blood quantum qua identity has also characterized the U.S. government's historical operationalization of African American identity, only in inverse ways. The "one drop rule" rendered a person Black, such that blackness proliferates via "racial mixing."

Conversely, non-Indian ancestry diminishes one's "Indian-ness" in the eyes of the State, illustrating the aforementioned tripled positionings the settler state makes - its imperative to "disappear" the Native, while reproducing a population of landless laborers through a structural positioning produced through the technologies of anti-blackness. Native North American Anthropology helped to establish another essentialist way of 
conceptualizing Native identity that also has functioned to further the settler-state's agenda of elimination and containment of Indigenous populations - namely, culture. The "salvage" anthropology of the $20^{\text {th }}$ century that sought to document the ostensibly disappearing cultures of Native peoples in North America constructed culture in a way that captured pristine difference from Euro-American society. This construction of culture painted non-Western peoples as ahistorical, rendering ongoing change, adaptation, or syncretism legible only in terms of assimilation and moving away from Indian-ness, thus moving Native people/s into the realm of assimilated U.S. citizen, and out of the realm of political sovereign.

Thus, Indigenous theorists such as Kim TallBear, Jodi A. Byrd, and Audra Simpson elaborate why both race/biology and culture are both — though not equallyproblematic, settler-oriented ways of conceptualizing Native or Indigenous identity. While culture and cultural difference remain aspects of what constitutes these identities, these scholars alter the register for "culture," away from notions of changelessness or the sole site of "difference" vis-à-vis Euro-American ways of being. They argue that "difference" should be vested in acknowledging and upholding multiple sites of political authority, and not hinged on what colonizers might identify as alterity with regard to unchanging beliefs or practices. TallBear asserts that while Native American people "have debates amongst ourselves about whether being Native American is about being a citizen of your tribe - a political designation - or about culture and traditional practice," she tends to "come down on the side of political citizenship" (TallBear 2014). She qualifies this by affirming that "culture matters," but clarifies that "political autonomy matters too, and that helps produce a space in which our cultural traditions can thrive" 
(ibid.). What is critical is for settler society to shift their understandings of tribal belonging from settler-colonial ways of defining and controlling identity to recognizing the way sovereign tribal governments' define their members and citizens.

In this dissertation, I echo those scholars who emphasize that Indigeneity and Indigenous sovereignty in the context of the US settler state refer to identities and political formations that both precede and stand in (critical, contentious, intergovernmental) relation to the US government and its role in shaping a global political economy organized around private property. I am critical of prevailing conflations of Indigeneity within (and outside) the US as a racial category, or simply a cultural category, highlighting instead Indigeneity as a geopolitical positioning entailing relationships to lands and are constrained by but persist under settler occupation.

Coast Salish people in what is today Washington State define their relationships to the lands spanning the Cascade Mountains to the Salish Sea as existing since "time immemorial." While settler-state succession and the inevitability of settler futurity remains an intensely hegemonic and naturalized postulate among settlers, for the Coast Salish and other Indigenous peoples across the broader region, two centuries of settlerstate occupation hardly usurps what it means to have lived sovereign lives in relation to these lands millennia. The patent unsustainability of settler ways of living on this land further compound the assumption for many of the Indigenous people here that settler occupation is a temporary state affairs, and that if humans and nonhumans are to live past it, it will take—not eliminating the now-settlers and arrivants $^{7}$ who live here-

\footnotetext{
7 This usage of "arrivant" draws from Jodi A. Byrd's usage of the term, which she borrows "from African Caribbean poet Kamau Brathwaite to signify those people forced into the Americas through the violence of
} 
but undoing settler epistemologies and legal orders that restrain these relations (Tuck and Gaztambide-Fernandez 2013).

European and Anglo-American colonialism and imperialism around the globe- have functioned within and have resisted the historical project of the colonization of the "New World"' (2011, xix). 


\section{CHAPTER 2: Food, Agriculture, and Colonization in Coast Salish Territories from the Mid-19 ${ }^{\text {th }}$ Century to the Present}

Historian Frieda Knobloch calls colonization an agricultural act, as well as an agricultural idea $(1996,1)$. The word 'colonization' itself derives from the Latin for farmer, agricola. It emerges in the English language "at a time when European landowners were colonizing their own backcountry, enforcing their ownership by bringing new land into cultivation, changing the land-use practices of peasants, and forcing many of them off the land" (Knobloch 1996, 4). Colonization, Knobloch argues, “is about enforcing landownership through new, agricultural occupation of lands once used differently. [It] is a good thing, according to its supporters, regardless of the bloodshed and disruption it creates: it brings about the 'improvement' of land under cultivation - it brings culture to a wilderness" (ibid).

Patrick Wolfe describes agriculture as "a potent symbol of settler colonial identity," as its "objective economic centrality and life-sustaining connectedness to land" (Wolfe 1999, 402). He notes that in settler colonial discourse, "natives are typically represented as unsettled, nomadic, rootless, etc.," (ibid.) as ways of writing indigenous North Americans out of the landscape, establishing terra nullius for what was deemed appropriate land tenure.

In “Agrarian Dreams: The Paradox of Organic Farming,” Julie Guthman develops the notion of 'the agrarian imaginary' to critique how contemporary alternative food movement actors whitewash US agricultural history and its legacy, otherwise marked by unambiguous exclusions depending "on racial discourses that helped legitimate in the 
eyes of lawmakers who was not deserving of land, citizenship, and a wage" (2011, 1345). Echoes of this critique flourish across the critical food studies scholarship.

Geographer Rachel Slocum asserts that "the industrialized agricultural landscape of the US is made through racial ideologies active in the labor market and the institutionalized racism that removed African Americans, Mexican and indigenous people from the land" (Slocum 2010, 11). Critics of settler colonialism might tell this history somewhat differently, complicating some of the binaries (e.g. oppressed/oppressor, propertyowning/property-less; white/non-white) upon which these arguments turn.

An emerging settler colonialism analytic identifies a structural triad: "the settler who accumulates rights, land and property; the native whose presence on land must be extinguished; the chattel slave who must be kept landless," (la paperson 2017). While white supremacy "might be a prime architect in the triad," this formulation nonetheless "decenters white supremacy as the absolute pole or umbrella of oppression" (ibid). Because discourses and practices of property-making and ownership "are central to the hegemonic relations of settler colonialism and antiblackness," there are three antagonisms that "converge to typify relationships of power and place" in settler societies (Tuck et al 2014, 4). In putting forth an analysis and history of agricultural conquest in what is now Western Washington, I seek to both build on and complicate existing critiques of the legacy of land-labor relationships entailed by US agricultural history, and the ways US alternative food system actors participate in settler colonial technologies via 'the agrarian imaginary.'

I see the need for a more robust discussion of the linkages between agriculture, territorial claim, and Indigenous dispossession in North America in the food studies 
literature as being at least twofold. First, "the agrarian imaginary" remains hegemonic across the gamut of alternative food system work in the U.S. Second, the critique of the agrarian imaginary we have been given by Guthman, while opening up important critical spaces of scholarly investigation, is articulated in a way that participates in the flattening of Indigeneity into another racialized minority, disenfranchised from land and its wealth through the racialized exclusions of capitalism, while locating Indigenous dispossession in the past. Guthman's Marxian/political economic analysis of a market-oriented food movement advancing organic agricultural production and consumption contributes to this kind of ellipsis in the scholarship, and the ways it has rendered 'decolonization' either as a politics that is lacking, or a notion that gets misused in alternative food system work.

Geographer Glen Coulthard acknowledges that “Marx's primitive accumulation thesis for analyzing the relationship between colonial rule and capitalist accumulation in the contemporary period has been the subject of much debate over the last couple of decades," particularly in and between Indigenous Studies and Marxian political economy scholarship $(2014,12)$. Despite the hostility that has been generated therein, he affirms that there remains tremendous insight to be gained from ongoing engagement at this intersection, particularly "into the cycles of colonial domination and resistance that characterize the relationship between white settler states and Indigenous peoples" (ibid). In doing so, he argues for an analytical shift toward the colonial relation to better understand how dispossession is "justified under otherwise egalitarian principles and espoused with so-called 'progressive' political agendas in mind" (ibid). It is in this way that I think the "agrarian imaginary" idea stands to be deeply enriched by engagement with Indigenous critiques of settler colonialism. 
In this chapter, I put forth an historical account of the substantial role of food and agriculture in colonial resettlement in what is now Western Washington State. In doing so, I emphasize 1) how Anglophone political philosophies and practices of agriculture are co-productions of U.S. settler colonialism, which is enacted not only by settler-state officiates, but just as much by settlers. 2) That food and its attendant social, socioecological, and spiritual relations have been at the center of Indigenous relationships of sovereignty, refusal, and resistance vis-à-vis the settler-state from the signing of treaties in the 1850's to the present.

\section{“New World" Agriculture, a Colonizing Episteme and Land Regime}

\section{Locke, Jeffersonian Agrarianism, and the American "State of Nature"}

Thomas Jefferson set in motion the federal government's policy for the peoples inhabiting lands ruled and desired by the US nation-state. It flowed from his desire for the United States of America to expand as an agrarian state. Jeffersonian agrarianism constituted a political philosophy, greatly influenced by John Locke, that attached farming to democracy and the way to shape its constituents into proper ideal citizen subjects. During his presidency, he argued in favor of Indian policy that would "encourage them to abandon hunting, to apply to the raising [of] stock, to agriculture, and domestic manufacture, and thereby prove to themselves that less land and labor will maintain them in this better than in their former mode of living" (Jefferson 1801, 314 qtd. in Richards 2005). Many of his successors inherited his reasoning, including a protégé named Meriwether Lewis, chosen by Jefferson to lead an expedition to the Pacific Northwest. 
Jefferson proclaimed John Locke, Francis Bacon, and Isaac Newton to be "the three greatest men that have ever lived, without any exception, and as having laid the foundations of those superstructures which have been raised in the Physical \& Moral sciences" (Jefferson 1789). Locke's influence on Jefferson's ideas is widely acknowledged, along and in dialectal relationship with many of the Anglophone explorers, ethnologists, and philosophers for engaged debates over colonialism, within which the peoples of New World became an urgent object of taxonomic study in regard to philosophizing Man, civilization, and nature. In Two Treatises of Government, it becomes clear that Locke conceptualized America as the site for a new beginning for English civilization, whose claim upon it could be argued in opposition to that of the "Indians," as well as other European empires (1797). Locke referred to America as England's second Garden of Eden, a second chance to create righteous society out of a "state of nature." Historical Barbara Arneil argues that while overlooked for some time, Locke's Second Treatise, particularly Of Property, turns on a thesis he develops regarding the Native peoples of North America that worked as a defense of "England's colonial policy in the new world against the sceptics in England and the counter-claims of both the aboriginal nations and other European powers in America" (1996, 2). Of Property, she continues, "was written to justify the seventeenth-century dispossession of the aboriginal peoples of their land, through a vigorous defense of England's 'superior' claims to proprietorship" (ibid).

Locke outlines a definition of property upon which he builds this polemic, outlining within it a philosophical description of agriculture. He argued "that the origins of property reside in that which is mixed with labor. Thus, that which does not appear to 
have been mixed with labor is alienable" (Simpson 2014, 101). Yet he renders only certain forms of labor as legible. Locke argues, "Amongst those who are counted the civilized part of mankind, who have made and multiplied positive laws to determine property... is by the labour that removes it out of that common state nature left it in, made his property, who takes pains about it" ([1797] 2003, qtd. in Simpson 2014, 101 emphasis hers). Mohawk Anthropologist Audra Simpson asserts that these fragments from Of Property enunciate "the hierarchies of social value and their accordant rights, which were tied to the understanding of people and a social ranking as defined within an agrarian-based, panoptic view of humanity: people laboring specifically in scenarios defined by a behavioral performance of extraction or mixing, (a labor) that was sedentary, fixed, observable" (ibid). She continues that Locke's "foil for this argumentation was 'the wild Indian' of then- 'America,' who 'knew no enclosure' (ibid). Thus when Locke argues that

God gave the World to men in Common; but since he gave it them for their benefit, and the greatest Conveniences of Life they were capable to draw from it, it cannot be supposed that he meant it should always remain common and uncultivated. He gave it to the use of the Industrious and Rational (and Labour was to be his Title to it) (1690)

it is clear who, in their matured humanness, possesses the right to lay claim to land, and who, in a state of nature, does not.

Locke refers to his collection of American travelogues in his work. Simpson illustrates how Locke in turn informed explorers like James Cook, as well as the way subsequent ethnologists documented Native peoples in North America. She calls this the "traffic between theory and event [that] moved colonies into nation-states" $(2014,100-$ 
101). It "disabled future claims of Indigenous occupation and ownership of territory because, in part, their own voices were imperceptible, or unknowable, or unimportant, or were sieved through analytics or narrative forms that interpreted their aspirations in ways that were not their own and/or were unrecognizable" (ibid).

\section{Treaty-making in the "Far West"}

Fifty years after Jefferson outlined his ideas for Indian policy to Congress upon expanding the nation through the Louisiana Purchase in 1803, circumstances were changing in what the Franklin Pierce administration called the "Far West." The Commissioner of Indian Affairs during this time, George W. Manypenny, helped to establish the reservation system as policy. Manypenny began to express concerns that the removal tribes to contained areas away from "civilized society" only worked "to confirm him in his savage habits and pursuits" away from "the example and influence of the industrious pioneer" (Richard 2005). Reservations were intended at as alternative to extermination, serving as places where "civilizing forces would germinate and grow until the Indians became equal, productive citizens of the United States" (Richards 2005, 343). The treaties Manypenny forged served as a template for treaty negotiations in the Northwest, headed by Isaac Stevens. Stevens was a graduate of the U.S. Military Academy in 1839, subsequently working in military and political matters. He understood U.S. government policies, and it was clear to him that his role in securing treaties was to "extinguish aboriginal title to the land, establish the best lines for roads and railroads, and inaugurate a government that would provide the political stability necessary for the 
population to grow and the economy flourish in the Northwest sector of the nation" (Richards 2005, 344-345).

Stevens approached his errand with urgency as conflicts were already emerging as a result of the Donation Land Claim Act, which opened up Oregon Territory to homesteaders-brining in new waves of land-desiring settlers into an already inhabited region. Stevens needed to extinguish Indigenous land claims as quickly as possible to make room for U.S. expansion and avoid conflicts between settlers and tribes. While perceiving U.S. land takeover as exercise in generosity which might bring about "the great end [that is] the gradual civilization of the Indians, and their ultimate incorporation with the people of the Territory" - in other words, the elimination of the Native people through containment and assimilation (Stevens 1853). For Stevens, the treaty making process took on the character of force (Schneider 2016, 11). He would draft the treaties in advance, therefor precluding mutual participation in the contents of the contract (Blumm 2006). Oral histories reveal that the Plateau Indian nations "felt that the American negotiators were in a hurry to conclude previously written treaties, not by honest negotiation but by dictation and coercion, even to the point of threatening the Indians to agree to the treaties or face bloodshed (Trafzer 2005, 400). Those who attempted to avoid treaty-making with Stevens in order to retain land title and avoid relocation to a reservation were eventually pushed off their homelands as settlers poured in, something tribal leaders who signed treaties anticipated (ibid).

When Stevens initiated negotiations with delegates from Puget Sound tribes and bands (including what are today the Nisqually, Puyallup, and Squaxin Island tribes) for the Medicine Creek Treaty in 1853, he insisted on using Chinook Jargon, a limited pigin 
language instead of using a translator fluent in the Salishan languages that his interlocutors spoke (Schneider 2016, 11). The Medicine Creek treaty served as the template for the next nine treaties Stevens negotiated with tribal groups across what is now Washington State. Stevens wanted to "admit as few reservations as possible with the view of finally concentrating them in one" (Richard 2005, 347).

Even under the coercive and uneven conditions of these "negotiations," most of the Stevens treaties ended up including a similar passage that has since become key in legal struggles over land use. The passage is about food provisioning - something the tribal delegates at the Medicine Creek treaty and subsequent negotiations insisted. The passage guarantees

the exclusive right of taking fish in all the streams, where running through or bordering said reservation, is further secured to said confederated tribes and bands of Indians, as also the right of taking fish at all usual and accustomed places, in common with the citizens of the Territory, and of erecting temporary buildings for curing them; together with the privilege of hunting, gathering roots and berries, and pasturing their horses and cattle upon open and unclaimed land (Medicine Creek Treaty 1854).

George Gibbs, an ethnologist hired by Governor Stevens to aid the treaty negotiations, wrote "[The tribes] require the liberty of motion for the purpose of seeking, in their proper season, roots, berries, and fish, where those articles can be found" (Gibbs). Seeking the swift procurement of land and elimination of Indigenous territorial claim, Stevens would often placate tribal negotiators, assuring them that the treaties "secured their fish" (Ott 1987). Stevens responded to Indian concerns about the United States destroying their relationships to land, their social order, and their livelihoods, telling them, "you will be allowed to go to the usual fishing places and fish in common with the 
whites and to get roots and berries to kill game on land not occupied by whites; all this outside the Reservation" (Documents qtd. in Trafzer 2005, 404). That Puget Sound tribes signed on to these treaties was contingent upon these very provisions (CRITFC 1991).

Within thirteen months, Governor Stevens concluded ten treaties that transferred one hundred thousand square miles of Coast Salish and other Indigenous lands to the U.S. government in exchange for monetary aid held in trust, fiduciary benefits, recognition of tribal sovereignty, and usufruct land and water rights. The treaties established in the Puget Sound region included the Treaty of Medicine Creek with the Nisqually, Puyallup, Squaxin Island, and Muckleshoot Tribes; the Treaty of Point Elliott with the Lummi, Nooksack Stillaguamish, Swinomish, Upper Skagit, Suquamish, Sauk Suiattle, Tulalip, and Muckleshoot Tribes; the Point No Point Treaty with the Skallam, Chimakum, and Skokomish; and the Treaty of Olympia with the coastal Quinault, Hoh, and Quileuete tribes.

The transfer of territorial claim from Indigenous peoples living in these lands to the U.S. government marked "an epic regional drama" that restructured inter-tribal, international, and socioecological relationships (Harmon and Borrows 2008). Within a matter of decades, the new legal, spatial, and ecological transformations attendant with this transition of territorial claim created drastically new environmental and legal landscapes that betrayed what had for Coast Salish tribes been the centerpiece of the treaty agreements - the guarantee of continuing long-established relationships with nonhumans via food provisioning on and off reservations.

The terms of the treaties held the right of Native Northwest people to hunt, fish, and gather food "in common" with Washington State citizens. As Levitt Richards puts it, 
"many a treaty inscribed on parchment, signed and sealed with pomp and ceremony, has been broken or bent badly" (Richards 1991). Private land-ownership came with fencing that kept Native people off their provisioning sites, and farming compounded this loss and dispossession by transforming the landscape. Increasingly settlers became antagonistic toward Native Americans who continued their systems of food provisioning and relationships with the land as best they could under settler colonial rule and its attendant borders and geographies.

\section{(Un)Making Foodscapes and Terra Nullius in the Northwest}

The agendas of colonial agents engendered biases that shaped the ways settlers and settler knowledge producers understood precolonial landscapes, peoples, and humanland relationships in the North American Northwest. Highly anthropogenic and cultivated landscapes —including estuarine gardens, Garry oak savannas, camas prairies, mountain berry meadows, root gardens, shellfish gardens, tidal flats, and fulsome salmon fishery itself — became, in the eyes of Anglo-settler beholders, pristine Nature. The peoples here, in turn, became "hunter-fisher-gathers"-representatives of early-stage Man who merely grazed on Nature's bounty. On encountering southern Puget Sound, George Vancouver, the captain of a British expedition to the Northwest Coast of the Americas between 1791 and 1795, remarked on the expansive camas prairies dispersed between dense conifer forests. He described them as "beautiful," "delightful," "spacious," and "well stocked," wanting "only the assistance of art to constitute that desirable assemblage of surface [...] only to be acquired by an immoderate experience in manual labour" (Vancouver 1984, 
568). Vancouver's enthrallment with, and fundamental misrecognition of, these prairies as untouched nature - absent, and in need of, human labor — characterizes of a perception within U.S. settler society that continues to subtend the way it organizes its relationships with Indigenous people and nonhuman nature on what were, and still are, Coast Salish lands (ibid).

It is only in the last two decades that anthropologists, archaeologists, geographers, and others have begun to grasp that the people here employed complex land and water management techniques to produce a highly variegated network of food systems that supported a very dense population (Deur 2002). While some have taken this information to describe a kind of Indigenous agriculture, Kat Anderson rather articulates that the forager/agriculturalist divide instantiates a conceptual limitation imposed by European settlers and Anglophone thinking. She argues that this "dichotomous view of naturehuman interactions has shut out the fact that Indian groups across [the American West] practiced many diverse approaches to land use, and it has led to a focus on domestication as the only way humans can influence plants and animals and shape natural environments" $(2005,125)$. That "Indigenous peoples have been pigeonholed by social scientists into one of two categories, 'hunter-gatherer' or 'agriculturist,"' obscures the role of "many indigenous peoples as wildland managers and limiting their use of and impacts on nature to the two extremes of human intervention" (ibid).

The removal and containment of Native peoples for the sake of settlers' ability to convert the land into agricultural spaces of production that contributed to the growth of the nation-state, entailed not only the human violence attendant with displacement and dispossession, but abruptly new death-making regimes affecting a multitude of species 
and ecologies — perhaps most visible now in the form of the North Pacific salmon depletion crisis. It is a kind of recursive violence in terms of Indigenous survival —where the inability of Indigenous people to tend their lands results in further environmental change felt in the form of loss, which exacerbates barriers to intergenerational knowledge.

While the settler-state agenda in Washington State has always been to contain and assimilate with the ultimate goal of Indigenous elimination, Indigenous persistence of living according to prior socio-legal orders that involve particular relationships to nonhuman others has far out-lived what treaty initiators and reservation system organizers had imagined. This ongoingness is not only a matter of Indigenous survival, but itself exposes the still utterly hegemonic logics of settler colonialism, including the notion of settler-state inevitability, to be mythology. To the extent that the resurgence of Indigenous food practices or the success of legalistic fishing rights struggles grab the attention of food scholars and social scientists, it is cast as good for Indigenous people. Less noted is how it fundamentally interrupts settler colonialism itself, its objective of elimination, and its failure to achieve this because Indigenous people continue to insist on governing themselves and exercising sovereignties under a moment of empire, which both precede and supersede it (Simpson 2011, 211).

\section{Salmon and Fishing}

The decline in salmon populations concomitant with agriculture and industrial development began to rupture Coast Salish socio-legal relationships with fish already in the decades subsequent to the establishment of treaties. More immediately, Native fishers 
were quickly criminalized under settler jurisdiction and in relation to settler borders. They found themselves outside of fences erected by settlers around private landholdings marking off harvesting grounds. When they looked for alternative fishing places, settlers would accuse them of taking salmon in ways that were causing the stock declines (Leibhardt 1990).

Soon, Coast Salish people found themselves being policed on off-reservation fishing sites as the Washington Fish and Game department began regulating salmon in response to these declines. As people in settler society began to notice diminishing salmon returns, they paid little attention to the effects of salmon habitat degradation caused by damming, logging, agri-business or other industries and practices had on salmon. State agencies, rather, focused on overfishing as the problem, ushering in a host of new laws to regulate fishing. Without regard for the protections outlined in treaties for Coast Salish people to fish on ceded and unceded land in perpetuity, lawmakers and enforcers not only subjected Native people to these new laws and regulations, but often targeted them, maligning their practices, and scapegoating them for the declining stocks.

By the early $20^{\text {th }}$ century, tribal council meetings across Puget Sound were inundated with complaints in which fishers were arrested for violating the new fishing laws. Puget Sound tribes dedicated their speaking time at meetings for the National Congress of American Indians to how "the whites, particularly the officials of the fish and game departments of Washington State, were violating their treaties and harassing the Indian fishermen" (Deloria Jr. 1977, 1). Early on, tribes organized and invested what resources they had in seeking legal recourse to restore their mobility and sovereign right to fish at their accustomed places. As they maneuvered the legal apparatuses of 
the settler-state, Salish fishermen also refused to abandon these practices, risking arrest, police violence, confiscation of gear, and imprisonment (Lichatowich 1999).

Early $20^{\text {th }}$ century Progressive reformers like Theodore Roosevelt and Gifford Pinchot believed that rivers in the west "should be managed by experts who could use science, technology, and centralized planning to make the most efficient use of natural resources. In their view, it was best to use river water for agriculture instead of 'wasting' it by allowing it to flow to the sea, instead of allowing it to nurture the wild salmon" (Lichatowich 1999, 74).

In 1931, the [Bureau of Reclamation] contended that "agriculture made far better use of water than fish did" (Lichatowich 1999, 75). B. E. Stoutemyer, bureau's general counsel, said in a letter about irrigation in the Yakima River: "As there are about 100,000 people living in the Yakima Valley, all dependent on irrigation, I do not believe any serious argument could be made that the water should be taken from the farms and orchards to improve fishing conditions."

However, the mid-1960's marked a shift from enthusiastic resource extraction and the natural resource economy to the sobering recognition that these resources were being extracted in ways that could not be sustained, leading to the rise of conservation ethics and interventions (Dougherty 2014). As treaty fishing rights became entangled with this new emphasis on natural resource conservation and management, state agencies as well as settler citizens vilified Native fishing practices in new ways, deeming them antithetical to the science of conservation, even though "the treaty tribes' annual fishing harvest accounted for only a marginal amount compared to the fish reserved for sport and commercial fishing" (ibid). Federal Indian policy during this time, from the 1950's to 
mid-1960's, was defined by “termination," an assimilative policy that sought to incorporate American Indians into U.S. society, entailing the cessation of the government's trust responsibilities to tribal communities. State agencies and settler citizens increasingly viewed American Indians as an ethnic minority whose claims to rights to hunting, fishing, and other practices that did not accede to U.S. spatial boundaries had become excessive and obsolete.

\section{Plants and Land Tending}

When explorers and settlers began to enter the Northwest coastal regions of Turtle Island, they did not grasp that they were encountering a patchwork of tended, cultivated, and manipulated landscapes - most of which were managed as a foodshed. The plant and landscape management practices of Coast Salish people "range from relatively largescale (geographically) and long-term activities — such as the use of fire to clear prairies and subalpine meadows - to very focused actions, such as the pruning of individual shrubs" (Turner 2013, 107). Some of the most important cultivated food landscapes were sustained through low intensity anthropogenic burning, producing and sustaining meadows and prairies that provided for a wildly diverse diet of dozens of plants and animals. In terms of plants, some of the most prized, delicious, and nutritious foods maintained by these fire ecologies were the carbohydrate rich camas bulbs that are dug up with the root of the plant—harvested in spring and stored for winter use, and antioxidant rich mountain huckleberries.

While the treaties signed by tribes in now Western Washington have long been evaluated in court with regard to salmon fishery use and management, it has received less 
legal attention in terms of land management, even though the clause refers not only to fishing, but to gathering "roots" and "berries" and hunting "game." We have seen that in the first place the tribes who entered into negotiations with the U.S. government did so under duress, false pretense, and bad faith on the part of federal government representatives, and also that the guarantee to their food provisioning grounds constituted on of the most significant premises upon which these contracts were signed, at such a high cost to Native Northwest peoples. How Indigenous access and relationships to these places were quickly whittled down to mere fragments mirrors the struggle to continue to fish and catch salmon. It involved what must have been unimagined waves of settler encroachment, fencing off of private landholdings, ecological transformation through settler agriculture and related land practices, and, subsequently, urbanization, the establishment of protected areas, massive industrial pollution, and the impatient sentiment in settler society that Native people ought to have disappeared or assimilated by now.

Many of the root and estuarine gardens that Salish people tended had to be abandoned due to the sheer population losses resulting from colonial diseases like small pox and influenza, relocation, or because they were taken over as agricultural or grazing lands (Duer 2016, 149). Productive landscapes succumbed to succession without Indigenous management. In 1998, a Coast Salish person lamented in her conversation with a researcher that

You can't see [the garden plots] anymore. It's all overgrown with tall grasses, and all that....see, it's been looked after ... The last time I was there, I took a funeral party up there, and I told my son "Let's stop by there where we used to [have our gardens]." And there's nothing there. 
You can't even see it. You don't see them anymore, 'cause

I guess it's just like any other garden. If it's not looked

after, it's overgrown (Dick 1998, qtd. in Duer 2016).

The receding markers of cultivation only further reinforced the notion among settlers that these were wild lands requiring civilizational settlement and utilization (Duer 2016, 149).

\section{The Dawes Act: Re-Enforcing Agricultural Assimilation}

The Dawes Act, or General Allotment Act, reveals that settler colonization and its relationship with the agricultural ideal for humanness and citizenship was never simply an event, but a structure that informs continuous rounds of territorial theft. In the Northwest, like in other places, reservations constituted places where Indigenous people could continue to live according to their own (adaptive) social orders and ways of relating to the land. The Dawes Act not only worked to reduce already diminished Indigenous landholdings, but specifically targeted "the nature of Indian land ownership" (Schneider 2016). It divided the lands held in common by tribal groups living on reservations into individually owned allotments to managed by (heteronormative) nuclear households. This state-sanctioned assimilation policy sought to further contain and/or eliminate Indigenous people by enforcing a mode of living organized by private property reproduced at the level of the patriarchal nuclear family. By "giving" individual families these private landholdings, the geography of Native held land was reduced significantly. It disrupted social and socioecological life on reservations profoundly.

In light of the multifarious modes of genocidal violence experienced by Indigenous peoples in the Northwest, many have continually practiced, and fought to practice, their foodways, along with the intricate set of multispecies social relationships 
entailed by them. The legal battles and successes of Western Washington treaty tribes to fish and co-manage the fishery represent what many call the biggest Native American Rights successes in U.S. history.

\section{Tracing Anti/Colonial Enjambments}

\section{Food Sovereignty}

In the last 10-15 years, Coast Salish actors have worked to build a resurgence in traditional and decolonizing food practices, and within which "Indigenous food sovereignty" is being re/defined, linking up their particular history of struggle, refusal, resistance, and ongoingness to global anticolonial food politics. As they have done so, it has become clear that Indigenous food sovereignty in North America complicates any monolithic politics or definition of either "food sovereignty" or even anticolonialism. Part of the contribution this dissertation makes, outlined in the conclusion, is to offer one of the still rare ethnographies of Indigenous food sovereignty organizing in North America, and an analysis of how it complicates and reshapes "food sovereignty" as broader global social movement countering neoliberal globalization.

\section{Alternative Agriculture and Food Justice}

Geographers, anthropologists, and closely related social scientists attending to food and eating have in recent years generated a substantial literature questioning the inherent "good" of the local, sustainable agriculture movement that began to emerge in the US in the 1970s and has become increasingly popularized since in the 1990s (see Horst et al. 2017). The dominant lines of critique therein largely involve Marxian political economy and political ecology, critical race theory, and postcolonialism (see 
Darly and McClintock 2017). In a recent review of this literature, and its recent extensions into European scholarship, one can see how scant a settler colonial analytic exists here in that, in attempting to include it as part of which is explicitly being grappled with, the authors are only able to cite one article that does so- Sara Safransky's "Greening the Urban Frontier" (Darly and McClintock 2017). The extent to which Indigenous food sovereignty and/or Indigenous food and nutritional struggles are brought into this literature have mostly been through the lens of food justice (Alkon and Agyeman 2011), Marxian analyses of capitalism and the effects of the commodification of food (Trauger 2017), racial biopolitics (Slocum 2010).

This disarticulation led me to consider Eve Tuck and K. Wayne Yang's essay, "Decolonization is Not a Metaphor." In the article, Tuck and Yang grapple with the over and mis-use of "decolonization" as it is increasingly employed to describe social justice projects - whether aimed at achieving antiracism, fostering inclusivity in particular spaces, or critiquing patriarchy — that do not meaningfully work toward decolonization. Tuck and Yang argue that if a project is not dealing with the way settler colonialism circumscribes human-land relationships in specific places, it is not decolonizing. "Decolonization," the assert, "doesn't have a synonym" and colonization "is not an approximation of other experiences of oppression" $(2012,3)$. Treating decolonization as something can be tacked onto any liberatory project represents "settler fantasies of easier paths to reconciliation" $(2012,4)$. It is of critical importance, rather, to attend to "what is irreconcilable within settler colonial relations and what is incommensurable between decolonizing projects and other social justice projects" $(2012,4)$. They insist, rather, on "recognize[ing] incommensurability $(2012,4)$. It is this recognition that one is hard 
pressed to find within a North American Critical Food Studies literature where elisions between antiracist, anticapitalist, and decolonization abound. To insist on grappling with the incommensurabilities between these projects is not to suggest they are opposed.

In the cacophony of projects, visions, and politics organized on Coast Salish and other Indigenous lands on Turtle Island that have come to live under the sign "social justice," Indigenous dispossession of the lands that make them possible continue to be disavowed, despite and because of the ways "decolonization" is thought to be something that can be tacked on to any emancipatory politics.

In the next section I highlight how alternative food politics and practices in Washington State emerged out of the agrarian practices and logics that functioned as colonizing technologies of these lands. It is emphasizing this historical set of relationships, and not simply by comparing different politics, that we might begin to see the deep and troubling contingencies between what has become known as the alternative food movement in the U.S. and what is being articulated by Coast Salish and other Indigenous people as Indigenous food sovereignty—both happening on and seeking to transform "selfsame land" (Tuck et all 2014). Words and ideas such "local," "placebased," and "sustainable" hide incommensurability because Indigenous food sovereignty engages those concepts. Yet if we dig deeper, we see that the horizon for "relocalization," what it is entailed by being "place-based," and the environmental logics of "sustainability" carry different meanings for people differently positioned within US settler colonialism in ways that might be made more legible and thus, in turn, open new ways of organizing around the ways food connects and disconnects humans and other beings and forces. 


\section{The Roots of "Alternative" Agriculture in Washington State}

Washington State became the seat of a self-described "alternative agriculture" movement in the 1970's that has been influential not only in shaping what has in the $21^{\text {st }}$ century become a booming array of local, sustainable, and alternative food organizations and alternative food production/consumption projects that exist in Western Washington. The movement began with a group of homesteaders, activists, and food producers in the Northwest who became intensely interested in the work of Wendell Berry, the novelist, poet, political activist, and radical Christian thinker who wrote about the alienation of humans from the greater economy of the biosphere with the emergence of an industrial order (Bennet and Gowler 2012, 55). In 1974, this group of people organized a symposium in Spokane, Washington titled "Agriculture for a Small Planet," featuring Berry as a panelist and speaker. A directory of the conference includes the names of people who went on to shape the region's local, sustainable agricultural scene, including Gene Hahn, founder of Cascadian Farm, Darlyn Rundberg, who organized the Seattle's first P-Patch garden, and Sam Benowitz, who founded Raintree Nursery, and several leaders who shaped the organic and sustainable farming programs at Washington State University (Denn 2017). One of organizers, Mark Musick, described how he and others were profoundly moved by the way Berry described the "loss of the traditional farm economy," exhorting "if we allow another generation to pass without doing what is necessary to enhance and embolden the possibility of strong agricultural communities, we will lose it altogether" (Musick 2008). That year, Musick and his colleagues arranged a "regional network of organic farmers and gardeners in the Pacific Northwest" under the 
name Tilth. Musick affirms that the "goal for the Tilth Association was to bring together organic gardeners, rural homesteaders, consumers, and environmentalists - that broad 'constituency for a better kind of agriculture"' (ibid).

Mark Musick is now recognized as one of the formative "pioneers" who has shaped Seattle's local, organic food and farming landscape. Prominent chef Bruce Naftaly gushes that Musick "sowed all the seeds; he cultivated the ground for the area" (Denn 2017). Now called the Tilth Alliance, this organization not only persists but continues to be the hallmark sustainable food organization in Puget Sound and the broader Northwest, with a chapter in Seattle that is highly integrated with the social life of the city. Tilth oversees organic certifications, farmers markets, educational farms, and organic farming programs, and networks with dozens of non-profit organizations, activists, community organizers, food producers, and consumers committed to advancing this agrarian vision.

Their work has influenced a multitude of alternative food projects flourishing in Western Washington. Among the most visible, impactful, and widely networked organizations, the Washington Tilth Association has its headquarters in Seattle. This extensive regional network of organic farmers and gardeners describe their mission as a "group of idealists in Washington State" with "the desire to 'get back to basics,' [...] willing to put their ideals to the test in pursuit of 'real,' back to the earth farming" in the Pacific Northwest" (Musick 2008). Seattle Neighborhood Farmers Markets began in 1993 with the founding of the University District farmers market, growing to include six major farmers markets in different neighborhoods of the city. They express a commitment "to supporting [..] Washington's small family farm businesses provid[ing] 
$[\ldots]$ direct sales sites for our region's small farmers, while also educating consumers about local farm products and the importance of [...] preserving local farmland" (ibid.). Puget Sound Fresh, another network of farmers markets, state that "[they have] served to raise awareness of the numerous economic, environmental and health benefits of local agriculture" (ibid.). There are a number of working urban farms in and around Seattle, Tacoma, and Olympia espoused to the idea of local, sustainable agriculture as a means of addressing the environmental and social problems produced a globalized food system dominated by industrial agriculture. The types of successes lauded by these organizations include that "there are 120 farmers markets in Washington, with 34 in King County alone, with total sales estimated at $\$ 41$ million, and that Washington's certified organic acreage has grown from 6,200 acres to 78,000 " (ibid.).

It becomes clear quickly that ideas about food system change involve an imagined horizon for re-localization defined by white, agrarian settlement. That there was any history of land use that sustained resilient ecosystems while supporting dense human populations with a highly diverse diet seems to be pre-erased by agrarian goals for healthy human-land relationships.

While the practices and politics of this network of alternative food actors have diversified somewhat with the substantial growth of this movement over the last several decades, localism and agriculture continue to constitute its predominant motifs. Most of these organizations have focused on developing urban farms and agricultural production, proliferating farmer's markets, developing community supported agriculture networks (CSA's), expanding and protecting farmland, and supporting small farms that use less chemical and synthetic inputs, and whose food travels few miles from "farm to table." 
There has also been an increase in the focus on "food justice" in Seattle and urban Puget Sound. Organizations and individual actors emphasizing food justice in the region have prioritized efforts to establish urban farms in low income communities and communities of color. These projects often seek to find ways to use local agricultural food production as an intervention in the lives of vulnerable and under-privileged youth, or to generate self-sufficiency and economic self-reliance for racially marginalized immigrants.

Endeavors like revitalizing camas prairies in Puget Sound, or collaborating with tribes to reintroduce controlled burning to manage berry meadows in the Cascade Mountains, have not figured at all as important food system or land tenure measures in the alternative food movement built in the Northwest. Nor do sustainable food actors or environmental organizations in settler society always make ready allies with tribes asserting their treaty rights to co-manage the salmon fishery. Not infrequently, they end up on opposing sides of policymaking battles with regard to salmon resource management. Yet these are matters of paramount importance for most tribes and Indigenous food sovereignty actors in Salish Country.

Mostly the alternative food movement simply ignores Indigenous histories, presents, and futures on the land as they seek to indigenize themselves to it through local food provisioning. It is safe to say these are not malicious efforts on the part of settlers to exclude or further erase Native people from their homelands, but rather that there is an inherited logic about agriculture as a righteous mode of land use that is ultimately premised on erasing Indigeneity. 


\section{Settlers as Desiring-Machines Desiring Land}

In tracing the history of the role of food and agriculture in colonizing Coast Salish lands, I have sought to bring out how this history has worked not simply as an event with social and environmental leakages we might call a "legacy," but rather the production of a structure organized around land. I want to highlight here that Indigenous dispossession is not only a fiat accomplished by way of settler-state officiates (military, politicians, police), but is also something produced and maintained by settlers. Discussions about what defines settler, and its relationship to other categories (e.g. native, arrivant, migrant, slave, member of a diaspora) are only beginning, raising extremely challenging questions and pointing to new directions for solidarity and emancipation, and particularly in the domain of food system politics. Eve Tuck and K. Wayne Yang warn that

[A]lthough the setter-native-slave triad structures settler colonialism, this does not mean that settler, native, and slave are analogs that can be used to describe corresponding identities, structural locations, worldviews, and behaviors. Nor do they mutually constitute one another. For example, Indigenous is an identity independent of the triad, and also an ascribed structural location within the triad. Chattel slave is an ascribed structural position, but not an identity. Settler describes a set of behaviors, as well as a structural location, but is eschewed as an identity. (Tuck \& Yang 2012, 7).

Building on some of their recent work, I suggest one way of thinking the category of settler and its relationship to settler colonialism is to borrow from Deleuze in order to conceptualize settlers as desiring machines plugged into the assemblage of the settler nation-state, which desires territorial acquisition for the sake of comfort, wealth accumulation, enacting humanistic utopias, and which requires rendering labor-providers and prior inhabitants of the land "ungeographic" in particular ways (see Tuck et al. 2014). 
It is critical to see that settler colonialism entails not merely an Indigenous-State relationship, but a structure reproduced by settlers desiring equality, liberty, wealth, and/or security on stolen Indigenous land. The waves of encroaching settlers who raised gardens and farms, who put up fences, who express intolerance with Indigenous people continuing to relate to the land in ways that are supposed to Progress into agrarian cultivation, played perhaps the largest role in how Coast Salish people became dispossessed of enormous swaths of land, from their relations with numerous species, in many ways with each other and their own bodies and physical well-being. This, I think, instantiates what Jodi A. Byrd means when she asserts that settler colonialism ought not to be conceptualized as a "vertical Hegelian master-bondsman dialectic struggling for dominance and territoriality" but rather, "a horizontal grasping network of relational and precarious dispossessions that enable dispossession to continue in perpetuity" (Byrd 2016). This ought to deeply trouble the way that food justice and food sovereignty scholars and activists tend to position those who invoke these political concepts in North America, whether Indigenous people or settler farmers, as necessarily working toward the same future, even if both challenge a neoliberal food regime and/or the structures of race it reproduces. 


\section{CHAPTER 3: Plant People and the "Cacophonies" of Settler Agro-Localism: Indigenous Land Pedagogies and Urban Agriculture's Geographies of Disavowal}

Tolerance, recognition, and the specific technique that is multicultural policy are but an elaboration of an older sequence of attitudes toward "the problem" of difference on acquired, some might argue seized, territories.

Audra Simpson

Whatever settlers may say-and they generally have a lot to say, the primary motive for elimination is not race (or religion, ethnicity, grade of civilization, etc.) but access to territory.

Patrick Wolfe

We stood in front of a winter bare alder wood in a peri-urban neighborhood of south Olympia. Gathering us here, Elise rehearsed a story Skokomish Elder Bruce Miller shared with her years ago. When he was a boy, his grandfather brought him to a place like this and asked, "What do you see?" He answered, "trees." Anticipating this response, his grandfather rejoined, "That is what someone from your generation might say. People from my generation would say they see many nations standing together." There were sixteen of us standing behind a farmhouse operated by a prominent local/urban agriculture and food justice organization called Garden-Raised Urban Bounty (GRuB), teaching or being introduced to Coast Salish pedagogies about the land and its politics. I had been invited to co-develop a curriculum for Native and regional youth with this collaboration of Indigenous and settler food actors. It would focus on plants and cultivated plant landscapes tended by Coast Salish people throughout deep-time histories up to the present, and how the people who find themselves on the Indigenous lands spanning the western slopes of the Cascade Mountains to the Salish Sea can tend to and be tended by them in the present and future. The result would be a teaching toolkit that 
could be used in public and tribal schools as well as other educational institutions across Washington State, called Tend, Gather, and Grow (TGG).

The Puget Sound region and its urban centers - Seattle, Tacoma, and Olympiahas received its fair share of scholarly attention within the urban agriculture, food justice, and sustainable food movement literatures due to its proliferating network of alternative food production and provisioning projects stemming from the area's "dissident agriculture" movement of the 1960's. A survey of that scholarship reveals a notably tenuous connection with longstanding and renewed struggles for Indigenous food sovereignty in this region—spanning a burst of activity around Coast Salish plant knowledge, cultivation, and harvesting grounds in the last 10 years to Northwest treaty tribes' legal struggles around fishing rights spanning the entire $20^{\text {th }}$ century and that continue to shape the state's entrenched environmental politics of salmon restoration. When I first arrived in Puget Sound, I wanted to better understand the extent to which the separateness of Indigenous-settler/arrivant food politics and their attendant environmental projects are shaped and reproduced by settler colonial technologies and geographies.

Tend, Gather, and Grow brought Coast Salish traditional food revitalizers and Indigenous food organizers into a sustained collaboration with a celebrated urban agriculture and food justice organization, creating a space to observe the "points of connection that are brining Indigenous peoples and settler food actors into dialogue, negotiation and solidarity building" and how those relationships are "complicated by the power asymmetries that continue to shape Indigenous-settler relations" within the U.S. settler-state (Daigle 2017). 
In this chapter, I draw from my participant-observation with Tend, Gather, and Grow to examine the dynamics between Coast Salish food sovereignty actors and a celebrated food justice/urban agriculture organization in Olympia, Washington, drawing conclusions that think with Jodi A. Byrd's concept of "cacophony" alongside scholarship on urban Indigenous land pedagogies as a decolonizing intervention to settler place-based environmentalism. First, I mapped out the divergent but related food politics lineages that have come to the table at TGG. This allows me to examine implicit tensions, some incommensurable, with regard to how the relationships between people, place, and the land are imagined, and what justice entails with regard to diversity, land, place, and food. I trace changes in how staff at GRuB narrate human-land-place relationships as a result of their sustained engagement with Coast Salish foodways revitalizers, whose politics of resurgence and refusal confound settler land and nature logics, which I argue are inherent to agrarian progressivism and food-centered social justice projects. Rather than merely revealing underlying conflict, I attend to the sociopolitical and philosophical possibilities that become more visible as incommensurable orientations to justice collide (or diverge), specifically the futurities entailed by "re-storying" human relationships to land as Indigenous, whether urban and/or currently ceded territory or not (cf. Bang et al 2014). To do this, I draw from scholarship that identifies science, place-based, and environmental education as "critical sites of struggle" where settler colonial logics are “quietly buried” (Bang et al. 2014, 2). 


\section{Stinging Nettle Stories: Allusions to Incommensurability in Food-Based Solidarity Work}

Nettle is an herbaceous perennial native to present day Western Washington. A prickly sort, its deep green leaves are toothed along the edges and armored with small hairs that secrete formic acid when it bristles against skin. Nettle is notorious for its tendency to sting those unfamiliar with this plant. The pain of a nettle sting has earned it a reputation as a nuisance among those who seek out and curate nature experiences in the Pacific Northwest - city land managers, hikers, gardeners, food foragers, and private land owners. In residential areas, public parks, and urban greenspaces it often gets mowed down in favor of the "classed aesthetic" of a sheered lawn (Robbins 2003), or to promote other plants deemed less weedy and dangerous. Yet nettle returns willfully in disturbed habitats, and Coast Salish plant lovers, knowledge keepers, and food revitalizers highly value and eagerly seek out this plant to harvest its micronutrient-dense leaves in verdant areas in and surrounding Seattle during late winter and spring.

Our meetings as co-developers of TGG began in early March of 2016, when nearly everyone in the group was excited about the emerging nettles across Puget Sound. Many of our team members had already begun to harvest nettle leaves in Tacoma, Olympia, and Seattle. They each seemed to have their own personal nettle geographies in and around these cities. This well-loved plant was one of the first we began to discuss, taste, ingest, philosophize, learn from, and create lessons around together.

Valerie Segrest calls nettle her first plant teacher. She is a Muckleshoot tribal member and Native foods educator who works with tribal communities throughout western Washington. Valerie's involvement with TGG marks one of many projects over 
the last decade through which she has collaborated with Elise and a number of others who came on as team members, including Elizabeth (Spokane), Mariana (Yakama), Aleta (Squaxin Island), Charlene (Aleut). She expresses that everywhere she goes, she hears "stories about the ways Native foods heal people. Elders remind me that problems like diabetes and heart disease were almost nonexistent in our communities until we began to lose access to foods like salmon, huckleberries, elk, and wild greens" (Segrest 2013). Valerie makes a point to clarify that it is in this context that nettle fortifies her-as "living link" between her ancestors, the land, and herself, not as part of an "organic diet." Valerie, who holds a Master's Degree in Nutrition, understands intricately the repertoire of concerns and critiques put forth across the gamut of alternative food activism, particularly as they are leveled against a global food regime dominated by industrial monoculture. These critiques certainly motivate her own food politics in many ways. At the same time, Valerie is clear about asserting her work in terms of tribal food sovereignty — something which foregrounds a range of socio-political and socioecological dynamics that are elided in U.S. alternative food politics, and that link up with the global food sovereignty movement in ways that require ongoing elaboration and qualification. Valerie has built her food politics very explicitly around the framework of tribal (also Indigenous) food sovereignty, in response to a set of needs and assertions in relation to the political sovereignty, self-determination, persistance, and well-being of Coast Salish people and lands in relation to U.S. settler colonialism. Valerie qualified that she understands the effects of nettle on her body in relation to violated linkages between Coast Salish people, lands, and its non-human political and agentive constituents, and not simply about having access to healthy, organic food. This is exemplary of the kinds of 
utterances, assertions, and interpositions that I became attuned to over 18 months of participant-observation among Indigenous and non-Indigenous food actors in south Puget Sound. I began to take note of the more and less subtle ways Valerie and others, in their collaborations with non-Native food and environmental actors, would disrupt or otherwise gestured to aspects of non-Native environmental practices or imaginaries, revealing tensions, conflicts, or incommensurability with the decolonizing work of Indigenous food sovereignty. At first, I understood this as how tribal food sovereignty actors raise unsettling questions about who gets to define, what is erased by, which sociopolitical/socioecological worlds are (re)produced by, and what futures are secured (or not) through alternative food system work. Eventually, it became more legible to me that these interpositions, more pointedly, refused dreams of progress and transformation bound up with land ontologies rooted in terra nullius.

\section{Geographies of Justice and Disavowal in South Puget Sound Urban and Local}

\section{Agriculture}

\section{Garden Raised Bounty}

Our conversation about nettle in late March took place at GRuB's farmhouse in Olympia, built in 2008 on 2 acres of land. I quickly learned that GRuB would house TGG physically and institutionally. The owners of this two-acre parcel donated their land to the organization in 2006, after having allowed GRuB, and its organizational antecedents, to use their private land over the previous 10 years to implement a set of programs focused on "bringing good food to all people" (Piliaris 2007) through engagement with small-scale farming and gardening in the city. The farmhouse, and 
its surrounding gardens and 1.5-acre farm, served as the main meeting spot for TGG's bi-monthly meetings over the next months.

In the process of creating TGG, Elise Krohn reached out to Kim Gaffi, GRuB's Director of Programs, to establish a foundational partnership that would allow for a widereaching implementation of this place-based, food-centered project. GRuB is an established community-based 501(c)3 non-profit organization located in Olympia, Washington that has developed partnerships over the last 15 years with local public schools, offering programs through which students can receive educational credits as well as financial support and job experience by learning to grow and distribute food from the farm. Elise highly regarded the way Kim Gaffi's work at GRuB focused on empowering young people and helping them to benefit from and become citizens of their own food system. By developing TGG out of a partnership that married GRuB with Elise's longtime work as a Coast Salish food and plants revitalizer, she formed an alliance between two forces with distinct food activism lineages, and that offered GRuB a new and far-reaching set of partners, learners, social networks, and institutional support systems. Elise planned TGG in way that would allow its work to expand over time, reach a wide and diverse audience while committing foremost to tribal sovereignty and the well-being of Indigenous communities, and to be impactful long into the future at the regional level.

Garden Raised Bounty, formerly Garden Raised Urban Bounty, or GRuB, formed in 2001 out of merger between two grassroots alternative agriculture and local food programs-The Sister Holly Garden Project and the Kitchen Garden Project. The former focused on "garden-based educational opportunities to youth and seniors," and the latter 
on "providing low-income people with productive vegetables gardens" (Rains and Umholtz 2016, 303). In joining these projects under the name GRuB, its members began to expand these programs, broadening the scope of its mission toward inspiring "positive and personal community change by bringing people together around food and agriculture" and partnering with low-income people to "build a just and sustainable food system" (ibid).

GRuB members describe the organization as a sustainable/urban agriculture and food justice organization. Its participants deploy these terms as the centerpieces of their work and mission, and constantly build on and refer back to them through agrarian metaphors and inclusion-minded language. As alternative food activist leaders, they are both clearly influenced and oriented by these paradigms of food politics, and act as thoughtful, well-informed, contributors to alternative food discourses, elaborating the meaning of these terms for wider publics through essay-writing, online content, conferences, and interviews with local media.

GRuB describes itself as focusing on "small-scale sustainable agriculture." Their 1.5-acre farm exists at the center of their work. Staff, interns, volunteers, and high school students grow more than 14,000 pounds of food here annually, which is distributed to people through a number of localized producer-consumer networks that represent the typical practices of sustainable and urban agriculture praxis. Namely, GRuB sells its produce at a farmer's market stall, operates a farmstand on its property, offers community supported agriculture (CSA) shares, sells to local businesses and schools, and donates a portion of their produce to a food bank (ibid). They describe GRuB's mission as inspiring "positive personal and community change by bringing people together around food and 
agriculture" while bridging "the fields of agriculture, education, hunger-relief, leadership development, health care, and sustainability" (Rains and Umholtz 2016, 303). They are part of a broader urban agriculture and food justice movement promoting the expansion of agriculture to non-traditional areas as a means of addressing chronic hunger and its relationship to poverty, environmental degradation, as well as a range of social justice issues by being inherently inclusive and breaking down barriers to food access (Snyder et al. 2016 ix).

GRuB has historically focused on youth intervention as a way of meaningfully addressing what they identify — in alignment with the broader food justice movement —as a set of intersections between social injustice in U.S. society and the larger food system that especially turn on structures of race and class. GRuB points to a correlation between growing wealth disparity, hunger, and Adverse Childhood Experiences (ACEs) that generate "cycles of poverty, inequality and oppression" (Rains and Umholtz 2016, 304), and seeks to break this cycle by offering "agriculture-based employment training and drop-out prevention programs that engage local teens in land and community-based projects" (ibid). Thus their work focuses on youth programming that brings students and teens onto the farm.

GRuB developed a year-long program for low-income, out of school, and/or at risk youth called the "Cultivating Youth Employment Program" (CYEP), which they also call "GRuB School," and occasionally, "food justice high school." Part of the intention of the program is to link experiences of food insecurity with struggles in the domains of education, economic success, and health, and to reduce those challenges in the short term. Once enrolled, students learn about sustainable farming over the period of an academic 
year-how to grow vegetables, cook their own produce, build gardens, and run a farm. By supporting the short-term goals of drop-out prevention and job training through CYEP, GRuB hopes in the long-term to help build a generation of people with the capacity to "build a more just world" (ibid).

GRuB developed the program around three "core" pillars: "Farming Land, Farming Self, and Farming Community" "Farming Land" emphasizes introducing students to small-scale, ecologically-minded farming. As an immersive opportunity, it aims to provides job experience, expose them to the value of interacting with the land, and connect them with where their food comes from. The hands-on component of the program is complemented by a science-based curriculum focused on horticulture, botany, and soil science (Rains and Umholtz 2016, 306). GRuB worked with the Olympia School District to offer students academic credit through a cross-crediting process. "Farming Self" expresses the program's commitment helping youth achieve personal development by providing a space where they feel empowered as individuals and community members, and to work on their unique issues. "Farming Community" emphasizes the program's community service/responsibility aspect. To achieve this, GRuB plans interactive opportunities with other farms, volunteer organizations, and other local civic projects.

The program proved to be popular. More than 90 students from Olympia High School signed up for the program the first year, vastly outnumbering the 35 spots GRuB had the capacity to offer. In response, Olympia High School developed their own agriculture-based programing based on GRuB's model, calling it "Freedom Farmers at Muirhead Farm," and other schools in Thurston County have come to GRuB seeking to 
implement this model. In addition to spearheading and offering this kind of programming, GRuB also connects with hundreds of additional young people each year through a visiting and field trip program it refers to as "young roots."

GRuB holds up its agriculture-based education work and involvement with the broader community through its farm as an example of "what a vibrant, healthy, just food system can really look like" (Rains and Umholtz 2016, 315). What is invoked when GRuB staff refer to a "just" food system can be gleaned from the discourses they employ, the land use and community projects they implement, prioritize, and promote as an alternative to prevailing systems that work to render some people disempowered, marginalized, and food insecure.

\section{Mapping (Food) Justice in GRuB's Politics and Land-Based Practice}

In critically examining GRuB in this section, I both draw from and seek to complicate the way geographers and anthropologists have critiqued North American urban agriculture and food justice projects. In recent years, this area of scholarship has troubled otherwise widely lauded (within agrarian studies and across the popular press) food-centered social and environmental activism along several lines critique (McClintock 2017). I am particularly interested in engaging two. One prominent subset of the North American critical food studies literature draws from especially from Marxian political economy to illustrate how a range of food practices held out as "alternatives" to the neoliberal global food regime in practice instantiate and expand neoliberal governancewhether by simply creating new niche markets where environmental and social responsibility become "added value" to global food commodities, or through practices 
that at best mark out small spaces circumventing a broader political economy without reforming or transforming the institutions that produce the social and ecological crises these movements seek to address (Besky 2013; Guthman 2011; Holt-Giménez 2011; West 2012). Julie Guthman argues, rightly, for example, that by finding the solution to the failures of the prevailing food system in carving out small spaces of "alternative" and consumption and production networks, this activism ends up displacing the responsibility of governments, regulatory bodies, and transitional institutions to address poverty, hunger, and landlessness exacerbated by structural adjustment programs, neoliberal trade policies, and state/industry processes of accumulation by dispossession (2012).

A second subset builds on theories of race and racism (critical race theory and Deleuze-inspired "new materialism" of race) to reveal an unacknowledged "cultural politics of whiteness" through which alternative food activism inadvertently replicates Whiteness spatially, culturally, institutionally, even as its practitioners seek expressly to benefit and be inclusive of non-white populations (Guthman 2008; Slocum 2011). Some of this work illustrates the way sustainable, urban agriculture, and food justice projects exclude non-whites through unacknowledged spatial practices, cultural codings, and economic prohibitions (Alkon and Ageyman 2012; Guthman 2007; Slocum 2011). Some of this work looks critically at the determination to "bring good food to others" in urban neighborhoods under the banner of food justice (Alkon 2007; Guthman 2007), and the whiteness of alternative foodspaces and practices, such as farmer's markets, community supported agriculture (CSAs) (Allen 2004; Slocum 2007; 2011), and farm-to-table restaurants. 
What I will want to illustrate through my critical examination of GRuB — its landbased practices and imaginaries and its politics of difference and liberation — is, for one, that both of these lines of critique fail to get at how or why a project like GRuB becomes incommensurable with Indigenous food sovereignty at multiple points. Secondly, while, GRuB both aligns and diverges with them, foundational assumptions carried by these lines of critique themselves do not automatically cohere with, and in some ways negate, Indigenous futurities and sovereignties.

GRuB typifies food justice activism in that it foregrounds and seeks to confront the way the prevailing system of food production, distribution, and consumption perpetuates viscous cycles of "fatal power-difference couplings" (Gilmore 2004) that its practitioners articulate in terms of "social in/justice." The framers of food justice-a relatively recent food movement paradigm emerging in the milieu of US social movements and environmental politics — built on environmental justice scholarship and activism to put forth a more radical alternative food politics. Environmental justice links environmentalism and environmental policy to theories of justice and antiracism, limning the pathways through which environmental burdens and benefits are unevenly distributed socially and spatially. The intervention food justice makes into sustainable agriculture's reformist and oppositional critiques of industrial agriculture resides in foregrounding the way social-structural inequities are co-constitutive with the environmental perils of this food system. In defining and explicating food justice, scholars and activists describe it as a more radical food politic in that it seeks something more transformative than the reformist, consumer driven (vote with your fork!) politics that advocates of organic farming have popularized. I submit for all the ways food justice has sought to break with 
or reform sustainable agriculture and organic farming, it has largely held onto what Julie Guthman calls "the agrarian imaginary," centering while reimagining farming as an emancipatory and righteous spatial practice.

In one of the seminal works outlining what food justice means as a politics, Cultivating Food Justice: Race, Class, and Sustainability, Alison Hope Alkon and Julian Agyeman assert that "many low-income neighborhoods and communities of color have been systematically deprived of access to [the kind of] healthy and sustainable food" that sustainable agriculture advocates ask consumers to contentiously purchase to create the demand for organic production (2011). Food justice, for them, constitutes a way to refocus the efforts of alternative food activism toward "agricultural and land use policies that systematically disadvantage Native American, African American, Latino/a, and Asian American farmers and farmworkers; access problems in both urban and rural areas; [and] efforts to create sustainable local food systems in low-income communities of color"-in short, to achieve "a just and sustainable agriculture" $(2011, \mathrm{v})$.

One can easily catch sight of this framework and its foci in GRuB's work. It holds a 1) a commitment to justice, 2) in reference to marginalized and disadvantaged groups in the U.S., 3) largely by way of addressing issues of access to healthy food 4) produced via sustainable agriculture. Within this framing, I point to something in Alkon and Agyeman's edited volume that is echoed in GRuB's work. In their introduction to the concept of food justice as excerpted above, Alkon and Agyeman list Native Americans among a set of racialized groups who are "systematically disadvantaged" by "agricultural and land use policies." With regard to Native American food struggles, is this what is at stake? Is it that Native Americans constitute another racialized group within the U.S. who 
are disadvantaged by policy, and in need of greater equality under the liberal U.S. nationstate - a matter of U.S. liberalism making good on its promises? Read alongside Jodi A. Byrd's sweeping critique of how U.S. politics and social science collapse Indigeneity into racial Indianness, it becomes clearer that the the nature and political stakes of Native American food struggles transcend Alkon and Agyeman's definition of food justice as a politics. Byrd's work makes legible that some of the assumptions that go into food justice can themselves function as a kind settler technology — the rendering of indigeneity as a kind of ethnicity or race demographic. There's a profound displacement that occurs through collapsing Indigeneity into race/racism this way, obfuscating "the ways the existence of the United States depends upon the remaking of Native lands as its 'domestic' space while renarrating this legacy of foundational violence as the potential for antiracist inclusion of Indians into the nation as citizens" (Rifkin 2012, 139).

Scholarly critiques of food justice projects in anthropology and geography generally identify the trouble by gaging whether the outcomes live up to the group's own vision of justice and/or antiracism. Less commonly have anthropologists or geographers pointed to the need to unpack food movement's theories of justice in the first place, specifically to grapple with at what points social and environmental justice become competing or incommensurable with decolonization—something obscured by the way social justice projects have come to co-opt this term such that colonization is assigned to the racialized body (cf. Tuck \& Wayne 2012).

As GRuB has increasingly worked with Native communities in Western Washington, it is telling to consider how its members articulate these collaborations in terms of their broader politics. Almost a year into our work, Donald Trump was elected 
to the presidency — something that loomed heavily in our first meeting after it happened.

Otherwise obscured divergences in the spectrum of our group's political orientations surfaced in our conversation that day-for example, in exchanges between a white ethnobotanist among us upset by Hillary Clinton's loss, and other members, including a white woman and male member of the Iowa Tribe of Kansas and Nebraska who felt Clinton to be part of a political apparatus who Americans would hopefully become more critical of in the wake of a Trump Presidency. In the months after Donald Trump was elected President, GRuB released a statement from which the following is an excerpt:

We as staff are deeply affected by the historical oppression of our own families, friends, and fellow community members, and do our best every day to bring people together and to build community where we "cherish our similarities and unique differences." White supremacy, classism, sexism, homophobia, and other forms of oppression have no place in the community we envision.

The hateful rhetoric and violence being explicitly and openly directed at black and brown, native, LGBTQIA, Muslim, Jewish and immigrant communities across this country and the deadly violence recently in Charlottesville is a direct threat to many people who work at GRuB, volunteer here, donate here, and have participated in our programs. This white supremacist hate and violence is not new. Our country was built on the backs of those who were not seen as white.

This statement highlighted to me the way GRuB straddles a kind of liberal-multicultural politics and a more radical antiracist politics. The authors of this statement rightly point out that this country is founded on white supremacist violence. It also epitomizes what Eve Tuck describes as "liberal renderings" of social justice projects that tend to generate "an almost list-based approach" to injustice—-something that has been called "attending 
to the -isms $(2018,6)$. Again, Native people are listed among other disenfranchised groups relative to "white supremacist hate."

Compare this with the solidarity-messaging coming out of Native activism across the U.S. in the wake of Trump's "travel ban," a thinly veiled attempt to police and refuse entry to Muslim people at U.S. borders. A member of the Coleville Tribe attended the near-spontaneous protests at the Tacoma-Seattle Airport with a sign reading, "You R on Native Soil! I stand with the Lakota@ Standing Rock. Black Lives Matter! Native Lives Matter. We $<3$ our Muslim Brothers and Sisters." His message, connecting the immigration policy of the U.S. settler state and institutional racism to Indigenous presence and dispossession on those lands, was not isolated. Native people from an array of Indigenous territories organized the messaging "No Ban on Stolen Land," a moving and provocative show of solidarity casting U.S. border-policing as both violent and illegitimate. These messages diverged with a sentiment propounded many settler and arrivant protestors also performing acts of solidarity—namely, that "we are all immigrants." Nick Estes from the Lower Brule Indian Reservation in South Dakota described it as "a very jarring experience for a lot of Native folks" to experience travel ban protestors singing “This Land is Your Land” (2017). While GRuB's statement does not assert that "we are all immigrants," its "list based approach" to defining injustice, something to which Native people can simply be added, suggests a vague need for the U.S. to live up to its liberal promise of equality vis-à-vis white supremacy. It thereby rehearses an erasure of the geopolitics which constitute the condition of possibility for the U.S. settler-state's various death-dealing regimes_-such as racialized hunger and malnutrition. 
Like many food justice projects, GRuB activists strongly link this notion of justice to agriculture, specifically small-scale, organic farming —in a way that clearly comes out of the history of the alternative agriculture movement in Washington State and the U.S. more broadly since the 1970's. While GRuB has expanded its work and its engagement with communities across south Puget Sound, historically its work focuses on sustainable farming as an empowering praxis through which to build healthier, more just communities and to mitigate the material impacts of entrenched structural inequalities within the U.S. Throughout its core programs and education literature, GRuB employs agriculture metaphors (e.g. its tripartite: "farming self," "farming community," and "farming land"), suggesting the extent to which GRuB inherits what critical food geographer Julie Guthman calls "the agrarian imaginary" (2004). Guthman puts forth this term to limn how the U.S. alternative food movement imagine a more just and sustainable future by way of invoking a discourse and set of values that are traceable to $18^{\text {th }}$ century Anglophone colonial discourse, "in which working the land for oneself and one's own kin is an inherently redemptive exercise" (Besky 2013, 30; cf. Guthman 2004). Agrarian labor is infused with a sense moral redemption and cast as a righteous human-land relationship. Guthman uses the agrarian imaginary to reveal the movement's appeal to what is a whitewashed rendition of U.S. agricultural history scrubbed of its foundation in racialized land exclusions and Indigenous dispossession, which have left a legacy of racialized land-labor relations at every level of the contemporary food system. Within Guthman's work, however, Indigenous dispossession remains something that happened in the past, serving as precedent to modes of racism to which she attends rigorously and insightfully. Still, it remains for her notion of the agrarian imaginary to be examined as a 
settler technology through which settlers (a structural, not racial, identity) continue to see Indigenous lands as empty — a blank stage for utopian social projects.

GRuB's liberal/radical conceptualization of justice and its concomitant agrarian imaginary instantiate Byrd's assertions that progressive and transformative activisms seeking to "provisionally include those people othered and abjected from the nationstate's origins," instead engender "a cacophony of moral claims that help to deflect [this] activism from dismantling the ongoing conditions of colonialism that continue to make the United States a desired state formation within which to be included" (ibid). The notion of "cacophony" allows Byrd to describe "discordant and competing representations of diasporic arrivals and native lived experiences $[\ldots]$ that vie for hegemony within the discursive, cultural, and political processes of representation and identity that form the basis for what Wendy Brown has identified as the states of injury and Foucault and others have termed biopolitics" (Byrd 2011, xiii). Having examined GRuB in this way, it appears implicated in Byrd's assertion that

Any notion of the commons that speaks for and as indigenous as it advocates transforming indigenous governance or incorporating indigenous peoples into a multitude that might then reside on those lands forcibly taken from indigenous peoples does nothing to disrupt the genocidal and colonialist intent of the initial and now repeated historical process.

It becomes incumbent upon settler food actors participating in projects like GRuB to revisit and redefine their ethics, politics, and settler futurity-enacting land practices.

In subsequent sections of this chapter, I will highlight how these underlying dynamics play out in GRuB's intimate collaboration with Coast Salish food actorstensions that surfaced and transformations that are produced (or not) through that 
interaction. First, I will outline how the food practices and land pedagogies into which Coast Salish food actors enroll GRuB are decolonizing. I will finally offer concluding thoughts about what to make of the underlying contingencies entailed in this collaboration, and how a settler colonialism analytic shifts what a (food) politics of restoration, livability, and justice for heterogeneous life on Coast Salish and other Indigenous lands means.

In tracing the relationship between agrarianism, settler colonialism, and Indigenous dispossession, my intent is not to "expose" how urban agriculture projects like GRuB are agents of Indigenous dispossession. Rather, I suggest that it is imperative to unpack the cacophonies that have come to be covered over by the curtain of social justice, specifically with regard to the agrarian-centeredness in alternative food work.

\section{Tend, Gather, and Grow}

From The Western Slopes of the Cascade Mountains to the Salish Sea

There were a series of posters wheat-pasted across Seattle in January, 2015 pronouncing "YOU ARE ON INDIGENOUS LAND." It was part of a photographic

portrait essay and public art project created by Longhouse Media artists Tracy Rector and Melissa Ponder. They had worked with several of the city's art venues to highlight the region's variegated Indigenous community, and some of the Native people who call Seattle home. A year later, I found myself in GRuB's farmhouse sitting across from Mariana, a young Yakama woman who was featured in that public art project, wearing a pair of earrings engraved with the same words: You Are On Indigenous Land. 
I cannot speak for other settlers in terms of how "we" interpret what it means to encounter this statement, but I think it is easy for settlers to facilely affirm such a reminder without doing much to contemplate the interruptions it makes - how it might complicate settler politics, be they liberal, progressive, or radical. Particularly in entering this project in the capacity of collaborator as well as a researcher, including a growing friendship with Mariana, I felt obligated to spend un-easy quality time with this unspoken encounter. I certainly considered this to be more than a statement about local cultural ongoingness - but knew it would take more searching to think through the forms of accountability into which this statement, this encounter, enrolls me. Being on the other side of this months-long participant-observation experience, I now consider this unverbalized exchange as one that gets at the heart of my questions about settler food activism. The words "YOU ARE ON INDIGENOUS LAND" do not ask for greater equality, inclusion, or recognition. They expose the settler colonial present, speaking directly to those of us plugged into the structural position of settler.

The way TGGmapped the terrain of our work turned on the premise that we and future students and educators of this curriculum - Indigenous and non-Indigenous people - live on Coast Salish lands. How we articulated the geography of our work was something already defined and well thought out in previous projects developed by TGG members. From the beginning, we discussed the potential adaptability of our toolkit to other places, but we defined the scope our work as spanning "the western slopes of the Cascade Mountains to the Salish Sea." Our lessons and discussions on the relationships between plants and places elucidated that within this expanse, urban centers-Seattle, 
Tacoma, and Olympia — are neither outside of nor aberrant to that which comprises Coast Salish land.

\section{Stories and The Land}

On our third meeting at the GRuB farmhouse, the presence of someone new grabbed my attention and curiosity. Elise had invited Roger Fernandes to speak with us that day about storytelling, nettles, memory, and livability. Settling in to the circular formation of table in the main room, most of us clasping mugs of coffee, we started the day by checking in with in one another, each one of us sharing something about our emotional state, recent matters of personal contemplation, or other feelings or ideas we wanted to share. This became a kind of a ritual throughout the project, nurturing our interpersonal affinity for one another. After our check-in, Elise presented Roger, explaining that our morning would be dedicated to listening to and speaking with him.

Roger introduced himself to those among us who did not already know him. He began by sharing that he is a member of the Lower Elwha S'Kallam people, and that he is a tribal artist and storyteller. Before sharing a number of Puget Salish stories with usabout nettle valor, cedar generosity, and raven wiles—-Roger had much to say about Indigenous storytelling in Salish Sea country. This tradition of storytelling, unlike Western philosophical traditions, balks at the mythology of res cogitans, the notion that the mind could be either discrete or prior to the stomach. Roger reminded us human minds came onto the Earthly scene long after the proliferation of life through a multiplicity of (eating) bodies. He quoted Derrick Jensen, that "even the most progressive western philosophers still generally believe that listening to the land is a metaphor" (cf. 
2000). The epistemology entailed by the tradition of storytelling of which he has become a teacher, takes land to be something ungeneralizable, constituted by nonhuman knowledge-holders and makers. His commitments to the epistemology and way of knowing as a storyteller motivates his participation in collaborative projects like these because whether or not traditions knowing with and from nonhuman others survive is an existential matter. Of course Roger did not extend an invitation to become Indigenous or know any and all Coast Salish stories, but he did find an exigency in inviting people living on Coast Salish lands to contribute to our mutual livability by being accountable to long-established traditions, knowledge systems, and social orders in this place.

This was the first time I heard the story of how nettle made the people strong. The story relays a time when invaders from the northern regions of the Salish Sea routinely canoed south to raid the smaller villages along the Elwha River. "The people were afraid," he repeated. When they would hear the northers southbound canoes, the people scattered and hid. "They were afraid." During this frightful period, nettle began to visit one young man in a series of lucid dreams. Nettle coached him to memorize words that made up a song. In the following days, the young man taught the song to his people, and instead of scattering when the northerners appeared, the people stood together and sang in one voice. Their display of strength repelled their antagonists for good.

As he finished the story, Roger's eyes surveyed our faces. He asked us what teachings we had each drawn from the story that might orient us to the way we live in this place today. Quickly a conversation took hold about how nettle edifies qualities of strength, particularly the strength community engenders. Nettle is a formidable plant. It must stand its ground and protect itself from an overwhelming array of critters that would 
benefit from consuming its especially nutritious leaves. Elise related the story to nettle's nutrient and fiber richness - far surpassing popularized "super foods" like kale in its iron, vitamin $\mathrm{c}$, and calcium content. Nettle especially fortifies human immune systems and supports heart health. Roger and Elise agreed that one vital teaching for contemporary Coast Salish youth is that "nettle can still keep people strong" by addressing the emergence of food-related chronic illnesses in recent years, especially the epidemic of type II diabetes experienced by Indigenous communities here, ravaged by the effects of being largely dispossessed of long-practiced food systems characterized by abundance and a highly variegated diet. Mariana related some of her reflections while recently spending time with nettle in parks around Tacoma. Seeking out, harvesting, and tending nettle near her home reminded her that cities continue to be places of abundance, even as profoundly altered lands, and despite the axiom that urban environments are places choked off from nature. Cities remain very much part of her geography of traditional food harvesting as a practice of Indigenous resurgence.

\section{The Plant People}

In my preliminary conversations with Elise, I came to understand that TGG would be a plant-based curriculum structured around Puget Sound seasonality. We would focus developing lessons around several plants each month, overlapping with when particular plants emerged, flowered, fruited, or offered particular kinds of food and medicine temporally — willow in late winter, camas in spring, salmonberries in early summer, and huckleberries in August. The Tend team developed several activity- and inquiry-based lessons for each "plant person" that were targeted to and/or could be modified for various 
age groups. Each lesson articulated a specific set of learning objectives that satisfied state standards for various grade levels. We especially put effort into ensuring the lessons helped students identify a plant species, know where it grows and can be found (in and/or outside cities), understand its nutritional and/or therapeutic qualities, harvest it responsibly and sustainably, be able to make food or medicine from it, grasp its ecological relationships to other forms of life where it lives (including people), and appreciate its historical co-evolution with people as part of Coast Salish lands and lifeworlds.

Our curriculum sought to integrate knowledge bases, but foregrounded the insights of the Coast Salish knowledge holders among us, particularly regarding harvesting grounds and methods, ways of tending Coast Salish plant landscapes, plantderived foods and pharmacopeias, as well as a philosophical and epistemological basis of approaching human-plant-land relationships. Our group included Native educators, plant lovers, state-accredited sciences teachers, herbalists, food activists, Indigenous rights activists, grant-writers, researchers, and an ethnobotanist. There was a core group of long-time friends and collaborators who had been doing Coast Salish food and medicine revitalization work for over ten years.

The project emerged out of the work of a cohort of Coast Salish traditional foods revitalizers and tribal food sovereignty organizers who began to reorganize themselves after deciding to re-focus their efforts away from the Northwest Indian College (NWIC), where they had implemented tribal food sovereignty and Native plants and foods curricula. Working under the new moniker the "Northwest Native Foods and Plants Collective" (NWNFPC), this coalition of Native food educators, TEK and cultural 
knowledge holders, and tribal food activists began to create a new set of initiatives and partnerships outside of NWIC that focused on revitalizing traditional plants knowledge and organizing to strengthen and promote tribal food sovereignty in the region.

Elise Krohn, who had apprenticed with Skokomish Elder Bruce Miller, put together TGG, gradually realizing it by bringing on many of her longtime collaborators, including Valerie Segrest (Muckleshoot), Elizabeth Campbell (Spokane), Mariana Harvey (Yakama), Aleta Proste (Squaxin Island). Bruce Miller was a tribal leader "whose teaching nourished a Salish renaissance of art and culture in the Northwest and beyond" (Mapes, 2005). Miller was appointed cultural and educational director of the Skokomish Tribe in 1971, earning prominence for his traditional knowledge, "including a repertoire of more than 120 Skokomish tribal stories, some of which take days to tell" (ibid). Miller played a critical role in reviving a number of ceremonies previously banned the U.S. government. Miller took on numerous apprentices to whom he was careful to pass on various areas of expertise. Elise, though non-Native, apprenticed with Miller for years as a student of plants, nutrition, botanical medicine.

TGG constitutes part of the ongoing work of members of NWNFPC, and as a result of long-term deliberations and strategizing about to meaningfully advance tribal food sovereignty, address community identified needs within tribes, and put forth Coast Salish science and knowledge as fundamental to livability. The wars on livability in Coast Salish land are evident in the decimation of salmon populations and other species, the scourge of diabetes, the toxification of the land waterways, the ecological chaos associated with climate change. Their work links these conditions to a critical knowledge about the loss of food sovereignty, and reassertion of it through a range of everyday 
practices as well as political struggles - ranging from re-acquisition of land bases, creating systems of knowledge transmission, elevating community members by nurturing and celebrating their skills and knowledge, harvesting, cooking, medicinemaking, and land-tending.

The pedagogy of TGG centered around the "plant teachers." As we began to meet as a team, I quickly learned that TGG would develop its plant-based curriculum in a way that presented the plants not only as agentive life forms, but specifically as 'teachers.' It is not my objective as a researcher to analyze the cultural logics at work in how Coast Salish people talk about the plant people, the tree people, the salmon people, or nonhuman others as teachers, except that these articulations expressly aren't metaphors. Rogers storytelling-epistemology discussion helped to understanding the ways it is stated that the land has and holds knowledge. Without any formal introduction to Coast Salish epistemology of nonhuman agency, the group simply deemed it important and appropriate to approach the plants as people-like, with personality traits, particular kinds of expertise, and that have histories of social relationships with people involving various forms of mutual responsibility.

In the span of the first year, we drafted lesson plans for our thirty plant teachers, working our way through the seasons. In late winter/early spring, we worked with willow, nettle, alder trees, cottonwood trees. In mid to late spring we engaged camas, dandelion, cattail, horsetail, Oregon grape, and salmonberry sprouts. In summer, we delighted in working with wild rose and rosehips, yarrow, salmonberries, thimbleberries, blackberries, wild strawberries, and especially mountain huckleberries. In Fall we 
deliberated hawthorn, salal, and elderberry; and winter turned our attention to the "tree medicine" of Douglas fir, hemlock, and western red cedar trees.

As the team worked to develop lessons for each plant person, we first discussed each one as a larger group, often covering several in the span of each full-day meeting. After deliberating as a larger group, we would break out into smaller sessions that would each focus on fleshing out a lesson plan for one of the plants. Every meeting entailed some form of interaction with the plants we were discussing, either via specimens harvested by Elise or other team members (often prepared as a food, tea, tincture, or medicinal product), outings around the GRuB farmhouse, or fieldtrips across western Washington. In our initial discussions of each plant person, we covered a similar terrain of topics: where it grows geographically and environmentally, its nutritional and/or therapeutic properties, how Coast Salish people and others have used and tended to it, its distinguishing characteristics and lessons, how long it has lived here, what other kind critters it helps to support or is supported by, how to identify it, how to sustainably harvest it, how to make various foods and/or medicines from it, and its English, Coast Salish, and sometimes Latin names.

Salmonberry, for example, or tca'a'xiwap'ut in one Lushootseed dialect, likes to grow in moist areas in forest understories and along streambeds. Before the berries emerge in summer, its shoots can be harvested by pinching them off at the base of the bush. To eat it, you peel back the outer skin of the shoot. I tasted my first salmonberry shoot standing just outside of the GRuB farmhouse, after Elise brought us to a salmonberry bush to show the group how to identify when they are ready to be plucked, noting how they have turned a deep pink color. The sprout was mildly tart, soft, and 
increasingly bitter near the end of the shoot. In our group meeting, we discussed how Salish Elders describe salmonberry sprouts as an important early spring food that helps to wake up the body after a long winter. Elise, the herbalist among us, explained that the astringency of the sprouts is related to its ability to soothe inflamed tissue. They contain high levels of vitamin $\mathrm{C}$ and other minerals and have been associated with infusing the body with new strength after winter. The berries emerge in late spring, and are intimately associated with Swainson's Thrush—“the salmonberry bird," who arrives in the region just when the golden, red, and purple salmonberries are ripening. The lavishness of salmonberries from year to year are associated too with the first inbound run of sockeye salmon, and are said to be predictive of how abundant the run will be that year.

We discussed elderberry and hawthorn as Autumn approached at the end of berry season. The group associated berries during this time with winter immunity, and we transitioned from the delight of picking and eating fresh blackberries, strawberries, and especially huckleberries, to harvesting and preparing long-lasting syrups, tinctures, and teas from elderberry and hawthorn. For this meeting, Elizabeth brought with her a jar of hawthorn berries she had harvested, along with full stems of elderberries that we later prepared as syrup. We discussed the tradition of preparing elderberry this way to build up immune system strength just as the weather began to turn cold and wet. Elizabeth proclaimed that during September, in the beginning of the school year, she gives her children one to two teaspoons of elderberry syrup a day, and that they have never caught the seasonal flus that come through. Elderberry leaves can be dried and subsequently used to make teas. Elderberry and hawthorn are packed with antioxidants, vitamin C, and flavonoids. Flavenoids protect and strengthen blood vessel walls, and in recent scientific 
literatures are proven to protect from cardiovascular disease. Charlene shared her knowledge about how hawthorn is considered medicine for a "sad" or "heavy" heart, connecting healing properties with regard to blood and heart heath with depression or an aching heart.

There were two times during the year that we collected dandelion; first in May to harvest the flowers, and second in October, to harvest the taproot and leaves of the plant. Charlie and Mariana eagerly looked forward to making dandelion biscuits for lunch. In our morning discussion, we talked about how Americans perceive dandelions as a lawn nuisance and unremarkable weed. The U.S. Federal Government indeed lists dandelion as a weed (Berrigan 2014). Yet Western European emigrants intentionally brought dandelion with them to the Americas as a proliferative plant with beneficial pharmacological properties and nutrient content. Dandelion derives from the French for "teeth of the lion," in reference to its fang-like petals that are long and coarse. Dandelion was introduced to the Pacific Northwest by European settlers and immigrants, and subsequently became important to Coast Salish people an herbal remedy source. The bright yellow head of a dandelion is comprised of hundreds of individual flowers, or florets (often mistaken for petals). The florets are fiber and antioxidant rich, contain high levels of Vitamin A, Vitamin B12, potassium, calcium, and magnesium, and retain an antibacterial property. These nutrients are more concentrated in the roots and leaves of dandelion, along with sesquiterpene lactones. Recent scientific research points the ability of sesquiterpene lactones to reduce inflammation and tumorigenesis in human bodies (Chadwick 2013). 


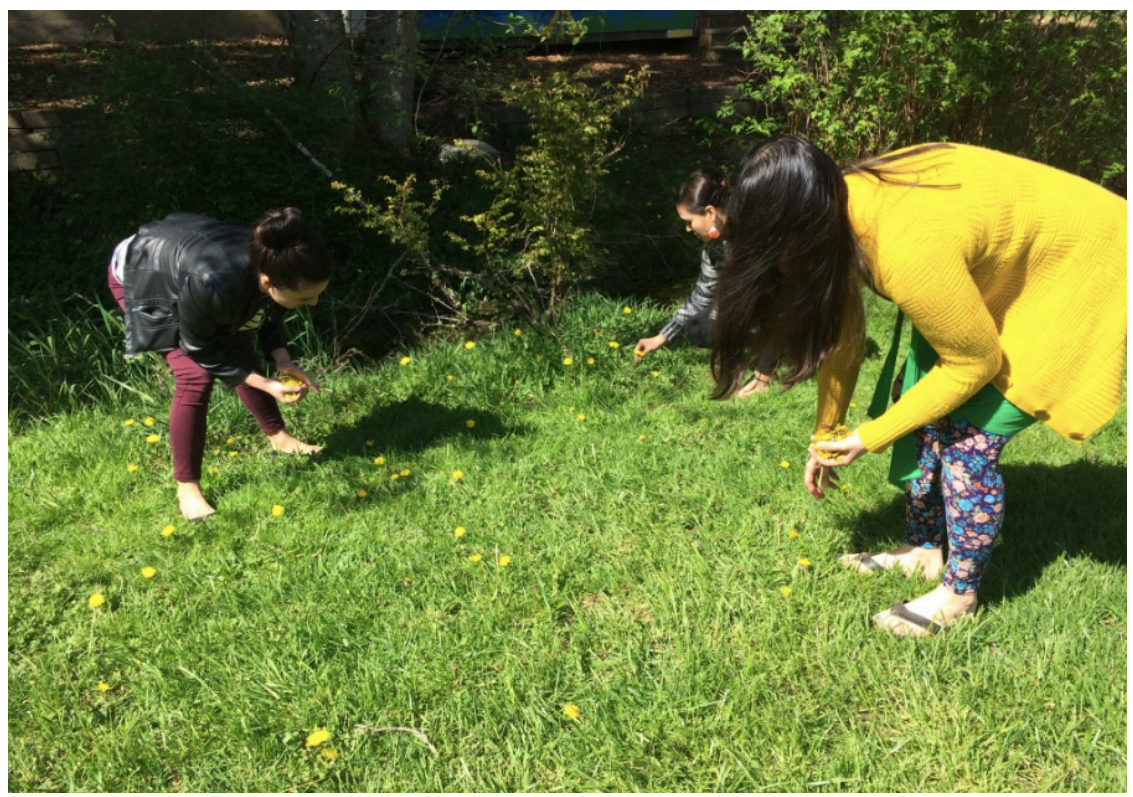

Fig. 3.1. Tend, Gather, and Grow team members gathering dandelion to make dandelion biscuits (April 16, 2016).

After concluding our morning session, I followed Charlie, Mariana, and Aleta to the back of the GRuB farmhouse to harvest dandelion. They were giddy about making this simple harvest and eating the biscuits. Using our hands and clothing as harvesting containers, each of us collected 15 - 30 bright yellow heads and brought them into the kitchen where we often collectively prepared lunch. Charlie taught me how to make the biscuits by pulling the florets from the head and setting them aside in a dish, then simply adding them generously to a biscuit recipe. Our dandelion lesson included recipes for dandelion biscuits, along with dandelion root and leaf tea.

At lunch, we dined on the dishes members of the group brought and prepared in the GRuB kitchen, including the dandelion biscuits. A discussion emerged about dandelion. Mariana and Charlie were especially excited to dig into the biscuits. Expressing her affinity for dandelion, Charlie remarked on how incredible it is that 
despite the purposefulness that brought dandelion to North America as a powerful medicine, it is ubiquitously disliked and overlooked today. Our chat turned to plant migrants and newcomers to the region — at which point several people reiterated how dandelion makes a remarkable counterpoint to another bright yellow botanical character: scotch broom. Upon my first visits to the Northwest during the summers, I had always noticed the vast swaths of yellow bushes beneath the conifers. I did not know scotch broom is notorious as a particularly pushy, aggressive, and violent newcomer—pushing out existing plant and animal life as it took existing ecologies, and not known to offer much nutritionally, medicinally, otherwise. Carpooling to Olympia from Seattle with Joyce, another team member, she would lament its ugliness in the landscape. Yet dandelion embodies how newcomers can make wonderful neighbors-moving into the landscape without causing harm to others, and offering new gifts to the community that that is there. Dandelion became an important "local food" that Coast Salish people incorporated in their pharmacopeias and diets as it migrated into the Puget Sound area, even preceding waves of Anglophone settlers. Elise reminded us how Bruce Miller remarked that it takes several times before meeting someone new before you can determine whether or not you like them — and in assessing a member of the community, the important question to ask has less to do strictly with a native/migrant divide than whether or not they are a good neighbor. As the group continued to make jokes about scotch broom, Elizabeth displayed her tremendous generosity of spirit, noting that scotch broom gets its name because you can use it to sweep. Elizabeth seemed to always model the overarching ethos of our project, and one of Bruce Miller's teachings, that everyone 
has something to give, and we might bring out one another's gifts through acts of good faith, generosity, and modeling collaborative relationality and reciprocity.

\section{Plant People and the City}

In addition to generating lessons around specific plant people, TGG fleshed out a set of broader teachings to be instilled across the curriculum. To elaborate these educational themes, members joined different subgroups that worked out broader concepts we considered to vital to the overall pedagogy of the curriculum. I joined the "cultural ecosystem" subgroup, in which we attempted to find ways to help youth conceptualize the range of environments where plants grow as places co-created by humans and nonhumans, including cities.

In the notes, we subsequently presented the entire team, we defined "cultural ecosystem" as "a concept that highlights the co-constitution of nature and culture, and how non-human agents create places together with humans." Through this concept, we hoped to emphasize and put into relation several insights. First, that human culture has co-produced the plants and other nonhuman life forms we encounter (through networks of food and eating) in "nature." This includes specifically introducing Indigenous methods of cultivation and "tixdxw," a Lushootseed concept "foundational to Coast Salish understandings of care for humans and the more-than-human world" (Lecompte 2014). Second, that the cultural practices that shaped the landscapes around us do not belong solely to the past. Third, that people are part of the land, and we can have a positive impact. Fourth, that other creatures have not only agency but cultures that contribute to the ways ecosystems manifest. Finally, that in talking about ecosystems in 
this way, we include cities, where many precious plant relatives continue to grow alongside new and old relatives - that these are also ecosystems subject to questions about relating well for the sake of the lifeforms we find there. In thinking through ways to convey these ideas to learners, we discussed showing a variety of pictures as illustrations of the kinds of places that we can think of as cultural ecosystems. We liked the idea of sharing stories that help get at these concepts. Elise shared her story about growing up learning to feel badly about being a human - that humans were innately damaging to nature. That began to change when Bruce Miller took her to visit to a camas prairie. She came to see how places are cultural, having history, that thriving through management.

We noted that many of the students of this curriculum would live inside cities, and therefore we hoped to emphasize that these were important cultural ecosystems too. The settler conflation of Indigeneity with wilderness renders cities as places where Indigeneity is especially considered only in vestigial terms. TGG includes Puget Sound's cities as part of Coast Salish lands and territories, and places to nurture right relations with plant relatives. Our lessons on nettle and dandelion were opportunities to give students the chance to look for, identify, and harvest these plants in urban and peri-urban areas. 
Food and "Story-ing" Ourselves to Indigenous Land: Accountability to the

\section{Lands of Landscape}

Settler is not a synonym for migrant. It is not simply by virtue of being newcomers that a group of people become 'settlers'. The colonization of a place does not refer solely to the introduction of new people or other species. As colonizers who come to stay, settlers "enforce their interpretations on everyone and everything in their new domain" (Tuck and Gaztambide-Fernandez 2013). Settler is not an identitarian category. There are not strict boundaries neatly separating settler/Native/migrant—a triad upon which I elaborate in subsequent sections of this dissertation, yet it is an effects-making structural category that cannot be undone through disavowal. How non-Native people might decolonize settler colonialism remains a crucial area of scholarly investigation. Dandelion, perhaps, is one entry point into that discussion.

First, I would like to outline the ways TGG contravenes into the kind of food justice activism typified by GRuB as well as the broader US alternative food movement, even as it finds point of overlap where collaboration can be fostered. By highlighting the contingencies and incommensurability at play in this collaboration, I seek to open up new arenas of contemplation, debate, and re-theorization that might offer new possibilities for solidarity, food system change, and collaborative worldmaking.

For all of GRuB's historical emphasis on sustainable, local, and urban farming and agriculture, it was now hosting a food project that did not once refer to farming or agriculture. This "local food" project presented food cultivation in terms of tending, gathering, growing, and harvesting plants as reciprocal acts with them as agentive food 
and medicine givers. Affinity permeated TGG. Yet affinity itself does not overcome how discourse, practice, politics, and land use enact divergent worldmakings. The tensions I describe are not ones of overt, interpersonal conflict, but rather underlying incommensurability in terms of what futurities are being enacted through the discourse, politics, and praxis of food work. Sometimes this erupts as interpositions - whether they are noticed or not—-such as Valerie qualifying that nettle's importance comes from not simply being a local, organic food, but as itself a relative and reinstating right relations with that relative - as part of a longstanding multispecies community and social order that continues to be wrongly suppressed, displaced, and contained. Or, the presence of Mariana's earrings announcing to all that we are on Indigenous land within a space that has narrated the environment in ways that obscure naturalizes and secures settler futurity.

A recent piece in the popular press highlights one of GRuB's students as a success story. Having become enthusiastic and knowledgeable about farming and gardening through GRuB, she received a full scholarship from Evergreen State College to pursue her passion. In the piece, she states that her "ultimate dream is to run a GRuB farm on [her] own 94-acre property" (Haller 2014). A vision to expand privately owned farmland by non-Native people on lands not acknowledged as Coast Salish is deeply misaligned with Indigenous food sovereignty in fundamental ways. Yet Indigenous sovereignty is at the heart of a project that has now been added to GRuB's list of community-engaged and "youth-cultivating" projects.

As an organization dedicated to social justice through food and eating, GRuB holds up agriculture and gardening as key ways to usher in a more equitable community. Particularly having observed GRuB's reiteration of the agrarian imaginary, and the way 
agrarianism worked to prop up the doctrine of terra nullius, their self-described landbased work rehearses settler "constructions of land, implicitly or explicitly as no longer Indigenous," naturalizing settler futures (Bang et al. 2014).

One of TGG's interventions is that it "stories" the land as Coast Salish, teaching those living on these lands to "story" themselves to the land as Indigenous, whether they are in "currently ceded urban territory or not" (ibid). K. Wayne Yang discusses "storying land" as a way of moving "place back, between, and beyond to Native land, providing a transhistorical analysis that unroots settler maps and settler time" $(2014,114)$. A group of Indigenous and non-Indigenous education theorists in Chicago discuss "story-ing land" as a way to generate "long views of time and experience, and elevating the importance of and reclaiming naming practices we see as critical dimensions in" Indigenous urban landbased pedagogies (Bang et al 2014). TGG narrates urban spaces as part of Coast Salish lands even if markedly transformed, not only as places where Indigenous people continue to live, but where livability entails long-established modes of relating to plants and others. It helps people to relate to Seattle, Tacoma, and Olympia as part of the region's variegated and long-managed forest, prairie, and riparian zone landscapes, where some of the most cherished plant foods and medicines still grow. This engenders "longer views of $[\ldots]$ communities and $[\ldots]$ homelands not enclosed by colonial timeframes" (Bang et al. 2014, 3).

Indigenous erasure from the land, urban land especially, is not only a function of settler colonialism's conflation of the construct of wilderness with Indigeneity, but the role that multicultural politics play in reinforcing racial Indianness. "Historicized victory narratives of conquest and assimilative narratives [...] place the discourse of indigeneity 
within colonial realms of race - not in discourses of territory and sovereignty" (Bang et al 2014, 6). By approaching Indigenous food struggles as something stemming from identity or a form of marginalization that can be added onto the roster a social justice project dedicated to "equality," negates Indigenous struggles for sovereignty and decolonization are inextricably about the land, and how relations to it are constrained by the settler state.

By centering Coast Salish epistemology, TGG fosters the ongoingness of Indigenous relations to land as relative/s—not a set of resources to extract or conserve. Thus, where place-based education leads simply to [...] re-inhabitation, [Indigenous land education] leads towards repatriation [...] of Indigenous land and life as [people] have survived before, during, and beyond colonialism" (Yang 2014, 124).

\section{Becoming Accountable to Unsettling Geographies}

Placed-based and environmental education have always been "critical sites of struggle because they typically reify the epistemic, ontological, and axiological issues that have shaped Indigenous histories" (Bang et al 2014). Yet in unpacking the ways these are sites of quiet struggle, they are also potential sites of transformation and "desettling" from which to secure Indigenous futurities (ibid).

I do not want to underestimate that GRuB's director meaningfully participated in and offered a home to a project that, on its own terms, is full of decolonizing potential. Kim Gaffi and other GRuB activists work incredibly hard to materialize very meaningful justice work in South Puget Sound. This collaboration, however, offers an opportunity to reflect on the tensions and points of incommensurability between the increasingly 
popular social and environmental work happening under the sign of food justice and urban agriculture on one hand, and the resurgent politics and practices flourishing under the sign of Indigenous food sovereignty on the other. The incommensurability is obscured not only because both seem to broadly oppose or resist the social and environmental impacts of globalized, industrial monoculture. It is also obscured, I submit, because "social justice" needs to be unpacked as a cacophonous arena in Jodi A. Byrd's sense of the term. She defines cacophony as "competing struggles for hegemony within and outside institutions of power, no matter how those struggles might challenge the state through loci of race, class, gender, and sexuality, [that serve] to misdirect and cloud attention from the underlying structures of settler colonialism that made the United States possible as oppressor in the first place" (Byrd 2011, xvii). At worst, cacophony "coerces struggles for social justice for queers, racial minorities, and immigrants into complicity with settler colonialism" (ibid).

Yet this is not at all to say that liberation for the U.S. nation-states abjected others stand in opposition to Indigenous sovereignty. Indigenous sovereignty, and its critique specifically of settler colonialism, opens up different processes and modes of accountability with which to restore human-land relationships. 


\section{CHAPTER 4: Monsters of Domestication: Reflections on Wilderness, Decolonizing Materialisms, and the Specter of Genetically Engineered Salmon from Coast Salish}

\section{Territories}

If the question one sets out to ask is, "do Indians need fish for cultural survival?" then it doesn't matter whether the answer is yes or no. Neither answer will do anything to alter the genocidal logic at play for Indigenous people or the salmon; the settler state can just put up a plaque at the dam site that explains how the people and/or fish disappeared.

Lindsey Schneider

Our elders have been warning us about this for generations now - they saw the unsustainability of settler society immediately. Societies based on conquest cannot be sustained, [...]. We're running out of time. We're losing the opportunity to turn this thing around. We don't have time for this massive slow transformation into something that's sustainable and alternative. I think that the impetus to act and to change and to transform, for me, exists whether or not this is the end of the world. If a river is threatened, it's the end of the world for those fish. It's been the end of the world for somebody all along.

Leanne Betasamosake Simpson

Roger welcomed an audience in S'Klallam and English, then began his talk by stating a desire to shift course a little. He wished to preface his planned remarks, he explained, in order to respond to how "others have set the tone for this event."

Roger is a member of the Lower Elwha Band of the S'Klallam People - a tribal artist, teacher, and storyteller. Seemingly speaking extemporaneously, Roger went on to describe that the territory of his people comprises a stretch of land along the Elwha River, upon which two dams were built "illegally." "My people," he continued, "say that when the salmon returned after the [Elwha River] dam was built, "the salmon were crashing their heads against the wall. The river was full of their blood as they tried to get back up 
the river, but they were blocked by this dam." Throughout his talk, Roger prodded his listeners to contemplate the nexuses between geography, memory, and livability.

Two hundred people had gathered in wəłəb?altx ${ }^{w^{8}}$, a longhouse situated on the University of Washington campus, to address the urgent need to create spaces of refuge and replenishment for salmon. Roger emphasized that in Puget Salish stories about the salmon people, salmon, not humans, exist at the center of the world. This was not simply an introduction to cultural ideas Coast Salish people have about salmon. It was not an appeal to liberal promises of recognition, inclusion, accommodation, or equality. Longmemoried storytelling, like hydroelectric dams, demarcate spatialities of life- and/or deathmaking. The word he used to describe the Elwha and Glines Canyon dams was "illegal." In sharing some of these stories, Roger was entreating something not just about the cultural as a domain of difference, nor only about ontological difference—albeit important, but also something about the geopolitical, about governing, about the enrollment of salmon in the erasure of sovereignties and how those sovereignties have organized co-species flourishings over many hundreds of years.

Roger delivered his remarks as an invited speaker to an event organized by the Muckleshoot Food Sovereignty Project in collaboration with the Community Alliance for Global Justice in March, 2017. It was part of an ongoing collaboration between Indigenous and non-Indigenous food actors in South Puget Sound, building on efforts on the part of Northwest tribal leaders and governing bodies to counter the introduction of

\footnotetext{
${ }^{8}$ wəłəb?altxw is Lushootseeed for "Intellectual House." It was created to support tribal students and as a space where tribal elders and community elders can gather to share knowledge with students and the wider community.
} 
AquAdvantage Salmon into U.S. food markets and coastal production facilities across the Western Hemisphere.

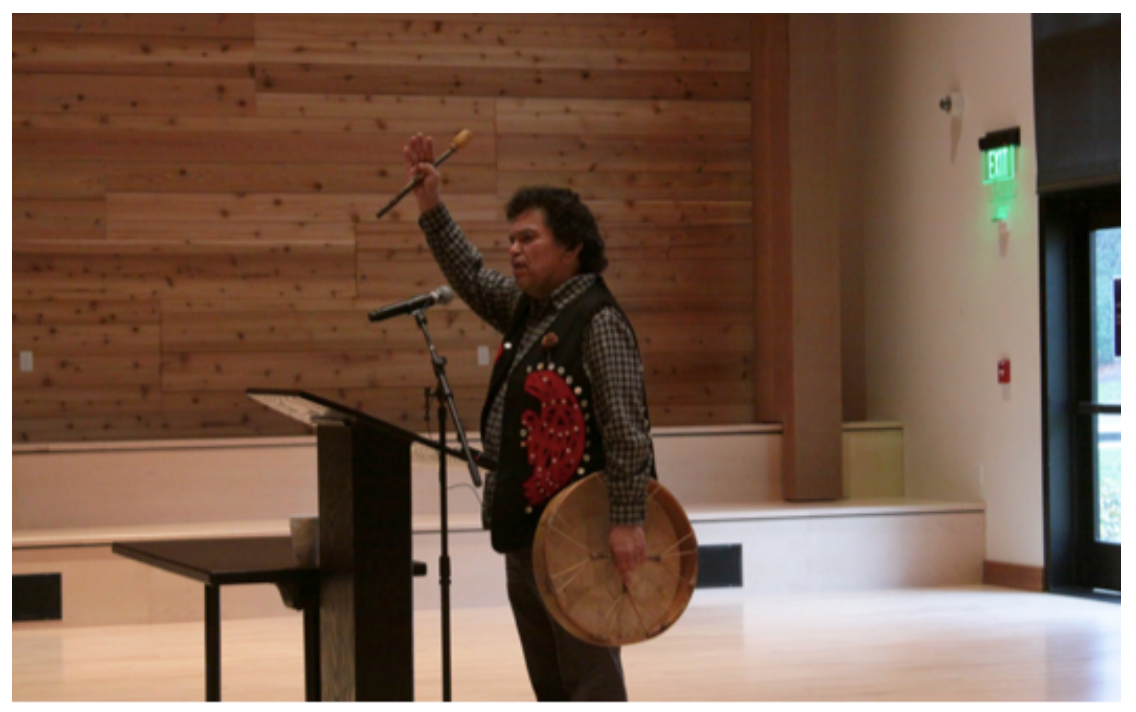

Fig. 4.1 Roger Fernandes speaking at the Wild Salmon Cookout at watab?altxw (March 17, 2017).

AquAdvantage Salmon is the first genetically engineered (GE) animal intended for human consumption - marking a convergence of the biotechnologization of food production with a rapidly expanding global salmon aquaculture market. In addition to engaging a broader public with regard to the potential social, economic, and ecological impacts of global GE salmon infrastructures for the Pacific Northwest, the organizers sought to reframe public debates around this controversial fish by limning its imbrications with Coast Salish sovereignties, territorial claims, legal and critical relationships with the U.S. settler state, and longstanding ways of relating, knowing, and governing across their terraqueous homelands.

While the novelties introduced through the production of a transgenic global food-commodity salmon have expanded GMO food controversies and legal battles, in the U.S. Pacific Northwest they toggle with an enduring history of salmon-centered 
sociopolitical struggles in the context of Indigenous-U.S. settler state relations. I take this point of articulation as an opportunity to re-conceptualize the intersection of Native fishing and water rights struggles, salmon depletion, and Washington State's position within shifting regimes of capitalist accumulation—-from resource extraction for the sake of nation-building to "green" global capitalism. To do this, I draw from and seek to put into conversation literatures conceptualizing the ways co-species becomings, technology, and capitalism meet by focusing on the "politics of refusal" in Coast Salish territories.

In this chapter, I draw from my participant-observation working within a campaign established by the Muckleshoot Food Sovereignty Project and Community Alliance for Global Justice to put forth a settler colonial analysis of the politics around AquAdvantage ${ }^{\circledR}$ Salmon, the first genetically engineered animal for human consumption, and its attendant transoceanic infrastructures, focusing on its imbrications with Coast Salish peoples, sovereignties, and territories.

The expeditious rise of salmon aquaculture in the last 40 years - along with the environmental, ethical, and humanitarian claims and controversies accompanying it—has begun to garner attention from anthropologists interested in these "newcomers to the farm," and in the way aquaculture's attendant practices and materialities complicate narratives of domestication, wilderness, animal welfare, indigeneity, and sustainable futures (see Lien 2015). These questions become even more complicated as salmon aquaculture increasingly meets up with the biotechnologization of food productionwhere genetically modified (and, increasingly, engineered) foods are popularly conceived in terms of a kind of intensification of plant and animal domestication. What does the incorporation of salmon into the category of farm animal —its placement into spaces of 
domestication as a way of increasing cheap, edible biomass for capital and human consumption — mean for the livelihoods of subsistence fisherfolk around the world? What does it entail about salmon in terms of animal welfare ethics? What does aquaculture mean for environmental efforts to remediate the crisis of salmon depletion in the Atlantic and Pacific?

One can already see how wilderness and domestication narratives are shaping public debates around aquaculture and genetically engineered salmon (as a food commodity) either in terms of the noble or ignoble interventions humans make into the workings of nature. Building on the proliferative scholarship that allows us to provincialize the nature-culture binary of which both narratives are a counterpart, anthropologist Marianne Lien instead seeks to set a precedent for slowing down and thinking at the edges of the logics from which wilderness derives. Only this way might we instead grasp something about how differently emplaced practices and technologies have always engendered variegated human-salmon becomings and avoid acting on universalizing conceptualizations that obscure the kind of differences that help life flourish in various places (2015). The kinds of questions she raises find all the more pertinence in debates emerging with the specter of genetically engineered salmon, particularly as the biotech company AquaBounty Technologies Inc. is on the brink of realizing a two-decades long objective of producing and distributing genetically engineered salmon across global commodity networks requiring legal action on the part of multiple nation-states to sell and or produce what would be the first genetically engineered food animal. This particular form of aquaculture - a GE fish-enrolls salmon in what has been theorized in other literatures as biocapitalism, to capture how the 
"substances and promises of biological materials, particularly stem cells and genomes, are increasingly [being] inserted into projects of product-making and profit seeking” (Helmreich 2008).

It is of note that those who have taken up the issue of salmon aquaculture and aquaculture biotech within the environmental social sciences are materialist scholars, but, more specifically, two sorts of scholars of materialism whose conceptualizations of materiality are often expressly divergent and at times opposed. By this I refer to the debates and divides between (Deluezian and post-Deluezian) material semiotics scholars, on one hand, and (Marxian) historical materialists on the other. Toward the end of the chapter, I will outline the congruencies and inconruencies between these theoretical orientations as they have been articulated by scholars working within both. I do so in order to then explore how settler colonialism allows me to think across these divergences, and how putting each of these areas scholarship in conversation further brings into view what a decolonizing anthropology and/or decolonizing politics might mean in relation to human-salmon relationships in a time of aquaculture expansion, biotechnologization of food production, and the "utopian dreams of the blue revolution" (Lien 2015, 169).

I ultimately illustrate how Coast Salish politics and ontologies help to render legible that as a biocapitalist enterprise, AquAdvantage Salmon not only instantiates a new round of environmental enclosures under late capitalism at the level of biological and molecular processes, but it does so via a recursive set of logics, discourses, legal regimes, and socionatures that emerge from settler colonialism's imperative to "eliminate the Native." I go on, drawing especially from Jodi A. Byrd and Eve Tuck, to insert what might be a different emphasis for scholars engaging a material semiotics of human- 
salmon becomings, one the that reframes wilderness not only as a provincializable ontology that variously "rubs up against" other ontologies in places, but one that distinctly originates in the settling of the Americas qua a project of elimination, and which only subsequently has "transited" globally (see Byrd 2011). Such an emphasis underscores what seems to me to be an accentuation within Indigenous critical theory, as well as by my Coast Salish informants, on memory and long-established sovereignties vis-à-vis a kind of radical newness connoted by lines of flight and becoming — which these and other Indigenous scholars articulate as unresolved tensions and real concerns. Following Byrd and Tuck, I concur that in emphasizing what is at once originary, ongoing, and transitive about Indigenous dispossession via US Empire helps to highlight and make legible different accountabilities - to memories, sovereignties, and interspecies relationships that have existed and adapted long before and under US settler occupation. In addition to becoming attuned to the ways different ontological enactments and assemblages come to exist and affect one another as they become proximate, Byrd, Tuck, and others help attune us to what it might mean for us to turn to the diplomatic traditions and sovereignties of those who not only came up against an ontology of wilderness in detrimental ways, but whom wilderness was explicitly designed, at least in part, to disappear.

\section{Salmon and Coast Salish Lands}

'Homelands' might seem a contrary noun to animate salmon-writing, a term that denotes bounded, terrestrial dwelling. Anadromous fish like salmon are travelers and boundary-rebels. They flout national and other proprietary borders, traversing thousands 
of miles of watery space far from and across the land. They cross taxonomic lines along with geographic ones, transforming biophysically throughout their life course to exist as both a freshwater and ocean fish. Marianne Lien aptly describes human-salmon relationships on Norwegian fish farms as 'slippery', noting not only the ways salmon slip through net pens at substantial rates, but how their physical texture influences what they might become in relation to human practices (2015).

Yet we know too that salmon have profoundly steadfast relationships to lands and places. For millions of years, salmon lives in the North Pacific have revolved around their dramatic return-journeys from remote oceanic currents back to the very inland streambeds of their birth. Salmon depletion in the Northwest is not simply a story about overfishing or the tipping points of carrying capacity, but, perhaps, has more to do with how technologies tied to particular land and water use regimes have made the homebound migration trajectories attached to salmon lifecycles near impossible.

It is clear salmon have not fared well in relation to the concrete walls of hydroelectric dams that have populated human-salmon entanglement in the U.S. Pacific Northwest over the last century. Hydrological diversion projects in the early $20^{\text {th }}$ century, along with land-based industries like agriculture and lumber, created possibilities for human resettlement across the Northwest, but worked as barriers against salmon lifecycles that have brought salmon populations to the verge of extinction.

Much of the environmental history scholarship on the salmon depletion crisis in the Pacific Northwest describes the imbrication of the violence against Pacific Northwest salmon and Indigenous dispossession as eventful, less so as structural. When colonialism appears in this scholarship, it is located and lamented in the past tense. While some of 
this scholarship grapples in some way with the tragic outcomes of a colonial history, it is rarer for salmon depletion to be conceptualized in terms of U.S. settler colonialism as an ongoing regime premised on technologies that "enable dispossession to continue in perpetuity" (Byrd 2016).

Roger seemed to hint at the way ongoing colonialism materializes salmon death when he reminded his audience on that overcast day in March that humans have never lived in a world without salmon. It is humans who live in the world of the salmon people, he averred, not they who live in ours.

Indeed, Pacific salmon have migrated through the Salish Sea for several million years. Environmental historian Jim Lichatowich describes them as "among the oldest natives of the Pacific Northwest" (1999).

[Over] millions of years they learned to inhabit and use nearly all the region's freshwater, estuarine and marine habitats [...] From a mountaintop where an eagle carries a salmon carcass to feed its young, out to the distant oceanic waters of the California Current and the Alaska Gyre, the salmon have penetrated the Northwest to an extent unmatched by any other animal. They are like silver threads woven deep into the fabric of the Northwest Ecosystem (1999).

Their presence supports the nutritive and reproductive capacities of dozens of animal species, and supports expanses of plant and microbiotic life. Ecological communities spanning from deep oceans to mountain highlands would become drastically altered if not impossible without migrating salmon. The land flourishes on the oceanic nutrients salmon bring upcountry.

In turn, salmon evolved within the unique geologic, hydrological, and biotic interactions that produced complex streambeds within the waters of the Salish Sea, as 
well as the Columbia River and Snake River watersheds. The emergence of dense highland and lowland forests tens of thousands of years ago created intricate environments to which salmon adapted: the cold rivers that run from glacial headwaters, slowed channels and gravel bars created by fallen tree trunks that make spaces of refuge, the shade of tall firs and cottonwoods that keep waters cool in summer, and the vegetation along riverbanks that provide a ready source of food (Taylor 2001). Five species of salmon evolved here: chinook, coho, sockeye, pink, and chum, with differing migration trajectories that bring them through coastal, intertidal, and riverine waters as "runs" at different times of the year. Much of their lives are spent far in the northern Pacific Ocean, but their life-histories begin and end in freshwater streams and rivers.

The life-cycle of Pacific salmon influence the ways these fish have become entangled in overlapping socio-legal orders and their attendant geographies. Puget Sound salmon, which include all five Pacific Northwest salmon species, begin as fertilized roe in gravel beds in the freshwater of rivers, creeks, or streams. Once they hatch, they begin to move downstream, becoming fry—unattached from their yolk sac and capable of independent feeding. Over a period of 1-3 years the salmon mature into smolt, their bodies transforming to survive in saltwater, and they start to travel in groups toward the brackish water of Puget Sound and onward beyond the continental shelves to deep ocean waters. They circle hundreds of miles out at sea, accumulating a rich array of nutrients feeding on pelagic and oceanic crustaceans, invertebrates, and small fish. Pacific salmon spend up to 8 years in the ocean, and then begin a grueling return to the very gravel bed in the river where they were spawned. They cease to eat as they take this journey, swimming relentlessly for thousands of miles, including through punishing environments 
like rapids, waterfalls, and_occasionally_over hydroelectric dams (Schneider 2016). Their bodies contort in the process; their backs hunch and their upper jaws elongate as they re-adapt to freshwater and prepare to spawn. Finding their freshwater birthplace, female salmon then dig a new gravel nest, spawn with a partner, and spend several days protecting the eggs before they die.

It is commonly relayed in Salish Country that tribal Elders or their parents can recall a time when the salmon runs were so abundant that one could cross the river by walking on the spines of the fish. Early European settlers and explorers remarked on the incredible copiousness of salmon they encountered in the rivers upon reaching the Northwest, which has since been "ranked as one of the natural wonders of the world" (Lichatowich 1999). Environmental scientists and historians suggest that salmon populations reached these levels of abundance approximately 5,000 years ago-levels that were sustained as Indigenous peoples focused their political economies around salmon fishing. Despite recent scholarly interventions illustrating otherwise, the conventional wisdom in settler society is that Indigenous fisheries in the Northwest must have been maintained through innate or de facto "conservation" sensibilities. Yet Western conservation ethics, premised on the invention of wilderness, do not neatly align with many Indigenous cosmologies, knowledge systems, or practices. Echoing Kat Anderson's assertion in Tending the Wild that "California Indians never believed in leaving nature alone," Coast Salish food revitalizers reject the idea that multispecies wellbeing means not interacting with, not transforming or being transformed by, "nature." Indigenous peoples in the Salish Sea region sustained large numbers of people on salmon-centered diets that involved pulling heavily from the rivers (ibid.). Non-native 
fish biologists and ecologists increasingly acknowledge that the long-term sustainability of the Native fisheries in the Pacific Northwest are attributable to the sophistication of what can legitimately be recognized as resource management practices (despite the limits this term denotes), including specialized netting technologies, spatial and seasonal regulation mechanisms, and intricate knowledge systems of the local environment developed over long periods of time.

\section{Nation Building and Salmon Depletion}

Salmon runs began to decline most precipitously in the wake of U.S. continental expansion, though Anglophone colonizers began exploiting the fisheries in the preceding decades. Salmon canneries, logging, agriculture, and dam building are often cited as the most devastating industries to salmon runs during the period of U.S. nation-building in the $19^{\text {th }}$ and $20^{\text {th }}$ centuries.

Logging in Oregon Territory—what is now Washington, Oregon, Idaho, and parts of Montana and Wyoming — began with an increasing need for lumber and to clear land for farming. Yet Puget Sound quickly became the leading exporter of lumber in the region, supporting the boom of mining activity along the west coast (Taylor 2009) and growing numbers of settlers. Loggers gravitated to riparian zones because streams could be used as an easy mode of transportation to bring logs to mills. This activity eroded river banks, resulting in sediment build up in rivers that packed the gravel beds salmon need to spawn. Attempting to regulate timing and stream flows, loggers erected "splash dams" in which water could be retained and then released according to routines that were 
convenient to workers, and to extend seasonal production schedules. These sudden water releases harmed fish and their habitats. Mills further degraded salmon habitat by spilling sawdust into waterways that de-oxygenated the water and stifled vegetation growth (Schneider 2016).

As the cannery business boomed and dwindled, a growing settler population along with west coast mining operations created markets for livestock, wheat, and lumber that ultimately expanded agricultural land and food production, "transforming the biotic assemblage into a more domesticated state" (Taylor 2001, 47). Intense tilling resulted in sediment build up and siltification in waterways by reducing the land's capacity to absorb rainfall, creating massive soil run-off. As with logging, this inundation of soil reduced gravel beds required for salmon to spawn and overwhelmed waterways with excess nitrogen and phosphorus. As railways reached the Pacific Northwest, agricultural markets for food produced in this region had an opportunity to expand. Farmers welcomed the expansion of rail line so that they could tap into these markets and grow their enterprise, linking their potential scaling up with "the advancement of our country" (Taylor 2001, 52). To meet this growth, settlers manufactured water diversion and irrigations systems. Low dams to divert streams created barriers that blocked salmon migration in low summer waters, and farmers occasionally diverted entire streams onto fields, and along with them, adult and juvenile salmon (ibid.). Already by the late $19^{\text {th }}$ century, fish commissioners and settlers were noting declines in salmon runs.

Dams have "played a critical role in the settling of the United States," (Lindloff 2000, 18) particularly in the American West, by supporting agriculture, delivering domestic water supplies, facilitating transportation, allowing for industrial development, 
and providing emissions-free hydropower (Heinz 2002).The capture of technology by a teleological notion of Progress tied to U.S. settler colonialism and Manifest Destiny underwrote the frenzy of dam-building in the early $20^{\text {th }}$ century in the U.S. Pacific Northwest. They quickly became sites of death for Indigenous peoples, salmon, and other ecological communities that have thrived in these lands and waters for thousands of years, or longer.

Hydropower dams in the Northwest have become notorious for their singular role in devastating salmon populations beginning in the mid- $20^{\text {th }}$ century. Built to move "the downstream force of the river's current into electricity," as well as to divert water for irrigation, these enormous structures impact every physical aspect of a river, from its “speed, depth, temperature, volume, and seasonality" (Schneider 2016, 3).

Hydroelectric dam-building during the early $20^{\text {th }}$ century brought ushered in new modes destruction, flooding Native fishing sites, villages, and sacred sites, in addition to transforming the rivers themselves. During this time, tribes initiated a new round of lawsuits against Washington State, while state lawmakers saw treaty obligations as little more than a nuisance and foil to assimilation goals (Richardson 2005). The dams squandered salmon habitat and blocked off the migration trajectories of numerous salmon populations. The depletion and endangerment of Pacific salmonid quickly became and remains one of the most significant environmental, social, and economic crises facing Washington State. 


\section{The Puget Sound "Fishing Wars"}

In the wake of treaty negotiations initiated to incorporate Coast and Puget Salish territories as part of Washington State, the new legal, spatial, and ecological transformations attendant with this transition of territorial claim created drastically new environmental and legal landscapes that betrayed the guarantee that as sovereigns within nation-state borders, they possessed the right to fish in all accustomed places in perpetuity. The decline in salmon populations had already began to rupture Coast Salish relationships with fish. More immediately, Native fishers were quickly criminalized under settler jurisdiction and in relation to settler borders. They found themselves outside of fences erected by settlers around private landholdings marking off harvesting grounds. When they looked for alternative fishing places, settlers would accuse them of taking salmon in ways that were causing the stock declines (Leibhardt 1990).

Soon, Coast Salish people found themselves being policed on off-reservation fishing sites as the Washington Fish and Game department began regulating salmon in response to these declines. As people in settler society began to notice diminishing salmon returns, they paid little attention to the effects of salmon habitat degradation caused by damming, logging, agri-business or other industries and practices had on salmon. State agencies, rather, focused on overfishing as the problem, ushering in a host of new laws to regulate fishing. Without regard for the protections outlined in treaties for Coast Salish people to fish on ceded and unceded land in perpetuity — protections that predicated the very agreement under which Coast Salish people ceded land at all to the U.S. government—lawmakers and enforcers not only subjected Native people to these 
new laws and regulations, but often targeted them, maligning their practices, and scapegoating them for the declining stocks.

By the early $20^{\text {th }}$ century, tribal council meetings across Puget Sound were inundated with complaints in which fishers were arrested for violating the new fishing laws. Puget Sound tribes dedicated their speaking time at meetings for the National Congress of American Indians to how "the whites, particularly the officials of the fish and game departments of Washington State, were violating their treaties and harassing the Indian fishermen" (Deloria Jr. 1977). Early on, tribes organized and invested what resources they had in seeking legal recourse to restore their mobility and sovereign right to fish at their accustomed places. As they maneuvered the legal apparatuses of the settler-state, Salish fishermen also refused to abandon these practices, risking arrest, police violence, confiscation of gear, and imprisonment (Lichatowich 1999).

During this time, industrial development continued apace. However, the mid1960's marked a shift from enthusiastic resource extraction and the natural resource economy to the sobering recognition that these resources were being extracted in ways that could not be sustained, leading to the rise of a conservation ethic and concomitant interventions (Dougherty 2014). As treaty fishing rights became entangled with this new emphasis on natural resource conservation and management, state agencies as well as settler citizens vilified Native fishing practices in new ways, deeming them antithetical to the science of conservation, even though 'the treaty tribes' annual fishing harvest accounted for only a marginal amount compared to the fish reserved for sport and commercial fishing” (ibid). Federal Indian policy during this time, from the 1950's to mid-1960's, was defined by "termination," an assimilative policy that sought to 
incorporate American Indians into U.S. society, entailing the cessation of the government's trust responsibilities to tribal communities. State agencies and settler citizens increasingly viewed American Indians as an ethnic minority whose claims to rights to hunting, fishing, and other practices that did not accede to U.S. spatial boundaries had become excessive and obsolete.

Violence on the riverbanks increased as law enforcement saw Native fishers who refused to stop fishing as unruly and criminal. Puget Sound tribal fishermen, who held this activity to be patently right and legal, returned to the rivers again and again, facing arrest and physical abuse each time. Billy Frank, Jr., the Nisqually fisherman who became the leader of the Pacific Northwest fishing rights movement, recalls his father telling him, "you stick with this river and if the state interferes, let them throw you in jail, but when you get back out, go back to fishing” (Welch 2014).

In the 1960's, these powerful acts of refusal met up with the idioms and tactics of the Civil Rights movement. Tribal members began to stage "fish-in" protests, earning national visibility along with both sympathetic and critical publics. Hank Adams, who had grown up on the Quinault reservation on the coast of Washington, helped to organize a protest (Deloria Jr. 1977) with the National Indian Youth Council (NIYC) (Dougherty 2014) that brought in celebrity civil rights advocate Marlon Brando, who was arrested along with tribal member Robert Satiacum on the Puyallup River.

This marriage between Indian struggles for sovereignty and civil rights activism, however, represented a source of controversy within and between tribal organizations. Even the NIYC, who ultimately decided to adopt civil rights tactics, performed them with caution and qualification. The National Congress of American Indians (NCAI) opposed 
the employment of civil rights activism outright, feeling that it obscured the ways Native struggles emerged from the "unique legal relationship [that tribes held] with the federal government" (Dougherty 2014, 19). They took this to be markedly distinct from the dynamic in which marginalized groups sought to rectify a "racial relationship with the American legal system" by challenging discriminatory policies and institutions (ibid). Tribes, rather, wanted established polices upheld. Indeed, in 1963, the commissioner of Indian affairs, Philleo Nash, used the Civil Rights movement against American Indian communities engaged in sovereignty battles, caricaturing their insistence on political sovereignty as illiberal and regressive. He bemoaned, "Indians want to be thought of as Indian," calling instead for equality via the breakdown of "cultural separatism" (1963). Still, finding cause for alliance with civil rights activists, NIYC diverged with NCAI and made the decision to adopt some civil rights tactics, and rebellions on waterfronts began to take the form of "fish-in" protests that carried resonance with African American sit-ins in the American South.

During this time, regional media began to declare the struggle for Native fishing rights to be a "salmon war" and a "fishing war," as confrontations between state officials and tribal fishermen became more intense, each side prepared for physical altercation. Meanwhile, Puget Sound tribes pursued legal recognition of their fishing rights in court throughout the 1960's and into the 1970's, in which the Point Elliott, Point No Point, and Medicine Creek Treaties became the centerpieces of contested law (ibid). How to interpret the treaties, now a century old, represented a matter of such confusion for the lower level courts that they eventually declared a deferment of all fishing rights cases until the Supreme Court established a precedent (ibid). In 1974, the Supreme Court ruling 
in the United States v. State of Washington indeed established that precedent, ruling in favor of the treaty tribes. It affirmed the tribes' legal status as co-managers of the fishery entitled to half the harvestable catch, and their right to fish at all accustomed and usual fishing grounds. This ruling, subsequently referred to as the "Boldt Decision" after the trial court Judge, George Hugo Boldt, ultimately "upheld the validity, in a modern court, of mid-nineteenth century treaties" and did so "in the midst of threatened natural resources and regional economies, and against tremendous political pressure" (ibid). It has been lauded as one of the most significant Native American Rights successes in American history, while it continues to be a source of substantial controversy in the ongoing politics around salmon restoration in Washington State.

\section{Post-Boldt Salmon Politics and Treaty Tribes}

In the decades since the Boldt Decision, salmon populations have continued to decline despite being a source of intense public debate, scientific funding and research, and government regulation (Schneider 2016). As Puget Sound treaty tribes became legal co-managers of the fishery, they have negotiated shifting relationships with environmental organizations, state agencies, "stakeholder" industries, and various publics, some more conflicting or more collaborative than others. Shortly after the ruling in Washington v. United States, Western Washington's treaty tribes organized an intertribal body — the Northwest Indian Fisheries Commission (NWIFC)—largely through the leadership of Nisqually Elder Billy Frank, Jr., who had been so instrumental in the success of the ruling. Billy Frank Jr. served as the Chairman of the NWIFC until his death in May, 2014. NWIFC organizes research conducted by tribal fisheries biologists, 
creates public reports, serves as a public face for tribal concerns regarding the fishery and treaty rights, and ultimately is committed to recovering thriving salmon populations in the Puget Sound watershed. The focus of NWIFC, often echoed by constituent tribes and tribal members, is on the restoration of salmon habitat, while the Washington State agencies have remained more focused, at least in terms of policy, on regulating fishingincluding where, when, and how much people can fish.

While it is clear that a number of industries affect the watershed in ways that make it exceedingly difficult for salmon to repopulate the rivers, Washington State policy makers constantly seek to balance the "needs" of enterprises important to the state's economy with maintenance of salmon populations, itself a valued "resource." While tribes, environmental NGO's, and environmental state agencies such as Washington's Department of Ecology and the Department of Fish and Wildlife have partnered on local and regional projects to restore rivers and riparian zones, time and time again conflicts emerge in which NWIFC and individual treaty tribes express frustration with the state and federal government's failure to regulate industries enough to sufficiently restore habitat. In 2012, several decades after having helped to achieve one of the most substantial Native American Rights successes with the Boldt ruling, Billy Frank Jr. was urgently cautioning that

We are losing the battle for salmon recovery in western Washington because salmon habitat is being destroyed faster than it can be restored. Despite massive cuts in harvest, careful use of hatcheries and a huge financial investment in restoration during the past four decades, salmon continue to decline along with their habitat. As the salmon disappear, so do our tribal cultures and treaty rights. We are at a crossroads, and we are running out of time (Frank Jr 2004). 
Pointing to the successes of restoration efforts in which salmon populations spiked in response to relieving impediments to migration and spawning, tribes often argue the focus of salmon recovery should be on creating the environmental conditions for salmon to do what have shown, they that can do: repopulate rivers. To do so would mean compromising capitalist logics and infrastructures, such as taking down hydroelectric dams that provide cheap energy to the greater Seattle metro-area, and even large portions of the west coast, impeding the profit-making capacities of giant corporations, or significantly altering industrial agricultural practices.

One particularly nebulous and contentious arena in which Puget Sound tribes have compromised with state and industry in ways that have put them into sharp conflicts with many environmental NGO's is over the use of salmon hatcheries. Salmon hatcheries are "breeding and raising centers that have been built primarily to enhance harvest in commercial, sport, and tribal fisheries, and reduce the impacts of development that destroys or degrades salmon habitat and blocks migratory routes" (FWS 2018). Most Puget Sound tribes have waded between the stance of techno-industrialist actors and their state supporters/enablers who have advanced hatcheries as a "technofix" to the salmon crisis, and environmental groups concerned that hatcheries compromise the vitality and sustainability of wild populations. In his statements on hatcheries during his time as chairman of NWIFC, Billy Frank Jr. expressed, “there's no question that hatcheries have a role to play in salmon recovery, but hatchery fish aren't wild fish, just like hatcheries aren't habitat. [...] Hatchery fish were never meant to replace wild fish, though, and we have to make sure that never happens. Only wild fish can carry us into the next century and beyond" (Frank Jr. 2004, emphasis mine). Northwest tribes have not easily aligned 
with either the conservation/wilderness ethic and its premises, nor technocratic capitalism in their approach to salmon recovery, and tribes' efforts to keep salmon in the waters and restore salmon habitat have come up against what both industrial-capitalist actors and settler environmentalist groups have determined is best for salmon and people in the region.

\section{The Specter of Genetically Engineered Salmon Production}

In the 1990's, AquaBounty Technologies Inc., a Massachusetts-based marine biotech corporation, introduced the first genetically engineered food animal intended for human consumption: AquAdvantage Salmon. They began seeking approval from various national regulatory bodies to produce and sell this "GMO pioneer" early in this decade. AquAdvantage Salmon are the progeny of an Atlantic salmon integrated with a Pacific chinook salmon hormone growth-gene, and a hormone growth promoter gene from the DNA of an ocean pout, an eel-like fish. The marketing of AquAdvantage salmon turns on its intensive and unprecedented growth capacities, reaching nearly three times the size of an average adult Atlantic salmon within a few years.

Currently, AquaBounty Technologies proposes a transnational production infrastructure in which it would produce eggs in land-based facilities on Prince Edward Island, off the east coast of Canada. "Eyed eggs,"-eggs containing a stable embryo, indicated by the appearance of a black spot, would then ship to another land-based facility in the highlands of Panama to feed and mature in enclosed aquaculture pens until they reach market size. There, the salmon will be slaughtered and processed into steaks and filets before being shipped to the U.S. and other countries for retail. 
Yet AquaBounty has previously proposed producing in other places, including the U.S., and clearly as an agenda to expand their production capacities. Steve Mashudo, an attorney working with Earthjustice asserts that "this is the first step in a much larger business plan to expand this product and this biotechnology to a bunch of other places." Using already existing aquaculture infrastructures would offer the cheapest way to do so. AquaBounty initially proposed using existing aquaculture sites in the U.S. to rear their proprietary fish, constituting one of the main impetuses of the response by environmental and food safety groups as well as tribal leaders, all of whom have been staunch critics and political opponents of aquacultural production in Washington State waters.

Salmon aquaculture involves placing salmon in net pens placed in saltwater bodies, requiring a set of domestication practices similar to factory farming, including regular feedings, widespread medicinal/antibiotic applications, and caging as mechanisms for intensive production of biomass from plants and animals. Fish farming has become notorious for breeding diseases that harm fish as well as ecosystems, such as sea lice. Marine ecologists and others have pointed out the inefficiency of fish farming, which requires unsustainable amounts of feed in the form of pellets made from smaller fish. Additionally, salmon escape from net pens in substantial numbers, and while many of those "escapees" die quickly, some find their way back to wild salmon migration paths, potentially interbreeding with or out-competing wild salmon populations. After multiple generations of domesticity, farmed salmon are physically, even genetically (salmo domesticus), divergent from their wild kin, and interbreeding often creates populations of less vital and nutritious fish. Out-competition is particularly concerning with regard to GE fish, because they are engineered to be 3 times the size of an Atlantic salmon, in part 
through shutting down hunger cessation, causing the GE salmon to eat constantly. The overriding concern among tribal and non-tribal fisheries biologists is that, given even the slightest chance of escape into the wild, GE salmon could very conceivably outcompete and overtake their wild relatives, whose present endangerment as a species already represents a social and environmental crisis.

By the turn of the millennium, debates around GE salmon began to imbricate with Washington State salmon recovery politics. Stakeholders saw the need to take preemptive action at the state level against the potential threats to salmon populations by GE salmon infrastructures, as AquaBounty Technologies expressed intent to rear fish in U.S. waters. In 2002, the Washington Legislature passed the Second Substitute House Bill 1499, directing the Washington Department of Fish and Wildlife to work with the aquaculture industry on rules regarding GE salmon in production Washington State. That same year, Washington State passed a permanent ban on the production of transgenic salmon on fish farms in State waters. The Washington Fish and Wildlife Commission adopted these regulations on December 7, 2002. Proponents of the ban included biochemist Bob Barker, Provost Emeritus of Cornell University and past board member of the Nooksack Salmon Enhancement Association, Purdue researchers William Muir (animal Scientist) and Richard Howard (biologist), Shawn Cantrell, the Northwest Regional Director of Friends of the Earth, Joel Hanson, citizen activist, and Dan Swecker of the Washington Fish Growers' Association. Their concerns were primarily rooted in the potential ecological impacts of GMO salmon production, not only as a matter of questions raised by what it would mean for wild salmon populations if interbreeding occurred with escaped GMO salmon, but also because the proposed production plans relied on 
aquaculture infrastructures already proving to be dangerous to already threated fish species, including salmon.

The FDA had still not approved AquaBounty's GE salmon that year. Over the next decade, AquaBounty Technologies continued to retrofit their production proposal in ways that addressed the concerns raised by environmental scientists and organizations around the risks of aquacultural production. Instead of rearing the GE salmon in conventional aquaculture pens, they developed land-based facilities. To further quell concerns about the potential for escaped GE salmon to interbreed with wild salmon, they have decided to produce only female eggs. Yet many environmentalists, fisheries biologists, and communities are not swayed by these measures intended to minimize consequences that further threaten the loss of wild salmon. Even land-based facilities remain vulnerable to various confinement failures, including transportation accidents and storm damage (Clausen and Longo 2012). The kind of regulation AquaBounty Technologies is now promising in order to mitigate the ecological risks posed by the production of GMO salmon involves highly expensive and intricate infrastructures that become less credible 1) knowing the company will be looking to expand once it begins to sell, 2) given the state of U.S. regulatory bodies such as the EPA and FDA under the Trump administration, which continues to move forward aggressively with its explicit intent to bring about the "deconstruction of the administrative state."

In media and information campaigns seeking to shape public opinion, AquaBounty Technologies has aptly deployed a 'food security' discourse that is by now familiar terrain to scholars critically examining the global food regime and its historical precedents. The global movement for 'food sovereignty' itself constitutes a 
counter-discourse to 'food security' - the way technocrats, philanthropo-capitalists, big business and their state affiliates in the Global North frame the problem of global hunger not as a political crisis of distribution, but a technical crisis of scarcity, for which policies and solutions will be shaped by transnational financial institutions, businesses, and international governing bodies not accountable in any democratic way to a global populace.

According to the company's spokespeople, AquAdvantage Salmon offers an efficient way to grow healthy animal biomass on an increasingly populated, hungry, and resource-scarce planet. Ron Stotish, CEO and President of AquaBounty Technologies, makes his case to concerned consumers and regulatory agencies:

We're soon to be 9 billion people on the face of the Earth. We would need to grow over the next 20-30 years our ability to produce food by perhaps as much as $50 \%$. We'll have to do that at a time when terrestrial and oceanic resources are limiting. There's no arable land to expand and explore for production. So how are we going to meet the food needs of the future? When you add to that the developing emerging middle classes who are demanding higher quality diets, how you meet those needs? And the only answer that I'm aware of, is to produce our food more effectively, more efficiently, and more sustainably. And in order to be able to do that, we have to use the same technologies that we have available to us today, and meet those global food security needs. Otherwise, someone is going to have to either eat less or food is going to have to become a lot more expensive, and I don't think any of those sorts of choices are very palatable to American consumers, or more importantly, to consumers in other countries around the world (Stotish 2017).

Typical of what historian Nick Cullather calls the discourse of "the hungry world," Stotish's statements here deploy particular constructions of hunger in relation to development and nature. By threatening that in the future "someone is going to have to 
eat less food" due to population-resource imbalances ignores that billions of people currently experience chronic hunger not because of resource-scarcity, but because of poverty and maldistribution.

In his research on the geopolitics of the Green Revolution, Cullather illustrates that the push by U.S. philanthropo-capitalist foundations and politicians to prop up industrial agriculture in places like Mexico, the Philippines, and southeast Asia was animated by post-Cold War anxieties in which the U.S. looked to secure economic and cultural dominance over the "Third World" over-against Communist expansion. These actors manipulated ideas about hunger to set up an imperative for not-yet capitalist nor communist countries to become integrated into a capitalist economy, specifically by adopting agricultural production technologies and infrastructures that made them dependent upon U.S. suppliers. In hindsight, we know that the result of creating these agro-industrial infrastructures has been the "narrowing of [domestic agriculture's] genetic base, supplanting Indigenous, sustainable practices; displacing small and communal farming with commercial agribusiness; and pushing millions of peasants into urban slums or across the border" (Cullather 2013,68). Despite turning on its capacity qua technology to end global hunger, industrial agriculture never created a less hungry planet. It has only produced a new set of barriers to accessing food and nutrients.

\section{GE Salmon and Biocapitalism}

The introduction of GMO food animals extends controversies around GMO crops and raises a new set of concerns around bioethics, corporate control of genes, international regulation, genetic inheritance, species boundaries, and the definition of life 
itself (Pierce 2015). As social scientists begin to weigh in on the implications of AquAdvantage Salmon, some have begun to note that this biotech food animal instantiates the shift to a bioeconomy, which offers a "fresh round of accumulation" through biocapitalist production (Pierce 2015). Stefan Helmreich defines biocapital as "the rise of a novel kind of capital [...] in the age of biotechnology, when the substances and promises of biological materials, particularly stem cells and genomes, are increasingly inserted into projects of product-making and profit seeking” (2008). Pulling from Helmriech's work on biocapital as well Vandana Shiva's work on bioprospecting, education scholar Clayton Pierce argues that the increasing genetic modification of the food system further entrenches nature in market logics and valuations (2014). Ashley Dawson argues that biocapitalism is not only an extension of neoliberal capitalism and the kinds of subjectivities it requires, but, while enabled by neoliberal governance, introduces something novel. Biocapitalism not only forges new spaces of enclosure, privatizing the commons at the level of genes, but in doing so shifts the production of money via the commodity (as Marx identified) to the production of money via the commodification of bios (2014).

Dawson has recently urged scholars to attend to biotech and SynBio life forms and their imbrications with biocapitalism in terms of how they will interact with structures of and resistances to inequality, imperialism, and projects for human liberation. To date, most social scientific and Humanistic engagements with biotech and SynBio have focused on "onto-ethical" questions about how humans will relate to beings created, in part, through human technology. 
Some scholars working at the intersection of the social sciences and science and technology have suggested that the production of synthetic life forms marks taxonomic shifts that fit together with the emancipatory work of, for example, queer and feminist theory. Sophia Roosth argues that SynBio is kin to queer theory in that it denaturalizes heteronormative kinship models. Both advance theories of kinship that complicate phylogeny, or lines of descent, as how familial relations are made and how life is reproduced. Feminist anthropologists and queer theorists have worked to provincialize biological notions of kinship rooted in heteronormative parentage and siblingship (2017). They highlighted that parental, sibling, and other familial units are commonly formed through material and emotional ties that either do not include, or that complicate, straight biological reproduction. SynBio, like queer theory, she argues, troubles phylogenetic kinship models. Not only does it circumvent genetic descent to create new life forms, but ithas done so by building on "horizontal gene transfers" that happen in nature, processes through which genes move between otherwise unrelated organisms and are subsequently passed down, which have been observed in bacteria, fungi, insects, and plants (Roosth 2017). Roosth portrays this dovetailing between queer theory and synthetic bio optimistically, because they reveal that there never was a “'natural' family that wasn't already sanctioned by social, legal, and cultural norms and decisions" (2017). Acknowledging that nature was always already queer, makes "it easier for synthetic biologists to genetically modify much of the living world, from hypermuscular mice to allergen-free peanuts to 'humanized' pig organs." "The future" she optimistically surmises, "promises to be very queer, indeed" (2017). 
Cultural studies scholar, Ashley Dawson, does not share this unqualified optimism for biotech and SynBio, but rather observes a dearth of critical attention in this arena. Dawson points to how work on interspecies relations have foregrounded questions about how people might ethically respond to—-find solidarity and kinship with— synthetically hybridized biobeings, finding this line of inquiry to be important, but ultimately inadequate in terms of confronting the implications of biotechnological life under the global power nexuses that control its production. He argues, "in addition to cultivating a critical ethical sensitivity to the transgenic other $[\ldots]$ we also need to return to Marx's foundational question: cui bono, who benefits, when species meet” (2015).

While it may be true that contemporary genomics is kindling new forms of lively co-production, which in turn demand new forms of recognition and empathy, I think we need to see such changes in relation to the history of capital's appropriation of bios. For the vast majority of plant and animal species living today, entanglement with human culture comes either through reduction to the status of abject commodity or through obliteration as a result of capital accumulation (2014).

As an extension of the global industrial food regime, the biotech food infrastructure "disciplines and regulates the creative impulse of material life and living labor, placing it in the service of capital accumulation. It plugs the bodies of animals into machines as a way to dominate them" (Parr 2013 qtd. in Dawson 2014). It is critical that the scholarship exploring queer relationality and interspecies intimacies with regard to biotechnological beings does more to attend to the relationships between technoscience, capitalism, and imperialism, including the role of nation-states in setting the conditions of wealth 
accumulation, so that communities can articulate and fight for more ethical ways of regulating and deploying them.

\section{Indigenous Resistance to GE Salmon in Salish Sea Country}

In 2015, the FDA approved AquaBounty Technologies' latest proposal, greenlighting AquAdvantage Salmon for sale in U.S food markets. It relied on 1940's animal food medicine laws to do, categorizing AquAdvantage Salmon as an "animal drug" (Clifford 2014).

As this decision was pending, Indigenous peoples along the west coast with longstanding relationships to Pacific salmon began to organize around their opposition to the introduction of genetically engineered salmon, leveraging their capacity to oppose it on a federal level. Valerie Segrest of the Muckleshoot Tribe describes the response by tribal communities in the Northwest and more broadly in Indian Country to this development,

As soon as it was brought to my tribal council it was unanimously voted against. So we passed a resolution in 2012 opposing the production of genetically engineered salmon. And that opened the doorway to take it to the Affiliated Tribes of the Northwest Indians where it was also unanimously passed. And within six months it was passed at the National Congress of American Indians. So it's safe to say all of Indian Country had no argument, and completely stood in solidarity against the production of this fish.

The Affiliated Tribes of the Northwest Indians (ATNI) resolution (\#14 - 08) to oppose the introduction of genetically engineered salmon passed within two years of the Muckleshoot Tribe's 2012 resolution, in February, 2014. ATNI are comprised of American Indians/Alaska Natives and tribes in the states of Washington, Idaho, Oregon, 
Montana, Nevada, Northern California, and Alaska. The resolution stated that ATNI "strongly opposes the United States Food and Drug Administration approving the introduction of genetically engineered salmon into the United States for consumption, research or production;" and that it is resolved that "that the United States Food and Drug Administration have meaningful government-to-government consultations pursuant to Executive Order 13175 in regards to this issue" (ATNI 2014). The National Congress of American Indians' resolution stated that this body “oppose[s] the introduction and sale of genetically engineered salmon in the United States," and it and requests tribal consultation on the matter before any action by the FDA" (NCAI 2014). To date, neither the FDA nor AquaBounty has made efforts to confer with Western Washington treaty tribes, despite these clear and powerful legal messages from Indian Country and Western Washington tribes.

In the year following the FDA approval of AquAdvantage Salmon, the Quinault Tribe officially joined a lawsuit seeking a decision reversal. The lawsuit, filed by The Center for Food Safety and Earth Justice, is currently holding up AquaBounty's ability to get their patented fish onto market. Members of Muckleshoot and other Puget Sound treaty tribes, including members of tribal governments, scientists, and fishers, have continued to speak out and to organize socially and politically. In 2015, the Muckleshoot Food Sovereignty Project, founded by Valerie Segrest, began to collaborate with the Community Alliance for Global Justice (CAGJ) on a campaign to stop genetically engineered salmon. CAGJ was founded in the wake of the 1999 shutdown of the World Trade Organization meeting in Seattle, by the activists who organized the protest. Its focus is on building activist solidarities with movements in the Global South resisting 
corporate globalization on an array of fronts. One of their main commitments under this broader mission is to the transnational movement for food sovereignty, a term coined by La Via Campesina, a coalition of Indigenous and peasant farmers across the Global South, to denote "the right of peoples to healthy and culturally appropriate food produced through ecologically sound and sustainable methods, and their right to define their own food and agriculture systems" (Nyelini Declaration 2014). CAGJ also partners with local communities and organizations on campaigns for food justice.

Heather Day, the Executive Director and co-founder of CAGJ, became attuned to marine food sovereignty in part through her husband's work as a fisher for a local seafood company. In 2015, she decided to highlight fisher folk at the organization's annual dinner, held under the banner of "Strengthening Local Economies Everywhere" (SLEE). Fishing communities are often overlooked in food justice and food sovereignty work, which are largely focused on national and international agricultural policies and networks. The dinner initiated a formal connection between Valerie Segrest and the Muckleshoot Food Sovereignty Project and the Community Alliance for Global Justice, as Valerie was invited to speak on the importance of salmon habitat restoration and treaty rights for her community. During her talk, Valerie spoke on the topic of GMO salmon. Incredibly moved by her speech, Heather approached Valerie to organize a solidarity campaign around AquaBounty Technologies' GMO salmon. At this time, the company's submission to the FDA was still pending approval.

Heather quickly organized a campaign to "Stop GE Salmon." One of the major efforts that year involved obtaining statements from major grocery retailers to refuse to source salmon from AquaBounty Technologies, or any biotech corporation distributing 
genetically engineered salmon. The campaign was successful, securing agreements from retailers across the country to refuse to sell GMO salmon. The major target of the campaign was Costco, one of the most massive food retailers in the U.S. The major achievement of securing a statement from them, however, was tempered by the FDA's approval of AquAdvantage Salmon for consumption in the U.S. on the very same day Costco issued a statement that it would not plan to sell GE salmon. The approval was a huge upset for Valerie and others in the Muckleshoot Tribe. Yet they continued to mobilize in response. Under Valerie's coordination, the Muckleshoot Food Sovereignty Project began to collaborate with CAGJ to renew the campaign to stop GE salmon. My research partnership with Valerie, Heather and CAGJ began shortly after AquAdvantage Salmon was approved, in early 2016. A colleague suggested that I reach out to Heather to get involved and learn more about her collaboration with Valerie and the Muckleshoot Tribe around GE salmon. I had been in the field in the Puget Sound region for a year by that point, mostly working on the revitalization of Coast Salish cultivated plant landscapes and pedagogies, and their intersections with the "local food" movement in settler society. The group I worked with on Coast Salish plant pedagogies was very closely tied to Valerie, most of whom have been working on Native Northwest plants and foods revitalization and tribal food sovereignty for over a decade. I attended a CAGJ Food Justice meeting in Seattle, where I introduced myself to Heather, and learned more about the campaign to stop GE salmon. We formed a partnership in which I would document these tribal and non-tribal relationships and interactions, and contribute knowledge to CAGJ from my own background on Indigenous food sovereignty. 
In the Spring of 2016, Muckleshoot Indian Tribe awarded CAGJ a grant in support of this work, and CAGJ and the Muckleshoot tribe became community partners in this food sovereignty campaign. Heather and Valerie quickly got to work imagining the near term goals and vision of the campaign. In the longer run, they knew that one tactic would be to continue to work at the level of influencing retailers to avoid sourcing GE salmon, leveraging public support. Because there is already a ban in Washington State waters, the next legal step at the state level would be to influence state representatives to support a Bill establishing labeling laws.

Heather and Valerie wanted to do more to engage the community and help to frame public discourse around the issue, and to specifically raise awareness in settler society about why there is opposition from Indigenous communities, particularly in the Northwest, and how it connects to a much bigger history and politics around humansalmon relationships. To this end, Valerie and Heather developed two major projects. The first was the organization of a community event, inspired by and supported by the Northwest Atlantic Marine Alliance's (NAMA) community work, to raise awareness around the introduction of GE salmon and its social and economic implications for the Pacific Northwest, including for Coast Salish people. The second major project would to produce one or two films - a short film and documentary — aimed at educating tribal and non-tribal audiences about what is stake for salmon and tribes in the Northwest with the pending introduction of genetically engineered salmon onto global markets, including the U.S. The film would aim to center the voices of Coast Salish people. Under Valerie's suggestion, CAGJ recruited Katie Jennings, a documentary filmmaker who has worked with Coast Salish people on award winning documentary films, including "Teachings of 
the Tree People," which shared the work of Skokomish tribal leader Bruce Miller on revitalizing Coast Salish traditional ecological knowledge.

It was Valerie's idea to organize a community event and to produce a film. Originally, the event was going to be modeled after the "seafood throwdown" events sponsored by NAMA, in which the public is invited to watch chefs compete, and the occasion is used to engage people around a particular topic related to sustainable fishing. However, because CAGJ and Valerie wanted to showcase traditional Muckleshoot fishermen and chefs, the competition aspect seemed awkward, and the event was reframed as a "wild salmon cookout." During one meeting, as CAGJ activists deliberated what to title and how to publicize the event, a question arose around whether the purpose was to "oppose" or "stop" GE salmon. I turned to Heather to catch her reaction, and she affirmed, "for us, the point here is simply to 'stop' GE salmon, by whatever means necessary. Whether that means overturning the decision, creating labeling laws, or curbing retail, the ultimate goal is to do everything possible to stop genetically engineered salmon."

Ultimately, the event was titled "Wild Salmon Cookout: Support NW Tribes Stop GE Fish!" and it was held at wəłəb?altxw, or in English, the Intellectual House, situated on the University of Washington campus in Seattle. Wəłəb?altxw is a longhouse facility that was established to support the ability of Native students to "remain involved in their home tribes and communities" and to serve as a space where tribal elders can meet with community members to share knowledge (Wəłəb?altxw 2016). It featured four guest speakers: Roger Fernandes from the Lower Elwha S'Klallam Tribe, Valerie Segrest from the Muckleshoot Tribe and founder of the Muckleshoot Food Sovereignty Project, Peter 
Knutson of Loki Fish Company, Steve Mashudo from Earth Justice, one of the attorneys representing lawsuit against the FDA over the approval of AquAdvantage Salmon and a closing by Simone Adler, the organizing director for CAGJ. Justice Bill from the Muckleshoot Tribe opened the event with an introduction and land recognition, and a dozen Muckleshoot members performed a traditional song. The event turned out a much larger audience than anticipated, approximately 200 people, and received regional coverage by a number of radio, television, and print outlets.

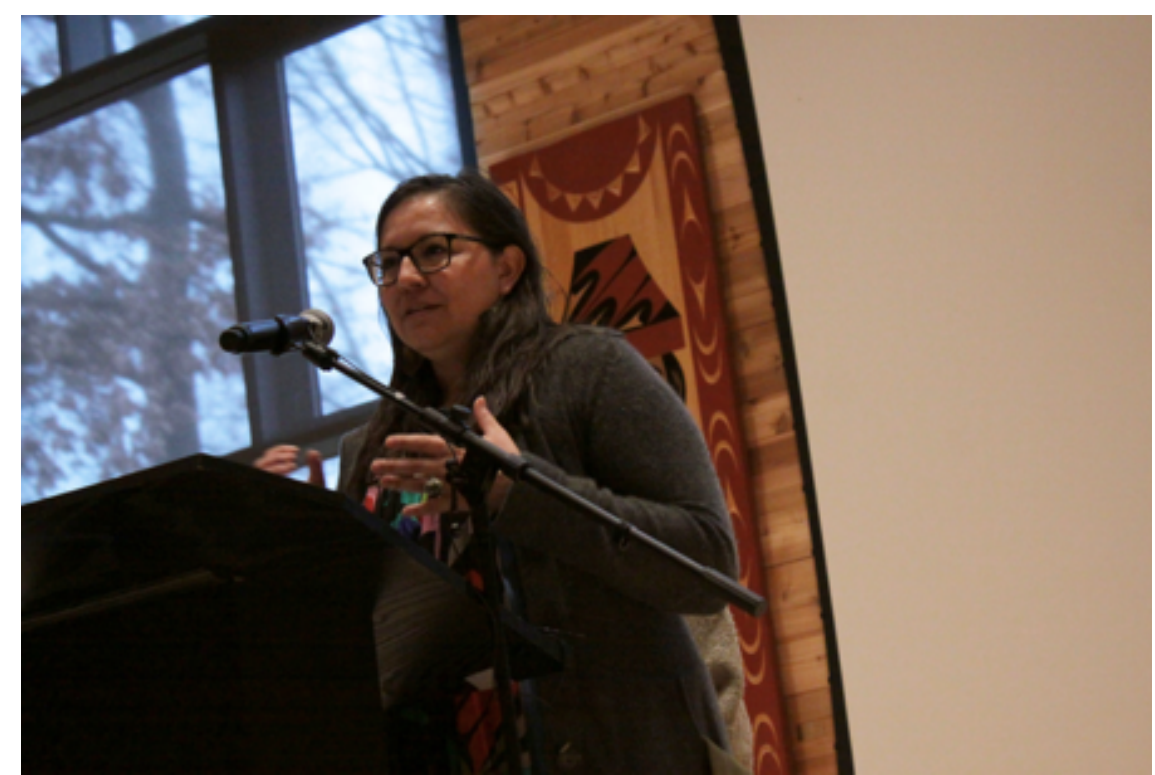

Fig. 4.2 Valerie Speaking at the Wild Salmon Cookout at watab?altxw (March 17, 2017).

During my time observing, interacting with, and conducting textual research on this collaborative activist work, at least four themes seemed to coagulate in the multifaceted way Northwest tribal members and inter-tribal bodies articulate and mobilize their opposition to the introduction of GMO salmon.

First is that it represents a response to the crisis of salmon depletion that takes away from the focus on and investments in restoring salmon habit. In an interview days after 
the FDA approved AquaBounty's proprietary salmon, Louie Ungaro, a Muckleshoot fisherman and tribal council member, objected that this decision "gives big business a way of stepping away from taking care of the habitat which can sustain a wild chinook." Mike Crewson of the Tulalip Tribe's Natural Resource Department expounds on this sentiment. "Cheaper, quickly-maturing, genetically-engineered salmon grown in hatcheries are just another gimmick that takes the focus off of the need to protect and restore salmon habitat and rebuild self-sustaining wild salmon populations. Essentially, this undermines the tribes' and other's salmon recovery focus on rebuilding natural salmon runs by restoring habitat and protecting the environment needed to support healthy natural and hatchery production." Fawn Sharp, President of the Quinault Nation, reiterates this line of reasoning. She explains, "people need to realize that when wild salmon are managed properly, which it is, impetus is placed on habitat protection and restoration. It helps prioritize, and fund, clean water, healthy streams and rivers as well as forests, wetlands and other uplands." She continues, "it helps us emphasize the clean up and prevention of pollution. It also encourages better treatment of our ocean and even our air, as well as helps safeguard our tribal sacred sites and resources” (Sharp, 2015).

Speaking to the audience and the Wild Salmon Cookout, Roger Fernades recounted the construction, and later dismantling, of the Elwha River dams in a beautiful and powerful illustration of what is possible when humans work across difference to create refugia for the salmon people.

My people, the S'Klallam People, live along a river, the Elwha People live along the Elwha River. About a hundred or so years ago, two dams were built along that river, illegally. They were built with no fish ladders, because whoever built those dams said that we don't need the 
salmon, it doesn't matter-we'll farm them. They'll build little aquaculture centers and we'll raise salmon, in pens, which is an abomination if you ask me, but, they said that's what we'll do. And so they didn't put in any fish ladders and the fish were wiped out.

Our people tell stories of after those dams were built My people tell stories of when the salmon returned after [the Elwha River and Glines Canyon] dams were built, the salmon were crashing their heads against the wall trying to get through. The river was full of their blood as they tried to get back up the river, but they were blocked by this dam. [...] A hundred years later, the people have always resisted those dams and said we must bring those dams down, they must come down. And people were telling them, "you can't do that. You can't take down dams on a river. It's never been done before, anywhere in the world-dams of this size." And so if you follow the news, I'm sure you have, you know that a few years ago, the dams were brought down along the Elwha River. And the fishery people said the salmon might return in maybe 4 or 5 years if they return at all. But within six months the salmon were coming back up the rivers. And so, they were waiting for this time to happen. This might sound like I'm bragging about my people, and I am, but, the things people say are impossible are not impossible.

Indeed, the removal of the Elwha River dam in 2012 was historic. The Lower Elwha Klallam Tribe began advocating for its removal since its very inception, and played a central role in organizing a coalition of support to bring removal to fruition a century later, in spite of the power wielded by financial interests of various industries. It was one of the first major hydroelectric dams to be dismantled for the sake of salmon and fish ecologies, establishing an extremely successful and hopeful precedent. Later in the morning, Valerie reiterated the teaching in Roger's story: that what works is restoring salmon habitat, that it is possible to do so, and that it is a matter of political will (currently lacking in settler society). 
Second, AquAdvantage salmon raises questions around corporate ownership of lifeforms and genes as property, including the potential risk of a transnational corporation owning the salmon that swim through Puget Sound and Pacific Northwest waters, should there ever be accidental releases. While the most popularized anti-GMO campaigns in the U.S. have foregrounded the unknown health risks that genetically engineered food may represent, in fact much of the grassroots resistance around the globe to GMO foods and the biotech companies pushing them is responding to the social, environmental, and political implications of (furthering) corporate ownership over seeds, genes, and the infrastructure of the global food system itself. As big philanthropo-capitalists and biotech corporations push to expand GMO production around the globe, particularly in the Global South, small farmers and Indigenous peoples — especially in Latin America and Africa — understand that this represents an expansion of outside control over land ownership and food production by corporations sanctioned and regulated by governments in the Global North, upon whom farmers become economically dependent to supply production materials, if they are not pushed off their farmlands (Holt-Giménez 2011).

The patenting of life in the form of seeds functions as one mechanism through which companies, often from countries in the Global North, "grab" land and the means of production from food producers in the Global South (Holt-Giménez 2011). Like most crop seeds, GMO seeds travel unpredictably via the movement of wind, animals, and water. Wherever the seed lands and reproduces in soil, the yield becomes the property of the corporation that owns the gene sequence. It is not uncommon for GMO seed from various crops, such as corn, to land in and take over the fields that have been used by subsistence, small, and organic farmers for generations. These biotech companies then 
sue farmers if they try to sell the crop growing in their own fields, an ultimately destroy their livelihoods, divesting people of land many cannot afford to regain.

The potential for a semblance of these kinds of dynamics to emerge with the introduction of GMO salmon has not escaped Coast Salish activists and fishers responding to AquaBounty's push to produce and sell a GMO salmon. Valerie Segrest sees this as not only a threat but an attack on her people. She describes the prospect of "corporate ownership of such a cultural keystone" as "a direct attack on our identity and the legacy our ancestors have left us." The idea that Coast Salish people would ever have to purchase their salmon from a company strikes her an act of dispossession.

Yet Valerie's insights go further than highlighting how the dynamics between biotech corporations and local communities and food producers stand to impact Coast Salish people. She highlights why state-sanctioned claims by a transnational corporation to own as property the genome of this fish is grounded in the farce of Indigenous erasure. The "invention" of AquAdvantage Salmon is premised on the notion that AquaBounty Technologies has acted upon human-less nature, or is interacting with non-human life where others have ostensibly not already altered this animal through technology, intention, and human use. AquaBounty Technologies and the FDA, she explained to me along with other CAGJ activists, are ignoring that her "people developed this salmon [Pacific chinook] over millennia, and its nutritional qualities are being advertised to sell an entirely different species." Valerie, along with many other Coast Salish people, understands that the vitality of the salmon that come through the Puget Sound watershed have been influenced by Coast Salish practices over thousands of years. Valerie and other Muckleshoot and Coast Salish people articulate that salmon have co-evolved over 
millennia with their people through specific practices, knowledge systems, legal orders, and ceremonies. AquAdvantage Salmon is premised on the "pioneer logic" that invents wilderness to legitimate certain forms of labor as a process of ownership over non-human life, landscapes, and processes, positioning. It performs settler "understandings of Native peoples, nature, and subjectivity that position Native peoples as having no [...] ability or desire to transform nature into value," rendering the natural world a site of wilderness that Euro-Americans might turn into something of human use (Reardon and Tall Bear 2017, S283).

Third, the FDA's refusal to confer with Coast Salish tribes who organized to assert their treaty rights in relation to AquaBounty's proposal to sell GE salmon in U.S. markets constitutes an attack on tribal sovereignty and a breach of treaty obligations on the part of the U.S. government. The tribes here ceded claim over enormous swaths of land in exchange for, most centrally, the right to fish perpetuity. Particularly given this social and legal history that makes it exceedingly clear that salmon and the Puget Sound salmon fishery are one of, if not the most, significant treaty issues to Coast Salish people, this neglect is felt as nothing short of egregious, politically and ethically, to the Coast Salish leaders who acted on this issue. Valerie expressed that "it was quite disturbing to hear that the FDA decided to move forward" on approving AquAdvantage Salmon despite the resolutions tribal and inter-tribal bodies made at regional and national levels, "especially when they have a fiduciary obligation to speak with tribes, especially on issues that matter to them most, like our sacred food." Fawn Sharp, Chairwoman of the Quinault Nation, has been vocal about this failing too, stating, "although there are 
obvious risks to our salmon, the Food and Drug Administration surged forward with its approval. The agency didn't consider treaty rights."

Finally, time and time again, what I hear Coast Salish people enunciating, not only through my participant-observation, but also in a vast array of historical documents, tribal reports, ethnographies, and documentaries by and about Coast Salish people and their relationship to salmon, has to do with honoring deep time relationships with salmon (and other species and landscapes), and the significance of those relationshipsembedded in a notion of the land as epistemology—-for all who come to live, and therefore be a part of, these lands.

Valerie impressed this upon her audience at the Wild Salmon Cookout.

That's how important this is for us. For thousands of years, and some people say since the beginning of time, we have organized our lives around the salmon nation, the salmon people. And so when I heard of a corporation taking our cultural and intellectual sacred gifts and putting it in a laboratory, splicing it with an eel and an Atlantic salmonthree species that if they were in a tank together would never reproduce another third kind of species, I was really alarmed.

She took time to articulate how the salmon are among the most important and powerful teachers to her people.

I was also taught that the salmon people ... and for Coast Salish people the most powerful teachings [are] those that are given without a spoken word. So not what I'm doing here today where I'm telling you what I know about Coast Salish foods and what it means to me and my people, but that we witness things on the landscape. And then we ask ourselves how us pitiful humans might be like the cedar tree, might be like all of the tree people, how they stand together, take root, and hold the earth together for those who come in the future, standing side by side in all their diversity and abundance. How it is that we might be like the salmon people, who upon 
leaving their ancestral rivers, journey out into the ocean sea, exercise, go on this odyssey, fortify their bodies with rich minerals and nutrients, and then return to their ancestral homes and give their life for the land and all that dwells on it. How it is that they are these relentless advocates to be medicine for the land. And so, us Coast Salish witness this return, and think how we pitiful human beings might be medicine for the land like the salmon.

When Roger Fernandes spoke, he shared a traditional Puget Salish story about Salmon Boy. The story of Salmon Boy describes a naughty young man who is changed by an experience in which he finds himself living with the salmon people under the sea for a time, later returning to his people to relay that what people do on the land affects those who live in the water. Roger imparted how this story exemplifies the ongoing importance of storytelling as an emplaced mode of knowing, central to how diverse beings thrive together as and in places.

We must respect and protect the house of the salmon people. And this is what that little boy taught his people from the time he lived with the salmon people in their villages under the ocean. [...] Many tribes [from this area] tell a version of this story. [...] Within our stories we are taught so many things. [...] The cultures that tell us stories try to tell us things. In this story the salmon people are the center of the world. In the Transformer story, the salmon people are the first creation. So everything we do, then, to save the salmon, every small thing we do, is really important.

And this wonderful event talking about the salmon themselves, that conversation has to be had. But it can't be just the Western view of salmon-a fish that swims in the water that we catch and we eat and is an economic and nutritional resource. To the Native people they are much more than that. [...]

After this, Roger articulated what I, upon reflection, have come to see as exemplary of what I have observed to be a pattern of polite but pointed interposition and interjection in 
their collaboration with groups of non-Indigenous peoples plugged into the hegemonic legal regimes, ontologies, and mythologies of settler society. He went on, and I think it's worth quoting him at length,

I've never been to Paris, but I'm pretty sure I could figure it out when I got there. It's a lot like Seattle. You've got all these tall buildings and streets, and lights, and yeah [...] I can figure that out. But again, that's a model that does not conform to the environment. It is a model that makes the environment conform to it.

And so right now I think we need to rethink some of these things, and to do that, we need to listen to the old stories of the old people of certain lands, like this land right here, and learn from that.

Any future for human-salmon kinship on Coast Salish land, according to Roger and Valerie, will entail attending to Coast Salish memory. The focus for them is restoration, directing all of our mutual resources-Western science, Indigenous science, coalition building, storytelling, community organizing — toward that. This notion of restoration does not invoke the nature-culture binaries that Deleuzian and ontological plurality scholars seek to escape, but rather one that, unlike those scholars, specifically looks not simply to "worlding anew," but to restoring modes of human-nonhuman relating that settler colonialism fetters. 


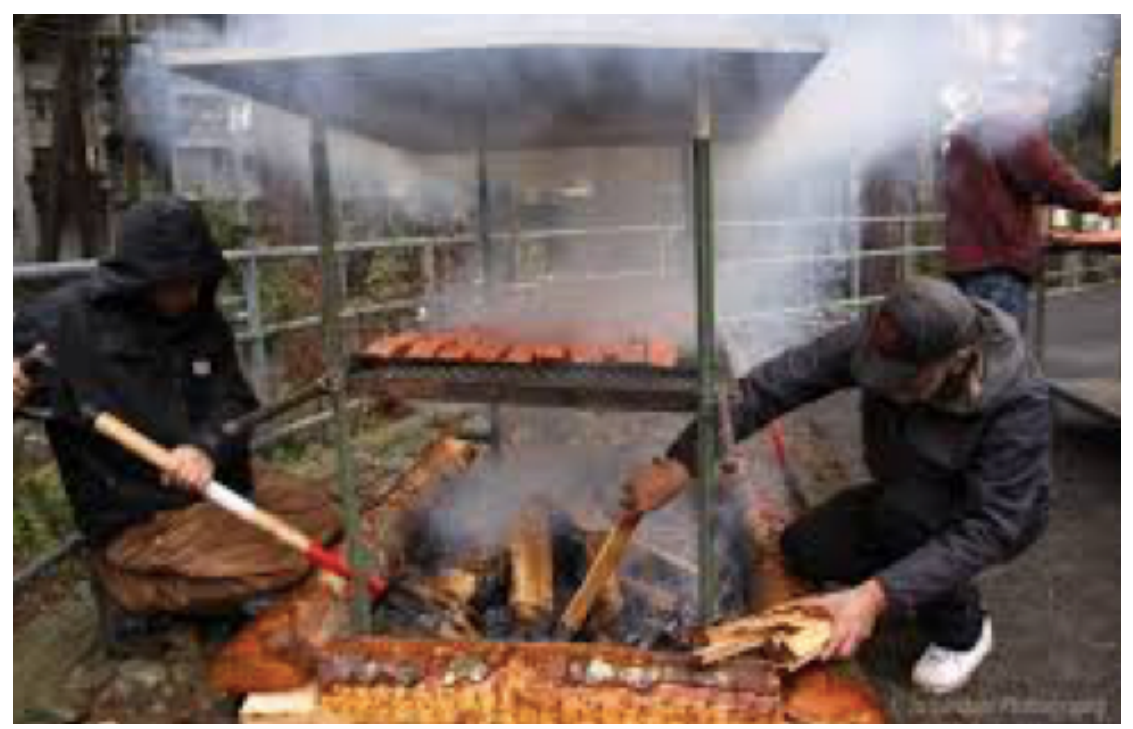

Fig. 4.3 Traditional Muckleshoot Fishermen preparing smoked salmon for the Wild Salmon Cookout event at watab?altxw (March 17, 2017).

\section{Toward a Geo-politics, Not Cultural Politics, of Salmon}

These kinds of pronouncements about the significance of the long relationships between Coast Salish people and salmon are often interpreted or framed in terms of the cultural importance of salmon to these groups of people. Yet recent work within anthropology attending to the discipline's relationship with Indigenous peoples troubles classical anthropological deployments of culture. Indigenous cosmopolitics scholars point to how these kinds of utterances invoke nonhuman beings (e.g. mountains, animals, atmospheres) in political life, and in doing so exceed modern politics. Marxian and classbased frameworks that have championed Indigenous rights in Latin American countries also constrain and discipline Indigenous politics, with implications for nonhuman life, and what kinds of more-than-human assemblages are possible, or not. According to Marisol de la Cadena, modern politics limit and obscure the horizon of Indigenous politics in Peru, in as much as they are rooted in what Latour called the "modern 
constitution," or the divide between Nature and the Human into separate ontological spheres (1993). This split is deeply institutionalized in the academy and has fractured knowledge production along the nature-society binary. Moderns, or those committed to the modern constitution, conceive of social and political life as fundamentally apart from the content of the biological sciences, for example, and they have conscripted social and political agency to human actors (a category hierarchized, in turn, by equating certain kinds of humans as innately closer to nature-e.g. women, Indigenous people). Modern politics are constrained by a commitment to this "Great Divide," obscuring the ontological politics at play in resource struggles, whereby not merely different beliefs about a singular, knowable nature are at stake, but the different ways humans, nonhumans, and the ways the relate enact different kinds of ecological assemblages, with more and less capacities for biodiverse thriving. This field of theoretical inquiry within anthropology seeks to affirm "radical alterity." It diverges with liberal multiculturalism, which extends rather than challenges the rootedness of modern politics in nature-society dualism.

In articulating the notion of 'refusal', Audra Simpson, however, troubles "culture" along somewhat different lines and to a somewhat different effect. Simpson is more concerned with how anthropologists, in ways that emerge from North American "salvage anthropology," have fetishized culture as a site of difference. Anthropology is rooted in ethnologists' search to document the cultural differences located in Native American societies before their (putatively inevitable) disappearance, assigning notions of tradition and purity to the concept of "culture." Simpson explains how this 
deeply controlled canonical approach to 'culture as the pure,' 'culture as tradition,' 'culture as what is prior to settlement' disavows or pushes away its context of articulation: the political project of dispossession and containment, as it actually works to contain, to fetishize and entrap and distill Indigenous discourses into memorizable, repeatable rituals for preservation against a social and political death that was foretold but did not happen (2014, 99).

In 'its theoretical and analytical guises 'culture' is defined in anthropological terms most consistently by its proximity to difference, not its sovereignty, its right to govern, to own or to labor" (Simpson 2014, 101). Some of the ways Simpson critiques liberal multiculturalism and longstanding anthropological methodologies parallel shifts scholars of Indigenous cosmopolitics are making. She is critical of how culture has been "defined against the sameness and omniscience of a stable ontological core, and unquestioned 'self' that defined that difference (and thus 'culture') for a readership, one that corresponded to a metropole and to a colony, a self, and an other" (ibid.) Simpson's critique of the stability of ontological sameness echoes the premise of those exploring ontological politics and pluralism. Yet Simpson is less interested in attending to "radical difference" than accounting for what this epistemology has produced in settler contexts, gesturing toward new political possibilities and futures by highlighting the pre-existence and ongoing-ness of Indigenous sovereignty and governance in the face of settler colonial structures that have attempted, but failed, to eliminate them.

Simpson's work allows and challenges anthropologists to approach Indigenous research partners and questions around Indigeneity in different, more accountable ways. She elaborates the notion of refusal. 
One way the Simpson's conceptualization of refusal aligns with de la Cadena's Indigeneous Cosmopolitics resides in the critique of liberal multiculturalism. For de la Cadena, liberal multiculturalism extends, rather than challenges, the modern constitution. For Simpson, liberal multiculturalism retells the myth of settler inevitability and futurity, framing inclusion within the liberal settler state as the desirable goal. Liberal multiculturalism frames Coast Salish difference with regard to salmon as cultural ideas should be "accommodated" or "respected" as much as possible by settler-states, Western science, and capitalism under the sign of equality and diversity. Yet qua being a settlerstate, the sovereignty of Indigenous land and life can only be held up so long as it does not stand in the way of settler, capitalist desires of accumulation.

In contrast to a multicultural politics that seeks to formally recognize the cultural distinctions and rights of Indigenous peoples, Audra Simpson seeks to make legible an alternative: the politics of refusal. Refusal, constitutes "a political and ethical stance that stands in stark contrast to the desire to have one's distinctiveness as a culture, as a people, recognized. Refusal comes with the requirement of having one's political sovereignty acknowledged and upheld, and raises the question of legitimacy for those who are usually in the position of recognizing. What is their authority to do so?" $(2011,11)$.

Coast Salish engagements with the specter of genetically engineered salmon are an extension of Coast Salish peoples' practices of asserting sovereign relations to their lands (as living, relational, and constituted by diverse agents) in the face the ways settler geographies and economies continue to contain or eliminate Indigenous life and land claim. 
In her ethnography of salmon aquaculture in Norway, Marianne Lien troubles the category of "wild salmon" in ways that resonate with how my Coast Salish research partners frequently feel the need to qualify their collaborations with non-Indigenous environmentalists and food actors. Coast Salish relationships with the salmon people, and many other nonhuman people, is not predicated on separateness or preserving wilderness, as Valerie as explained, but systems of reciprocity, obligation, and co-species practices. Lien's ethnographic work on human-salmon becomings has, moreover, put her into conversation with Charles Menzies and Ben Colombi, whose own ethnographic work, respectively, attends to Indigenous-salmon relationships in what is today Canadian British Columbia and the Columbia River Basin in the Northwest US — with places and people that are closely connected to my own research site (see Colombi 2012). In this engagement and collaboration, she turns her attention, she explains, not as much to how differently located human-salmon ethnographies might "serve as a guide for better governance" across time and space than to how they provincialize wilderness and its relationship to an ontology organized by a nature-culture divide (Lien in Colombi 2012, 219). She describes this as integral to her development of a postcolonial anthropology, which must make an effort to work at the edges of ontological mononaturalism and the entities and concepts it takes for granted, so as to avoid erasing [...] differences that may serve as templates for alternative futures" (Lien in Colombi 2012, 239). She finds in Colombi's and Menzies' work examples that trouble the assumption "humans represent a threat to salmon," revealing, rather, that "humans have sustained salmon and contributed to the proliferation and well-being of both" for much longer than aquaculture or the notion of wild salmon have existed (Lien in Colombi 2012, 238). 
I want to hold onto and build on Lien's project. My own work on this topic leads me toward suggesting a way of adding to, or reframing, part of the thoughtful discussion she generated around the quick rise of salmon aquaculture. This stems in part because I found myself navigating two areas of scholarship where pointed divergences are being articulated in my engagements with the secondary literature on salmon farming. It also stems from how my own research attuned me to sentiments and practices that complicated my understanding of and commitments to these literatures, their attendant politics, and what we mean and what is meaningful about aligning with, enacting, or committing to decolonization through them.

Lien describes herself as "closely engaging" material semiotics and actor-network theory (ANT) in her salmon ethnography, approaches associated with science and technology studies (STS) and that are specifically concerned with the materiality of social life. This area of scholarship is especially influenced by Bruno Latour, Donna Haraway, Michael Callon, Annemarie Mol, as well as Lien's close colleague, John Law. The concern here is less with matter, per se, than the kinds of relationships, connections, or agacements ${ }^{9}$ between entities that continually shape and reshape the materiality of all constituents that together form, per Deleuze and Guattari, an assemblage. What is significant in this conceptualization above all is, as in semiotics, relationality. In coining the term 'material semiotics', John Law described it as an "empirical version of poststructuralism" (Law 2008). It is a means of drawing attention to the productive qualities of situated practices. As a methodology and an approach to knowledge production,

\footnotetext{
9 "Agacement" is the world used by Deleuze that has been translated into English as "assemblage" (See Philips 2006). Lien uses the term in her book, "Becoming Salmon: Aquaculture and the Domestication of a Fish" (2015).
} 
material semiotics involves a departure from other empirically oriented social sciences that put forth normative critiques of what is being examined. Instead the aim is descriptive, particularly with regard to "how entities come into being in processes marked by material heterogeneity and contingency" (Beetz 2017, 8), thus described as becoming/s. Entities are conceived as "relational effects of materially heterogenous 'networks' (or assemblages, or association), which are themselves products of processes" (ibid.). This involves an explicit suspension of the binaries modernity proliferates (human/nature, subject/object, body/mind) and a repudiation of reifications, including of "capitalism." Often written as narrative, this scholarship tells "stories of how human and non-human entities form" assemblages in ways that emphasize the liveliness, agency, and sociality of non-human entities that, as such, are classically precluded as agentive or as participants in social life or "society." Material semiotics and ANT scholars instead attempt to capture how agency is dispersed across heterogeneous entities (see Beetz 2017, 9) - in the case of Lien's research, salmon, humans, net pens, commodity chains, fish pellets, and other technologies. Thus material semiotics are associated with post- or non-human/ist philosophies in as much as it supposes that "we have never been human," but rather that humans, like all other entities, are shifting relational effects co-constituted by and with many other entities. In developing a vocabulary that helps to achieve a way of conceptualizing "otherwise," scholars have employed the terms actants, quasi-subjects, cyborgs, and monsters (Beetz 2017, 13). For John Law, monsters are those entities brought to life by way of "outrageous and heterogeneous collage" $(1991,18)$.

Lien foregrounds these methodologies and approaches in her work on salmon, including her intention to suspend the binaries ossified in the category "wild salmon," her 
purposeful avoidance of reifying capitalism, and her attention to situated human-salmon becomings. For Lien and others, part of what is meaningful about this and closely related approaches is that they are de- or post-colonizing in as much as colonization (or modernity-coloniality) entails the universalization of modernity's ontology—-"the Great Divide," which operates in ways that obscure and suffocate ontological difference and the ways life flourishes and is enacted across many shifting and multiscalar spaces. Only in pushing ourselves to think "at the edges" of the ontological premises we have inherited from modernity can anthropologist hope to participate in a "postcolonial anthropology at home" $(2015,19)$.

One might get a deeper sense of what Johannes Beetz states that material semiotics scholars are "largely united in a kind of anti-critique and anti-Marxism" (2017, 20) by reviewing Bruno Latour's 2004 article, "Why Critique Has Run Out of Steam.” Here, Latour says he wants to retrofit and reorient the critic's tools away from that which debunks, and toward a kind of "care and caution" to the way things are constituted by gatherings. "The mistake we made, the mistake I made," Latour elaborates, "was to believe that there was no efficient way to criticize matters of fact except by moving away from them and directing one's attention toward the conditions that made them possible" (231). Drawing from Haraway, Latour here exhorts that the "critical urge" ought to be transformed toward "the ethos of someone who adds reality to matters of fact, and not subtract reality," in other words, to reconsider our preponderance as critics with antifetishism (232). "The critic," Latour suggests, "is not the one who debunks, but the one who assembles" (246). 
As we saw earlier in Ashely Dawson's work on biocapitalism, scholars who continue to see historical materialist critique as having necessary transformative and emancipatory effects can become frustrated with or dismissive of a conceptualization of materiality that instead of pointing to the material conditions that organize systems of exploitation (i.e. the capitalist mode of production), would first dissolve any such thing into diffuse associations. While Lien, for example, clearly sees her work as entailing a kind of politics (whereby she invokes postcoloniality), historical materialists like Dawson see a kind of anti-politics in material semiotics, ANT, multispecies anthropology, and similar literatures. Historical materialists feel that Deleuzian and post-Deleuzian materialists "have little to say about capitalism, exploitation, or ideology" (Beertz 2017, 20).

Both Marxist materialism and material semiotics posit that to be material entails the capacity to make a difference, and involves some measure of durability that comes from some sort of relations. For both, materiality is coterminous with sociality. Johannes Beetz, however, points to a crucial difference in how historical materialists and material semiotics scholars conceptualize materiality in that for the former, practices themselves are considered material, whereas for the latter what is of interest is how practices produce materialities (2017). The materialism of Marxians, of course, derives from the assertion of the primacy of materialism over idealism. This was not, for Marx, a matter of reducing things to physical matter, but to foreground a theory of practice. In this sense, both historical materialists and material semiotics scholars emphasize the processual quality of materiality. Yet, again, Marxians are concerned with the materiality of practice itself, where material semiotics is concerned with the materialities practices make. 
The point for Marxians is to unpack the naturalized status of material conditions so as to emphasize the difference people can make within structures - it allows us to see the materiality of ideology, social facts, beliefs, and rules as material qua practice. However, in material semiotics, these kinds of materialities are "denounced as inaddmissable reifications" (Beetz 2017, 23). In pointing to this difference, Beetz acknowledges that such materialities "can appear as reified things if they are presented as static things that are just assumed to exist." Yet "at every point, the black boxes of these materialites can be opend and presented in their complex processual reality" (23).

Finally, for Marxians, History is material. Material semiotics scholars balk at "History with a capital H," in favor of conceptualizing "diachronic processes and social order made more or less durable and lasting with the help of materials" (Beetz 2017, 23). Beertz asserts this entails downplaying struggle in favor of "the associations in flux that we find we follow material heterogeneous actors around" (ibid).

I am struck by how Coast Salish opposition to genetically engineered salmon maps onto to these scholarly tensions in a complicated way. For one, there is a sense of (historical) struggle against the settler state and its imbrications with global capitalism that seems better captured by Marxian critiques of biocapitalism, and which is deemphasized in Lien's work. Yet Lien develops a very intricate vocabulary and helps to sensitize her readers to ways of apprehending human-salmon relationships away from the ontological divides and (potentially violent) boundary-making bound up with wilderness and the category of "wild salmon."

I want to argue Indigenous critiques of settler colonialism help us think through these tensions productively, including the kinds of breaks Indigenous scholars articulate 
in their own contemplative engagments with Deleuze and Marx. In Chapter 2, I described how the importance of (long) memory complicates both Jodi A. Byrd's and Eve Tuck's relationship with Deleuzian scholarship. For Byrd, this stems from an insistence, by her and within critical Indigenous studies, that despite poststructuralism's cautions against the original and orginary, "there must be the possibility of the originary in the new world, and that it is located within the historical experiences of new world colonizations, genocides, and violences. There is a long line of continuity between the past and the present that has not been disrupted despite the fact that the stories we tell may or may not acknowledge that continuity" (2011, xx).

In Lien's work, what is left out of her exceptionally sophisticated work on and away from the ontological traps of wilderness is that wilderness specifically emerges out of US settler colonialism and its requirement to eliminate Indigenous people, socionatures, epistemologies, and sovereignties from the land. As we know, the wilderness logics and environmentalism that are responsible for the creation of national parks and other nature preserved began in the US and were subsequently transported (transited) to other places. In Lien's work, the relationship between Indigenous sovereignty and histories of human-salmon relationships exist as examples among many in which we find salmon has never been wild. To read her work alongside Byrd is, I think, to emphasize that wilderness originates in North American settler colonialisms, and thereby situates the relationship between Indigenous sovereignties and the "monsters" wilderness produces at the center of the conversation.

Both Byrd and Tuck articulate a tension in wanting to hold onto all that is gained by a focus on becoming against being, while cautioning that fluidity, relativism, and 
becoming can be and have been all too easily weaponized (intentionally and unintentionally) against Indigenous efforts to "reinforce our own self-determination and sovereignty when our primary relationship to the Whitestream USA has only served to tell us we are already dead" (Tuck 2010, 647; see also Grande 2004). Both express the need to make more space for memory, specifically the long memories of Indigenous peoples, in these areas of theorization.

I want to ask what emerges when we put John Law's concept of monsters-which ask us to reconceive of agency dispersed across heterogeneous entities, all of which are relational effects - with Eve Tuck and C. Ree's definition of monsters, hinged on a valuation of history and memory that has not figured very prominently in material semiotics. They put forth a discussion of monsters as those who have "been wronged and seek justice;" those who interrupt as soon as "an injustice is nearly forgotten" (2013, 649). Monsters are attached to the denial of "people who deny the persistence of settler colonialism" and are thus "like the heroes in American horror films, astonished that the monster would have trouble with them" $(2013,649)$.

I submit that there is an emphasis in Coast Salish refusals of settler colonial and capitalist death-making that not only asks us to provincialize wilderness for the sake of imagining worlds otherwise and worlding anew, but that very specifically entreats those living on Indigenous lands within settler societies to be far more accountable to the longestablished socio-legal orders that made these lands and waters appear so Edenic to EuroAmerican foreigners in the first place.

Jodi A. Byrd asserts that "the future anterior of $[\ldots]$ a world that exists outside the cruel optimisms and violences constitutive of liberalism's very structures must also be a 
future in which indigenous peoples will have been and will remain decolonized, if there is to be any hope at all" $(2011,38)$. I take this as a site in need of further engagement, care, and theorization: Byrd's assertion that worlding anew is not only itself not, per se, decolonizing, but is definitionally what the settler colonizer does. As we "world otherwise," specifically away from colonialism, that imaginative and practical work must entail, center, attend to, and elaborate ways for those living on Indigenous lands to be accountable to Indigenous sovereignties. 


\title{
CHAPTER 5: Landscape Fire and (Un)Forgetting: How Burning in the Salish Sea Prairies Points to an Ethic of Solidarity Beyond the Commons
}

\author{
Every time we carry an eagle feather, that's sovereignty. \\ Every time we pick berries, that's sovereignty. Every time we \\ dig roots, that's sovereignty. \\ I keep it all focused here on what the now keeps forgetting

\begin{abstract}
Traditionally, we would use burning methods to manage our berry meadows; now we have Smokey the Bear who tells us that fires are terrible.

Valerie Segrest (Muckleshoot)

Soil-tilling animals like pocket gophers also help, but us getting out here and harvesting camas means that next year there will be even more.
\end{abstract}

Billy Frank Jr. Angie Morrill, Eve Tuck, and the Super Futures Haunt Qollective

Aleta Proste (Squaxin Island)

The early-morning August sun permeating my blinds and a phone call stirred me out of a dream before my alarm had the chance. I brought my phone close to my eyes. "Joyce" appeared on the screen. We had plans to carpool together from Seattle to Greenwater, a small town in the western Cascadian foothills in central Washington. From there we would caravan with the rest of our group into the mountains to harvest huckleberries in the Muckleshoot Tamanamus Forest. "Does your car have All Wheel Drive?" she asked. "No," I replied, suddenly becoming un-soporific. "Do we need an AWD vehicle?"

By late morning we arrived at a lodge-themed rest stop in an AWD pickup truck that Joyce had managed to borrow last minute. The familiar faces of the women I work with through Tend, Gather, and Grow came into view. They greeted us in the parking lot 
with patient, enthusiastic smiles as we pulled up more than an hour late. We promptly caravanned to a campsite Valerie had picked out close to the Green River on Muckleshoot land, where we rearranged ourselves into fewer cars.

I jumped into Valerie's truck. She drove speedily as we ascended along increasingly steeper, narrower, and rockier dirt roads. My fear of heights kicked in as we took successive hairpin turns - the shoulder of the road disappearing until I could only see plunging slopes moving past my window. Valerie drove this stretch like it was habit, using the rearview mirror to make eye contact with Joyce in the backseat as we wound up the mountain. To calm my nerves, I shifted my gaze upward to catch the contours of the forested mountain expanse coming into view. By the time we parked, we had reached an elevation of approximately 4,200 feet. I stared at the undulating land stretching along the horizon, the most sweeping view of the Cascade Mountain Range I had seen since coming to the Pacific Northwest. Turning around to familiarize myself with our harvesting site I noticed two Muckleshoot families already picking berries. Elizabeth and Mariana had not hesitated before scattering into the sloped meadow to start picking. A new reticence grabbed me. It was a feeling akin to being introduced to a friend's family for the first time. I was new and unfamiliar in a place abounding with kinship and knowing. Encouraged by the warmth of my new companions, I grabbed my milkcontainer-with-the-top-cut-off and walked toward the meadow to introduce myself to the most prized plant in the forest, big huckleberry. 


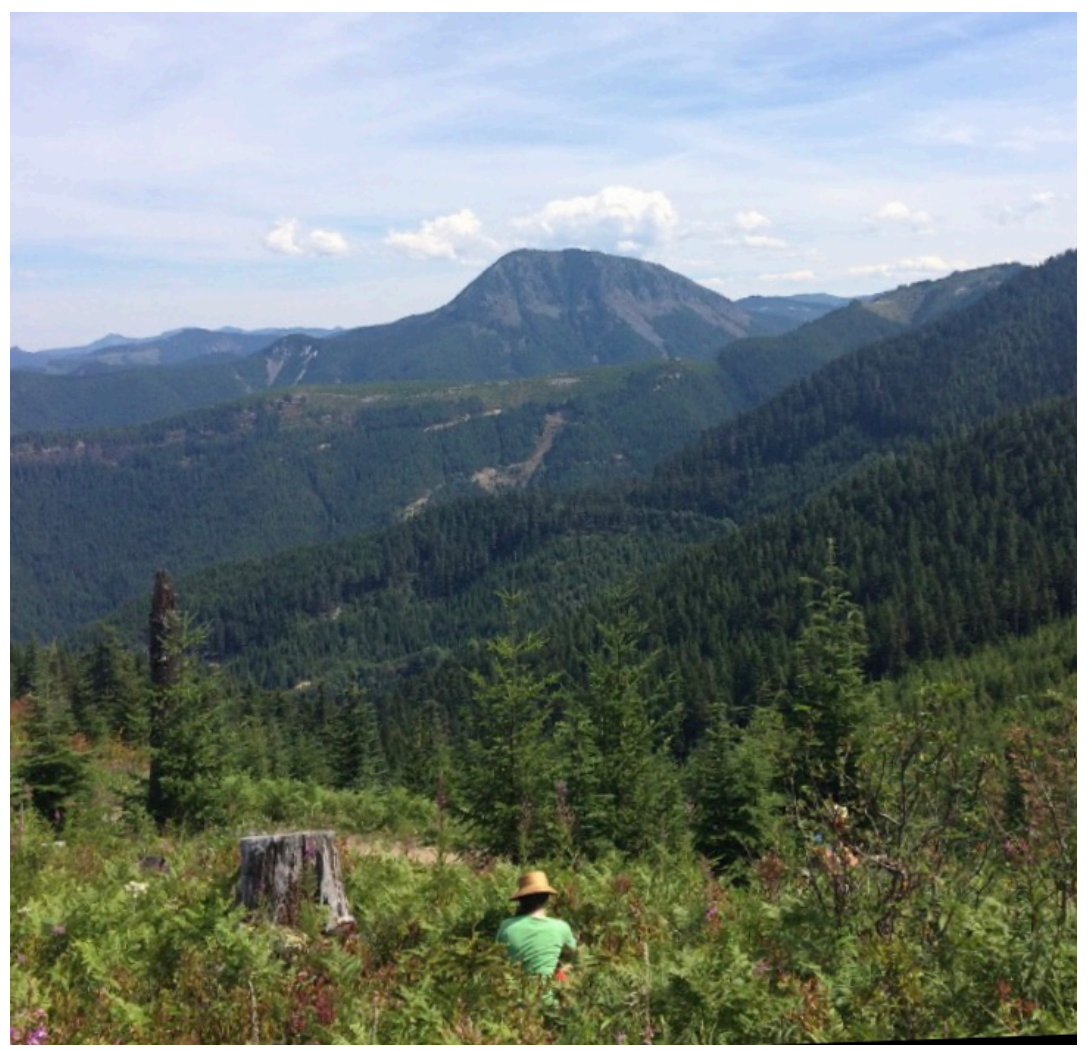

Fig. 5.1 Elise harvest huckleberries in a meadow within the Muckleshoot Tamanamus Forest. (August 13, 2016)

Huckleberry picking is not for the listless. The harvesting season for big huckleberries in the Washington Cascades is short, beginning in mid- to late August through mid-September depending on elevation and frost (Potash 2008). Elizabeth and Elise averred that mountain huckleberries are most ripe and sweet in late August. Each plant person we discussed, contemplated, and built lessons around in Tend, Gather, and Grow enjoyed the affections of the Coast Salish food revitalizers in our group. Yet after experiencing a year's worth of pedagogical plant work, huckleberry is conspicuous for drawing out unmatched levels of sheer joy.

The ancestral and customary sites where Salishan peoples have harvested huckleberries and tended berry meadows over hundreds of years currently spans a 
patchwork of differently owned and managed lands, from preserved wilderness parks, privately owned lands for timber extraction, to tribal reservation lands. The Muckleshoot purchased what is now the Tamanamus Forest in 2013 from a partnership run by Bostonbased investment manager Hancock Natural Resource Group, reacquiring an "important part of the tribe's homeland"- 96,3007 acres of forest spanning King, Pierce and Lewis counties (Cross 2013). Tribal Council Chairwomen Virginia Cross described brining this land into tribal ownership as "the realization of a long-held goal of our people" (ibid). That it is comprised by swaths of long-tended huckleberry meadows and harvesting grounds plays a significant role in in its importance to the Muckleshoot. The reacquisition of the forest is just one example of how huckleberry meadows have brought the Muckleshoot and other Coast Salish tribes into various dealings, conflicts, legal struggles, and collaborations with extractive companies, public land managers, and park users over the last two decades.

It is worth disclaiming that the word 'access' entails a kind of compromise with settler modes of legibility in terms of relaying what is involved —all that is at stake—in the efforts Salishan people make to navigate the constellation of disruptions, displacements, and containments that erode their deep time relations to huckleberry and other cultivated plant landscapes under settler colonial governmentality. Valerie often points out that her people's ceding of land was contingent upon guarantees without which her ancestors refused to sign treaties with the U.S. government—-that their people could hunt game, catch fish, and harvest roots and berries at all accustomed sites in perpetuity. Valerie argues that the Medicine Creek and Point Elliott treaties, the fulcrum upon which the U.S. has any legal claim to these lands, are premised on tribal food sovereignty. 
Tribal food sovereignty entails a geography of kinship relations, not simply access to (healthy) food qua an environmental "resource" or "benefit." Still the word 'access" permits translation. Tribal access to these harvesting grounds has been compromised in more ways than the immobilizing effects of property laws and borders. Coast Salish tribes articulate distress over the degradation and mismanagement of these landscapes and their (ecological) integrity. These concerns have as much to do with the environmental impacts of development and extractive commerce as it does with the prohibition of anthropogenic disturbance - particularly via burning — as these longcultivated landscapes became state-protected wilderness areas.

Fire brings huckleberry meadows into propinquity with 'Garry oak' meadows and camas prairies, despite representing different landscapes, harvesting seasons, and foods. Consider how Valerie slips from one to other in her discussion on the kinds of dynamics that work against tribal food sovereignty.

Food sources such as camas prairies were so abundant here in the Northwest, they could be what we call nowadays a community garden. It was a place where several families would gather and dig camas bulbs every year and camas was, next to salmon, one of the most traded items in the Northwest at one point. The prairies were so abundant that you could walk through the prairies from Canada all the way into northern California, and now we have less than three percent of them intact. So development has been a huge barrier, but also there are barriers in how to manage the remaining prairies and also how to manage our huckleberry meadows. [...] our huckleberries and our camas fields haven't been burned in a very long time, and they need to be managed and continually harvested to continue growing (emphasis mine, 2018).

For thousands of years, regimes of controlled burning produced and maintained huckleberry meadows and camas prairies amid the region's expanses of dense conifer 
forests. Anglophone settlers journaled about their awe for these "pristine" landscapes when they first arrived to Puget Sound, mistakenly—and with unacknowledged tragic irony—describing them as "well stocked" by "Nature" (Vancouver 1984). It is only in recent years that tribes in Washington have begun to find partners open to approaching these diminishing landscapes as something other than Nature to be exploited or conserved.

In this chapter, I illustrate how efforts to revitalize huckleberry meadows and camas prairies as Coast Salish fire ecologies reveal extraction and conservation / exploitation and commoning to be more isomorphic than we might imagine. In doing so, I put Indigenous critiques of settler colonialism into conversation with critical food studies scholarship in a way that allows me to make the following argument: While much of the critical food studies literature, along with a broader critical theory matrix, treats them as such, neither anti-capitalism nor a Deleuzian ethic of 'worlding anew' are, per se, synonymous with decolonization, a term that is over- and mis-used in ways that have abstracted it from land/s (Tuck and Yang YE2012AR). As theoretical orientations concerned with emancipation and livability, the anti-capitalist notion of 'the commons' as well as Deleuzian-inspired scholarship emphasizing 'worlding anew' are often elaborated in alternative food system work (both in scholarship and activism) without acknowledging the ways that they rehearse settler logics and safeguard settler futurity.

By examining recent work Coast Salish food revitalizers are doing and the partnerships they are forging - largely through their articulations of tribal food sovereignty—in this chapter I am able to illustrate how these dynamics model a politics 
and ethics of solidarity beyond prevailing emancipatory concepts in North American social science and activism within and beyond alternative food work.

\section{Fire Ecology in the Cascades Before, During, and After Settlers}

In a letter to Robert Boyd marked May 28, 1996, anthropologists Jay Miller wrote about taking a "vanload" of Methow elders into the Methow Valley of North-Central Washington. He became confused when a woman began to cry. "She sobbed," he wrote, grieving, "when my people lived here, we took good care of all this land. We burned it over every fall to make it like a park. Now its [sic] a jungle" (Miller 1996).

Twenty years later, I sat across from Valerie as we met to discuss possibilities for agroforestry in the Muckleshoot Tamanamus Forest. At one point in our conversation I mentioned that there has been increasing interest within the alternative food movement to “foraging." Striking a balance between politeness and baldness, Valerie allowed me to finish my thought before replying, "I don't like the word 'forage."” She continued, "it repeats the idea that we just grazed lightly on the land — that we didn't have our own forms of resource management."

Only in the last 20 years have anthropologists and ecologists begun to appreciate that Salishan and other Indigenous peoples living on both sides of the Cascade Mountain Range spanning what is now Washington State and British Columbia employed regimes of burning as a landscape cultivation tool. Inheriting notions of the region as uncultivated wilderness shaped by Anglophone explorers and colonizers in the $18^{\text {th }}$ century, Coast Salish ethnographers have largely continued to miss an entire complex of land-tending and plant landscape cultivation techniques that maintained rich and intricate food systems 
across the region-including anthropogenic burning, that were productive of camas beds, root gardens, huckleberry fields, oak savannahs, tule flats, shellfish gardens, and the fulsome salmon fishery itself.

When George Vancouver encountered the coastal oakscapes long-maintained by Coast Salish people as the head of a British expedition to the American Northwest between 1791 and 1795, he was so impressed by how the

surrounding country [...] presented a delightful prospect consisting chiefly of spacious meadows elegantly adorned with clumps of trees; among which the oak bore a very considerable proportion [...] In these beautiful pastures [...] the deer were seen playing about in great numbers. Nature had here provided the well-stocked park, and wanted only the assistance of art to constitute that desirable assemblage of surface, which is so much sought in other countries, and only to be acquired by an immoderate experience in manual labour (Vancouver 1984, emphasis mine).

It is these very parklike forests and grassland habitats that are today disappearing across the west coast after more than a century of fire suppression and lack of tribal management (Anderson 2005). Yet Coast Salish ethnography has until very recently classified Native Northwest peoples as foragers and hunger-gatherers-erroneous anthropological labels connoting a "hand-to-mouth existence," and a kind of default conservationism that left no "lasting human imprints" on the environment (Anderson 2005). Anthropologists have done their part in extending the misrecognitions Anglophone colonizers made, extricating Indigenous humanity from the land along with concomitant claims to land title. They described Native Northwest Coast societies as beneficiaries of naturally copious salmon runs, who enjoyed a variegated diet as foragers, hunters, and fisherfolk without substantial effort or impact on the environment. Alfred 
Kroeber and his contemporaries proclaimed Native people of the Northwest to be "a wholly non-planting and non-breeding culture" $(1962,61)$. Even as Franz Boas subsequently worked to counter the evolutionary model of cultural development, he propounded the orthodoxy that the food economies of Native Northwest peoples lacked plant cultivation (Turner 2013).

In the wake of the Homestead Act and Land Donation Act which brought waves of Anglophone American settlers to "Oregon Territory," leading up to and after Washington State incorporation in the Union, "accounts of indigenous plant use remain[ed] superficial and tied to the biases and agendas of the colonial project" (Turner and Deur 2005). Settlers saw the people inhabiting these lands as subsisting from it with minimal labor. Nineteenth century writers opined "of agriculture they are quite ignorant [...] they have no aboriginal plant which they cultivate" (Brown 1873-1876, 50). These notions informed justifications of territorial dispossession and nullifying Indigenous claims to land title. Land Commissioner Gilbert Sproat wrote in 1868

We often talked about our rights as strangers to take possession of the district ...The American woodmen...considered that a right in the soil which these natives had as occupiers was partial and imperfect as, with the exception of hunting animals in the forest, plucking wild fruits, and cutting a few trees...the natives did not in any civilized sense, occupy the land (Sproat 1868 [1987], 8).

The ways settler fire suppression has transformed the landscape constitutes a recursive, nonlinear dynamic of territorial dispossession in US Northwest. On one hand, the treaties that Native peoples across what is now western Washington "negotiated" with governor Isaac Stevens, while ceding massive swaths of land to the U.S. government that 
confined and relocated them onto reservations, could not be finalized unless governor Isaac Stevens guaranteed they secured access to their traditional foods, regardless of reservation boundaries. Stevens "repeatedly assured them" the treaties outlined those guarantees, knowing the assembled chiefs would "never sign the agreement" otherwise (Fisher 1996, 193). "We do not want you to agree not to get roots and berries and not to go off to [hunting grounds]" he told them. "We want you to have your roots and to get your berries, and to kill your game" (ibid). The understanding on the part of Native negotiators was that the treaties protected their people's capacity to maintain their food systems on the land as they saw fit in perpetuity (Fisher 1996). Yet not only did settler land management regimes increasingly enforce de jure and de facto policies of fire suppression that diminished these landscapes, but settlers and settler-state actors constantly found ways to undermine Indigenous claims to these rights of movement and use on the land. In turn, this exacerbated the loss of tribal management of these landscapes, further submitting them to ecological alterations unsuitable to nurturing berries, root vegetables, and other socially significant plants.

In as much as Coast and Interior Salish peoples used fire to shape and relate to the land, it was primarily to cultivate food landscapes. Controlled burning produced and sustained some of the most valued food plants in Salish country, particularly huckleberries and camas. In this section, I concentrate on huckleberries.

sweda?Xac: Big Huckleberry and Cascadian Mountain Berry Meadows

While there are nearly two dozen varieties of huckleberry that grow at various elevations in the forests of the Cascade Mountains, big huckleberry (vaccinium 
membranaceum, sweda?Xac in Lushootseed) stands out as the most prized. It is also known as mountain huckleberry, thinleaf huckleberry, and black huckleberry. Big huckleberry is an early seral shrub native to western North America that grows in alpine and subalpine environments (between 3,000-6,000 feet) in the meadowlands of spruce and pine forests. Seral communities exist at a kind of middle stage of ecological development, consisting of species that are likely to be taken over or minimized as other species tend to dominate, thus requiring some form of disturbance to be sustained. Using ethnohistorical and archaeological methods, researchers have reconstructed various regimes of controlled burning across Cascade mountain meadows, their effects on landscapes, and the effects of fire suppression over the last century. On both sides of the Cascadian slopes, Salishan peoples burned fields to maintain the early-seral state of huckleberry shrubs, control encroaching conifer trees, put down a layer of fertilizing ash, and to repel pests (Martin et al. 2008, 10; Lepofsky et al. 2005). Likely due to lightning generated fires in the mountains, big huckleberry adapted to sprout after fire, while "storing nutrients released from burning" (Martin et al. 2008).

North Cascades ecologists now understand that Native burning regimens "acted as the disturbance agent that created the early successional conditions that favor big huckleberry growth, spread, and berry production" (Ruchty 2008). The forest succession attendant with fire suppression since the start of the $20^{\text {th }}$ century, including active fire suppression policy, has resulted in the closing of canopies that choke off light from the understory, quelling shrub growth (ibid). While the declines are not as stark as the decimation of Garry oak meadows that sustained camas prairies in coastal lowlands, 
National parks ecologists began to acknowledge declines in productive big huckleberry habitat in the early 2000 aughts.

Big huckleberry constitutes one of the most sacred and important foods for many Salishan peoples. In Yakama oral traditions, big huckleberry (wiwnu) is called the "chief" of all the berries," the "same as good words from the other world" (Fisher 1996, 186). In Tend, Gather, and Grow, Coast Salish food revitalizers described mountain huckleberry as one of the healthiest and most important traditional foods. The members of the Northwest Native Plants and Foods Collective propound the aphorism that "our food is our medicine." Yet huckleberry holds a special status as a medicinal food.

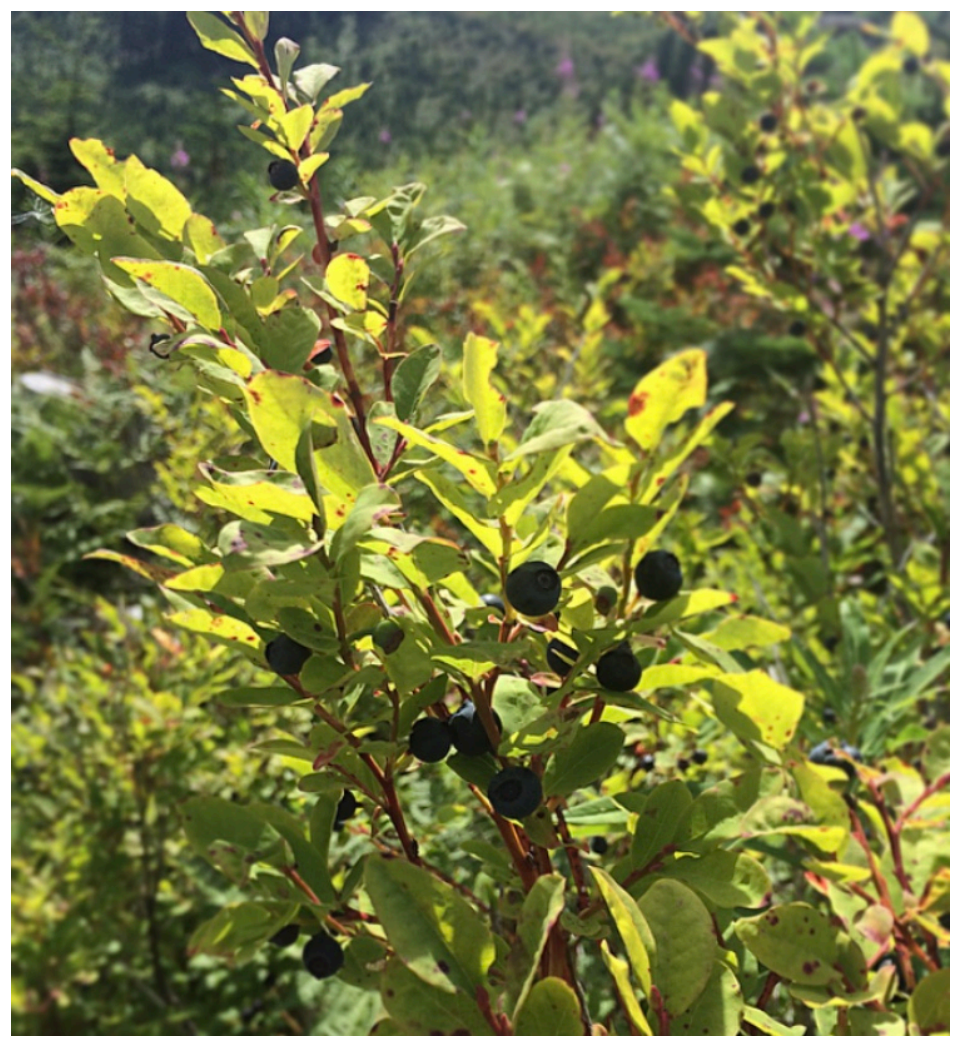

Fig. 5.2 Example of Big Huckleberry, from our day harvesting in the Muckleshoot Tamanamus Forest. (August 13, 2016) 
When Roger Fernandes of the Lower Elwha S'Klallam people visited one of our Tend, Gather, and Grow meetings in early 2016, he shared stories about several plant people, in excess of our focus on stinging nettle that day. After hearing the story of how nettle made the people strong, and of grandmother cedar, we listened to Roger share the Puget-Salish story of Huckleberry Medicine. It relays a time long ago when the beloved daughter of a family living along the waters of Puget Sound fell very ill. None of their traditional medicines were helping her to recover. The family called in doctors from different neighboring peoples, but the daughter only became more sick with fever and pain. The family was very worried she might leave them. She might die. The father prayed to the spirits and ancestors each night for guidance, and eventually a dream came to him. It taught him a song that he was to sing following the trails up into the mountain. When the time was right he would know to stop singing, and the medicine he needs would sit below him. The next day he followed the trails into the mountains singing the song. When he knew to stop singing he looked down and found a green plant with blue berries, and he knew this was the medicine. He picked the berries, brought them home, and made a juice his daughter could imbibe in her fragile state. She became better. As her health improved, she could now stomach to eat the berries. Her fever broke and the pain subsided. The people wanted to know about this medicine. The father explained the dream, the song, and plants. The people were skeptical. In the following days, a new dream came to the father. It told him the plant was the huckleberry, and that huckleberry is the blood of the earth. The plants themselves are veins of the earth. The people say that besides being a wonderful food, huckleberry is a powerful medicine that comes from the earth itself. 
Valerie and Elise often emphasize how huckleberry is associated with anti-aging and long life. Elise pointed to the high antioxidant levels of the berry-which prevent inflammation and protect against the effects of high blood sugar, including diabetic retinopathies, poor tissue healing, and kidney damage. Huckleberry has the unique quality among fruits—all of which contain natural sugars—of possessing a compound that lowers blood sugar such that the net blood sugar effect equals zero. It also contains a compound called arbutin, shown to counter the bacteria that causes bladder infections and urinary tract infections. Elise relayed that Coast Salish people used the juice from the berry as well as tea from the leaf to prevent and treat those infections. Valerie calls them "incredible anti-agers" and "long-life givers." She recalls stories "like that of my auntie who lived to be over 100 years old with a diet of berries and fish. [...] [Huckleberries] are high in fiber and vitamin $\mathrm{C}$ and $[\ldots]$ they actually help balance the blood sugar. So they're anti-diabetic in a way, and diabetes is such an epidemic in our community" (Segrest 2018).

Shifting Boundaries, Ecologies, Contestations, and Collaborations in the Berry Meadows Previously managed as privately-owned timberland, the Muckleshoot purchased the White River Forest from Hancock Natural Resource Group, renaming in Tamanamus. It is an anglicized form of "temanemes," a word from the old Chinook Jargon meaning "I believe our forest animals are our spirit power" (Muckleshoot Monthly 2014). Walking over to the huckleberry bushes in Tamanamus, Elise expressed her ironic gratitude that the cutting entailed by the timber industry actually worked in some ways to sustain huckleberry meadows by disturbing the ecology enough to maintain seral conditions and 
an open light regime. Without that ecological disturbance, forest succession would have diminished the huckleberry meadows in this forest expanse. Muckleshoot families now enter this harvesting ground without hassle. Still the majority of Salishan huckleberry meadows remain outside of federally recognized tribal territory.

Large swaths of Salishan huckleberry harvesting grounds span what are now preserved wilderness areas within the Gifford Pinchot National Forest (GPNF) and Mt. Baker-Snoqualmie National Forest. While U.S. National Parks have certainly functioned as sites of exclusion and dispossession for Native people in Washington State, they have in some instances served as spaces where Indigenous people have been able to foster a modicum of exception and forge surprising collaborations in asserting treaty rights to provisioning within a milieu of settler and settler-state antagonism. In 1932, at a time when settlers and federal agencies showed increasing resentment toward Native "subsistence" practices that interfered with settler desires for land, wealth, and comfort, Columbia National Forest (subsequently GPNF) rangers set aside nearly 3,000 acres of public land for Yakama use when "an army of unemployed non-Indians invaded the Yakama's berry fields" (Fisher 1996, 188). This arrangement, called the "Handshake Agreement," helped to guard the Yakama Nation's ability to maintain their relationships of reciprocity with the land. While the Yakama Nation was prohibited from using fire to manage these lands, this agreement "has afforded the Yakamas a degree of protection unknown on other national forests" (Fisher 1996, 189).

While the National Parks and Forests existing within Washington State increasingly developed relationships with tribes in ways that permit limited kinds of food provisioning on the lands currently under their management, it is only since the $21^{\text {st }}$ 
century that parks personnel have been open to talking with tribes about any sort of reintroduction of burning. In 2002, Muckleshoot tribal elders contacted the Mt. BakerSnoqualmie National Forest to articulate concerns about diminishing yields of big huckleberry and other plants used for tribal needs in government meadows (Martin et al. 2008). That outreach slowly developed into a collaboration between Mt. BakerSnoqualmie National Forest and Muckleshoot biologists alongside other local researchers, including Joyce, a University of Washington environmental anthropologist who would later work as a core Tend, Gather, and Grow team member. They organized "The First Annual Big Huckleberry Summit" held in 2007 on the Gifford Pinchot National Forest. Deemed a success, more than 80 people attended, involving participation from five tribes-Muckleshoot, Umatilla, Yakima, Warm Springs, and Snoqualmie (Martin 2008).

With the input from the Big Huckleberry Summit, the collaboration initiated a project area for a longitudinal study within the Mt. Baker-Snoqualmie National Forest to test the effects of reintroducing modified Indigenous land tending techniques. The research design built on oral histories of tribal members, the expressed need for accessibility to elders, and potential productivity based on ecological models (Martin 2008). While burning would not be introduced immediately as a result of trees being "too small to effectively support a broadcast burn," once the trees would eventually be removed to open the canopy, the experiment will entail small prescribed burns (Martin 2008). The collaboration also fostered a set of inter-tribal, inter-organizational, and interpersonal relationships and commitments to continue to share information (ibid). 
This work informed a subsequent effort by the Special Forest Products (SFP) program on the Gifford Pinchot National Forest in 2008 that sought to address concerns within the Yakama Nation about barriers to harvesting and the integrity of huckleberry meadows on national forest land in light of not only declining production but new competition on harvesting grounds, and the ecological effects of increased traffic in these areas. In a report prepared by Andrea Ruchty, a GPNF botanist, the program acknowledges that huckleberry fields are shrinking due to the decrease in "disturbance elements that once created or helped maintain suitable huckleberry habitat" (2008). The report also acknowledges the park's obligations to the Yakama via the 1932 "Handshake Agreement" and the Medicine Creek Treaty, in which the Nation "reserved the right of gathering of roots and berries in these areas" (ibid). While many of their traditional harvesting grounds have been diminished via succession due to fire suppression, the Sawtooth Berry fields near the Mt. Adams Ranger District have become an especially important area. These meadows have been diminished substantially since 1905 when they extended across 6,000 acres, yet the existing 1,500-2,000 acres constitute one of the most productive and well-used harvesting sites today.

One of the major complaints expressed by tribal berry pickers involves the increase in commercial demand for huckleberries, in particular that commercial pickers harvest the huckleberries before they are ripe in order to extend the life of the berries for the sake of shipping, shelving, and market longevity. The effect is that the most accessible berries have been picked before Native and recreational pickers come to the meadows to harvest. Elsie David, a Yakama Nation member, explained in an Oregon Historical Society interview that "Huckleberries are kind of a big issue right now with 
our people. We have to race now, because it's become a big commercial product. We're taught to wait until they're ready and feast. We need to pick with care, just like how any person would take care of a berry garden" (OHS 2007). One of the central concerns raised here is the depletion of the majority of more easily accessible huckleberries due to commercial pre-season picking limits tribal elders' ability to harvest. The Gifford Pinchot National Forest responded by instituting a new policy in 2005 that established August $15^{\text {th }}$ as the official start to the commercial picking season (Ruchty 2008). This only partially alleviated concerns, as commercial pickers continued to harvest early outside the Forest Service boundaries, and many continued to pick illegally within the Forest. Additionally, GPNF has banned rakes for huckleberry harvesting, as the Yakama Nation, Confederated Tribes of Warm Springs, and Muckleshoot Tribe are also opposed to the use of rakes because they damage bushes (ibid).

GPNF presents trends in commercial permit purchases to pick huckleberries and special forest products in the Forest as evidence that commercial demand has increased steadily (ibid.). GPNF points to "a growing cottage industry capitalizing on the allure of the exotic wild huckleberry in a variety of products, ice cream $[\ldots]$ teas, and coffee, as well as personal care products, such as lotions and soaps" (Ruchty 2008). The companies linked with huckleberry harvesting in GPNF, including Tillamook and Northwest Wild Foods, market their added value products through the narratives, identity scripts, and taste-making tropes of the sustainable agriculture-focused alternative food movementincluding the unquestioned "good" of local and placed-based consumption, organic production, and terroir. Tillamook advertises its long history as an agrarian local foods purveyor in the Northwest. As dairy company, it links itself to the settling of Tillamook, 
Oregon in the mid-1 $19^{\text {th }}$ century, where settlers discovered the environment lent itself to raising dairy cows. Tillamook emphasizes its origins in this history of settlement via small, family farm production as something it stays in keeping with, lending wholesomeness and righteousness to its foods (Tillamook 2018). Northwest Wild Foods advertises its products as coming from "the temperate Puget Sound and the rugged Cascade Mountains of the Pacific Northwest." It describes itself as "a small, family-owned company $[\ldots]$ that is dedicated to bringing you the rare and natural wild flavors of our region and beyond [offering products that are] sustainably harvested, Kosher and GMO free" (Northwest Wild Foods 2018). It grossed $\$ 750,000$ in frozen huckleberry sales in 2006.

In the SFP program report, GPNF acknowledged plans regarding huckleberry use and management must take into consideration that for the Yakama Nation, huckleberry is not valued as a commodity "to be valued purely on an economic basis," but rather a sacred food "more akin to a child than a dollar" (Ruchty 2008). Quoting Yakama participants in the 2007 Huckleberry Summit, the report aims to consider the Yakama claim that "plants and animals were the first people." It articulates a renewed commitment to work with the Yakama Nation to identify priorities for restoration and working as partners to steward huckleberry meadows on GFNP land.

In discussing the ways these recent attitudinal shifts on the part of public land managers have precipitated new kinds of partnerships with tribes, Valerie summarizes "we live in a time where our natural resources department in the state of Washington is looking at our natural resources and cultural resources now, which is great. 
They've made some compromises on burning issues, not quite what we'd like to see, but it's a start" (2015).

Resource exploitation and conservation mix strangely on national forest land, a form of power that now overlays Salishan geographies and their concomitant social orders and ways of relating to the land. It is both the commodification of huckleberries and their location within protected areas that contribute to 1) the inability of Coast Salish people to access their traditional and first foods, and 2) the way settler colonialism governance restrains Indigenous relationships to land with necropolitical effects on both people and landscapes.

It is noteworthy that within huckleberry meadows we find another environmental and political boundary where Indigenous food sovereignty comes into tension with the sustainable agriculture-focused alternative food movement. The Yakama and other Coast Salish actors express deep concern over how huckleberries are being harvested and managed by commercial users - who turn out to be businesses marketing the "addedvalue" of food products that are "local," "place-based," and "organic." It is another illustration of how the alternative food movement's agrarian imaginary advances food system "re-localization" as a kind of environmental goal that imagines white, agrarian settlement as its temporal horizon. In doing so, it replicates land practices and ideologies rooted in and that perpetuate Indigenous erasure.

For Tend, Gather, and Grow, group huckleberry picking is important as part of Indigenous survivance, thrivance, and ongoingness under and past settler colonialismnot merely in opposition to it. Certainly, Coast Salish food revitalizers in Tend, Gather, and Grow were certainly critical of capitalism and colonialism and its effects-linking the 
recent emergence of diabetes in their communities to these processes. Unlike many food justice and health disparities scholars, Indigenous food sovereignty actors here have homed in on the fact that diabetes and other chronic diseases being experienced cannot simply be described in terms of unequal access to healthy food. Specifically, diabetes is an embodiment and materialization of settler colonialism. Perhaps what is most strikingly different in Coast Salish food sovereignty practice compared with a wide spectrum of alternative food system work in North America—from sustainable agriculture to food justice — is that it is devoid of the assumption that settler colonialism and/or the settler colonial state are inevitable. Working with Salish people on food and environmental issues for 18 months in Washington State impressed on me how much the commonsense inevitability of settler futurity simply does not exist in certain Indigenous spaces. Part of the premise of Tend, Gather, and Grow was to be a part of ensuring that Coast Salish people will be able to navigate the land well generations into the future, beyond the obvious unsustainability of settler society for people and nonhumans.

\section{cabidac: Coastal Garry Oakscapes and Camas Prairies}

Next to the experience of "huckleberry camp," lesson-planning around camas in Tend, Gather, and Grow involved some of the most intensive and experiential work of our curriculum-making project. For our mid-May Tend, Gather, and Grow meeting, we met at Mima Mounds Natural Area Preserve as blueish-purple camas lilies began to appear in certain corners of South Puget Sound's lowland prairies. Gathering in the parking lot, we walked to the edge of the prairie where Elise asked us to sit together before strolling through the park. For those of us unfamiliar with it, she explained that 
this strange, undulant landscape spins a mystery. It is an expanse of grassy, evenlyspaced, six to eight foot hummocks (or mima mounds) encircled by an abrupt edge of Douglas firs. A number of theories circulate about how this topography came to be, but there is no widely held consensus other than that the mounds present an enduring enigma. That Salish stories describe how this meadow existed "before the flood" lends to theories that the mima mounds formed out of residual sediment from massive glacial melt waters (Storm 2004). Excavation reveals the mounds are constituted by gravel-outwash, with a significant top layer of anthropogenic soil—accumulated fine charcoal for repeated burns (Ugolini and Schlichte 1973). Researchers agree that this and other prairie and oak woodland savanna ecosystems formed approximately 10,000 years ago, and that the persistence of the prairies is attributable to Indigenous burning. We spent several hours here before caravanning to the Chehalis Reservation thirty miles southwest to dig camas.

Camas and Garry oak trees often lived together in Salish prairies maintained by Indigenous peoples, sometimes referred to as the "Garry oak ecosystem"—open, sunlight-receiving spaces apart from but amongst canopied conifer woods. Burnings kept conifer encroachment at bay, maintaining expanses where oaks, grasses, root vegetables, and other plants could flourish. The prairies were also a place visited by game — deer, elk, and sheep. Puget Sound prairies and their oak woodland edges provided a hub of highly variegated food, fiber, and medicinal sources. $35 \%$ of the inventoried plant species in Mima Mounds are edible, and 85\% have a documented ethnobotanical use (Storm 2004; Turner 1998; Turner and Kuhnlein 1983).

In a 1927 federal court case known as Duwamish et al. V. United States of America, in which the Northwest Federation of Indians sued for land returns and fishing 
rights implementation accorded to them in treaties, 92 year old Upper Chehalis elder, Mary Heck, testified to the importance of prairies as sites of plenty. Responding to the question were "the prairies the place where they got the most of their camas roots that they ate?" she answered, "they abounded with all kinds of roots they used for food," including three kinds of camas. She explained there "was a little kind and a big kind, and then there was a kind that was not used for food, but used rather for medicinal purposes" (Storm 2004).

For only a few weeks beginning in mid-May, camas lilies decorate Puget Sound prairies, blanketing them in periwinkle. This display not only signals that it is time to harvest camas roots, but marks off edible camas (Camassia quamash, cabidac in Lushootsheed) from "death camas," a nearly identical plant relative that grows among its edible kin, but is toxic to humans - distinguishable because its lilies are white. The edible portion of the plant is a "bulb" that sits just above the roots under the ground. It is similar in appearance to the edible bulb of a green onion, only more bulbous - ranging from $1 / 4$ " to 2" in diameter. Technically the camas "bulb" is a "corm"- -both are underground storage units, but corms are a modified part of the stem rather than comprised of layered scales. Nonetheless it is commonly referred to as a bulb. Camas bulbs are a high-energy food - they look like an onion but taste and feel like a starchy potato. They are complex carbohydrate rich, and specifically contain inulin, a type of fiber that has a balancing effect on blood sugar, functions as a "probiotic," and aids in the body's absorption of calcium, magnesium, and other minerals. Camas was important as a staple to inland and upriver Salish people, and was a trade item moving from the Puget Sound area to the 
eastern side of the Cascades (Storm 2004). Camas bulbs can be boiled, but are often slow cooked to bring out sweetness and flavor.

Camas covers the Mima Mounds from May to June, rendering the strange meadow even more spectacular. A few miles away, camas flourishes too on Glacial Heritage Preserve. Yet these now separate parks were once part of a contiguous 3,200acre prairie (Storm 2004). Now shrunken and fragmented into much smaller areas, even these preserved environments reflect that Northwest camas prairies and Garry oak ecosystems have nearly disappeared in the last 175 years. Disruption began in the mid$19^{\text {th }}$ century as settlers increasingly arrived to stake claims, clear the land for agriculture, and raise livestock (Baker 2018). The Newaukum Prairie, Fords Prairie, Jackson Prairie, and Boisfort Prairie were all converted into farmland by Euro-American settlers (ibid.). Settlers implemented fire restrictions that disrupted the long-established land-tending regimes that maintained the prairies. A steady introduction of invasive species (botanical colonizers like Scotch broom and Himalayan blackberry) along with a growing settler population, and subsequently urbanization compounded the process of prairie loss. Only a small fraction of Garry oak ecosystems has survived agricultural conversion and urbanization (ibid.). Extant prairies persist because of management practices performed by Indigenous knowledge keepers and others who either incorporate or simulate the effects of burning through cutting and pulling encroaching plants species.

\section{The Ongoing Harvest}

While $90 \%$ percent of camas prairies have disappeared in the last 200 years, there continue to be Coast Salish people across Puget Sound who return to prairies where 
camas emerges in May and June. Young tribal leaders are initiating projects and partnerships to revitalize camas harvesting, camas prairie tending, and knowledge about camas as an important native food, including several members of Tend, Gather and Grow belonging to the Squaxin Island Tribe, Yakama Nation, and Spokane Tribe.

While it was important to visit Mima Mounds, as a preserved site people are not permitted to perform camas digs there. Elise planned for us to spend the second half of the day in a field outside the home friends she had on the Chehalis Reservation. It was about a 40-minute drive from the mounds to this site. The family had left us enough digging sticks for each of us. The digging sticks we used were metal—about $2 \frac{1}{2}$ feet long with two handles protruding outward at the top. Behind the house was an open field where the grass as taller-about $1 \frac{1}{2}$ feet high. Dozens of Douglas Firs stood out against the periphery of this meadow. There was one patch of grass-approximately 200 square feet—adorned with clusters of purple flowers. Mariana (Yakama), Joyce, and Charlie already knew how dig camas, but Elise provided a demonstration to the group nonetheless as we sat in the grass. You choose one among a grouping of camas plants, hold the stem, and follow it down to grasp where it is rooted in the soil. Making sure not damage any of the surrounding roots, you begin to begin to dig around the plant several inches out, with the aim of pulling it out with its roots in tact. Once you've penetrated the ground, you can use your hand to try to feel where the roots are, lifting it up without severing the roots or bulbs below. Pulling up my first camas, I wiped away the crumbling dirt from the bulb to see what it looked like. It had skin like the interior layers of a white onion and was approximately three quarters of an inch in diameter. I laid the long plant in its entirety—its purple flowers, stem, bulb, and wiry roots beside myself so I could dig up 
the next one. As we worked, Elise reminded us that digging and harvesting the camas this way aerates the soil, helping to increase next year's yield.

We dug together for a little under an hour. By the end I had pulled 12 perfect bulbs from the ground. Deciding it was time to depart soon to get home to our families, Elise showed us how to remove and store the bulbs. You first pinch off the stem at the point it enters the bulb. You can leave the rest of the plant biomass in field to decompose. Placing your bulbs in a bag or container, you then peel of the brown outer skin, revealing the onion-like white bulb. These can be rinsed and cooked to eat right away or to store, or they can be rinsed and frozen.

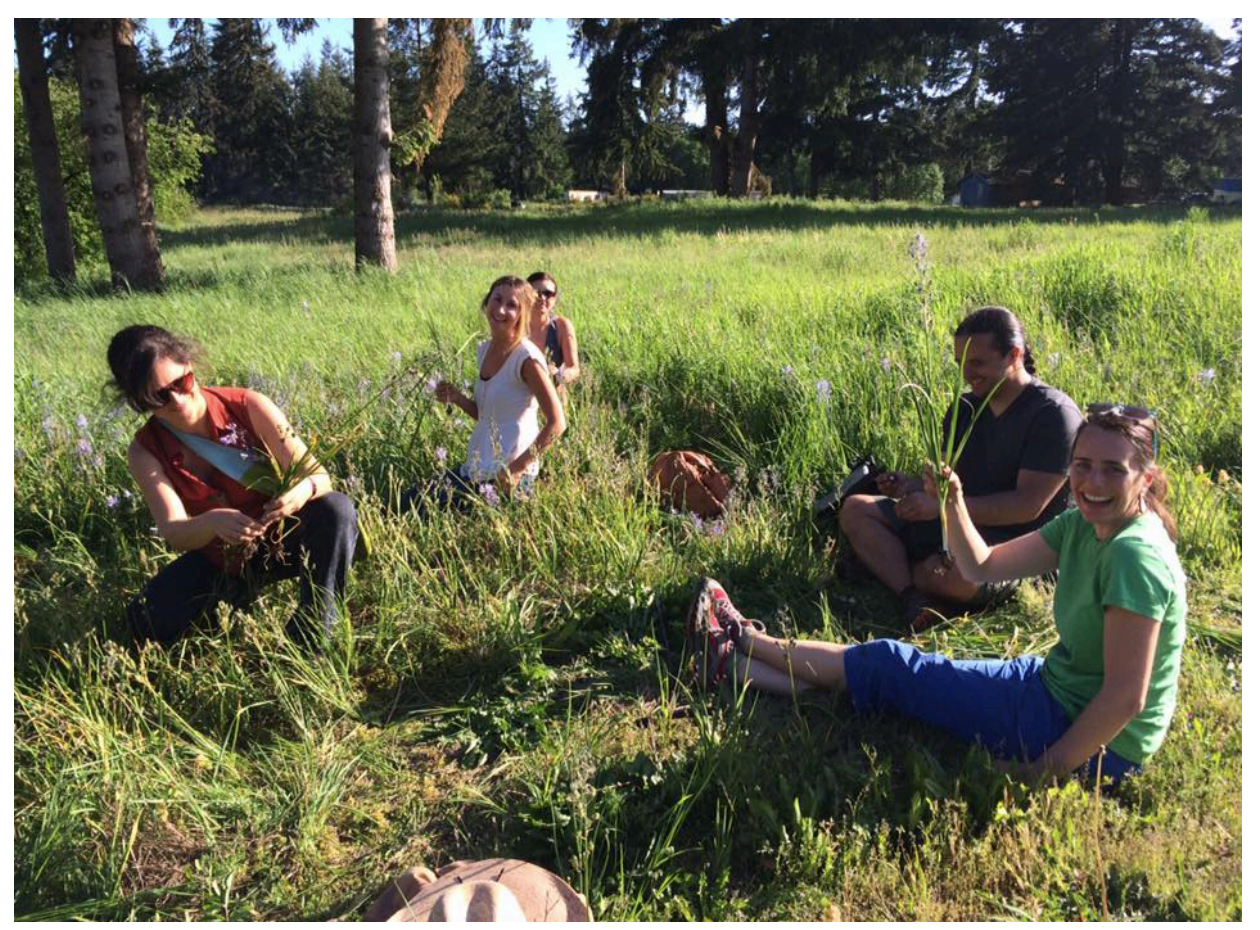

Fig. 5.3 Tend, Gather, and Grow team members digging camas on the Chehalis Reservation. Note the tree line against the open meadow. (May 28, 2016)

Tend, Gather, and Grow developed lessons around camas as part of the curriculum with the aim of helping to revitalize and ensure a future for this deep time 
human-plant relationship, its ecologies, and its role in figuring Indigenous ongoingness. Just as our work emerged as part of a growing network of Coast Salish food revitalization and tribal food sovereignty organizing in Puget Sound, our work linked up with projects that further expanded involvement in Indigenous led camas prairie revitalization.

Two of Tend, Gather, and Grow's core team members, Aleta Proste (Squaxin Island) and Elizabeth Campbell (Spokane), established the Squaxin Island tribal garden while working with TGG. The garden would be a space to produce traditional and ancestral foods and medicines, and to help distribute healthy food to the community. They built on Tend, Gather, and Grow's camas lessons and their own expertise to facilitate camas digs for the Squaxin Island Tribe through the tribal garden's programming. In May, 2017, Aleta and Elizabeth organized an outing into South Puget Sound prairies in which a group of Squaxin Island tribal members harvested camas and learned how to do a traditional pit roast to cook the bulbs and prepare them for monthslong storage. Pit roasting make camas available as a food source in winter. It takes one two days to complete, but brings out the sweetness and flavor of the bulbs. Elizabeth provided the demonstration. The Northwest Treaty Tribes, formerly the Northwest Indian Fishing Commission - an intertribal organization that supports western Washington tribes exercise of their treaty rights—-publicized their work.

A year after Tend, Gather and Grow's field trip to Mima Mounds, several team members began a new project and collaboration between educators, ecologists, conservationists, and knowledge holders coming from various tribal, non-profit, government, and academic bodies and institutions in Washington State. Together this team received institutional support and funding from the University of Washington to 
initiate the "Camas Prairie cultural ecosystem incubator." Elise, Joyce, and Aleta were foundational in organizing this collaborative and groundbreaking project.

The incubator articulates the need to revitalize camas prairies as "cultural ecosystems" (see Chapter 2 to see how this builds on the work of Tend, Gather, and Grow) that maintain important "cultural foods in Coast Salish territory and $[\ldots]$ continues to play a key ecological role, providing early season nectar for two federally endangered butterflies and countless other pollinators" (University of Washington Center for Creative Conservation 2017). The project would seek to contribute to the revitalization of "cultural practices by educating younger generations and engaging both tribal and non-tribal members in conservation and restoration of these critical habitats," which have become nearly lost due to colonization, agriculture, and urbanization (ibid). In articulating their mission and objectives the collaborators stated

While there are a number of prairie conservation and management groups focused on the care of these increasingly rare ecosystems, to our knowledge, we are the only group that explicitly focuses on Pacific Northwest prairies as cultural ecosystems. The recognition of camas prairies as cultural ecosystems informs our goals and shapes our broader commitments to prioritize tribal needs and interests in the development of the research and teaching program.

The team expressed that this is a short- and long-term vision and set of goals defined through the process of communication.

During their first meetings, the incubator team defined their collective identity in terms of "'community of practice' that learns from the plants, prairies, and one another" (University of Washington Center for Creative Conservation 2017). Together they authored the following statement 
Drawing on western and Indigenous ways of knowing, this project will foster the health of Salish Sea prairies and the well-being of people connected to them, through collaborative partnerships based in trust, reciprocity and respect (ibid.).

As a group they discussed challenges facing this collaboration. For one, settler science and land-management agencies privilege "certain standards of proof and ways of knowing non-human nature, implicit (and explicit) ideologies that see humans as separate from non-human nature" (ibid). Secondly, "building trust between tribal communities, scientists, land managers and agencies" would require effort, given historical relationships and asymmetrical power between these kinds of actors within ongoing structures of slow violence.

\section{Indigenous Food Sovereignty, Co-Management, and the Trouble with}

\section{The Commons}

This aspect of my research allowed me to examine the relationship between Indigenous food sovereignty and public lands in Washington State in order to make several conceptual interventions into noted sticking points, contradictions, and puzzles within and between 1) North American critical food studies and Indigenous sovereignty and settler colonialism, and 2) Indigenous food sovereignty in North America and the global/transnational food sovereignty movement.

In 2017, ACME: An International Journal for Critical Geographers released a special issue seeking to link critical scholarship on urban agriculture in North America to "processes of neoliberalization in European cities and efforts to resist these processes" (Darly and McClintock 2017). In providing a survey of the critical literature North 
American urban agriculture (UA) in geography, it includes settler colonialism among a set of structurally violent processes of which UA stands in a relation of integument (ibid). That the editors reference only one paper that puts forth a settler colonial analysis of urban agriculture in North America—Sara Safransky's “Greening the urban frontier: Race, property, and resettlement in Detroit" (2014) —reflects that the connection between settler colonial studies and critical food systems literature remains sparse. The article provides a fascinating analysis of how neoliberal green infrastructure projects replicate modes of "green dispossession" through the settler colonial logics of human erasure via wilderness tropes.

However, in the article, Safransky treats Native American dispossession primarily as a historical precedent and parallel to more processes racialized displacement affecting primarily African Americans in Detroit. She does not name or refer to the Ottowa, Anishinaabe, Ojibwe, Potawatomi or any other living Indigenous peoples presently inhabiting Detroit and/or for whom the city comprises still contested Indigenous home/lands. While engaging settler colonialism as an ongoing structure that continues to effect and enroll people and the land in violent and ecocidal ways, it misses Indigenous critiques of settler colonialism that seek to center indigenous decolonization as a key "process that restores life and allows settler, arrivant, and native to apprehend and grieve together the violences of U.S. empire" (Byrd 2011). Geographer Clint Carroll has echoed other scholars in identifying how settler colonial studies "risks de-centering Indigenous peoples['] own articulations of Indigenous-settler relations, their governance, legal, and diplomatic orders, and the transformative visions entailed within Indigenous political 
thought" (Carroll 2017). Perhaps it is by way of seemingly instantiating this risk that Safransky concludes her article by arguing in favor of classifying de facto public land as a "commons."

Safransky's alignment of the commons with decolonization is not unique in critical scholarship across the social sciences. One way to bring de/colonization into conversation with the Marxian thesis of "accumulation by dispossession" is to define colonization as "the theft of the commons" and decolonization as "the gaining of a global commons" (Sharma and Wright 2008, 133). Indigenous critiques of North American settler colonialism have engaged with U.S. preserved wilderness areas and public lands, among other things, to critique the notion that commons is decolonizing, per se. Indeed, settler structure depends on transforming land into property, and moving land outside of property regimes and logics constitutes the necessary work of decolonization. But not only have, in certain instances, the concepts of public land and land as Commons worked against Indigenous sovereignty, but in some ways these concepts have always functioned as property's counterpart, not its counter.

Like Safransky, Jodi A. Byrd (Chickasaw Nation of Oklahoma) wants to "contend with how the vexed histories of slavery and conquest continue to inflect our understandings of the past and present" (Byrd 2011). Yet while Safransky goes on to suggest ways this might happen on "public land" in places like Detroit, the key for Byrd is how such a reckoning might "help us to imagine decolonial futures for all those who find themselves here on our [Indigenous] lands" (2016 emphasis mine). This is a critical distinction because it instantiates how prevailing conceptualizations of race and racialization within US critical scholarship "depend on an historical aphasia of the 
conquest of indigenous people" (2011). Byrd fully acknowledges such scholars to be sympathetic to the experience and violence of Indigenous dispossession in the U.S., but observes they then still relegate these ostensibly originary violent acts to a disappearing horizon of the colonial past, increasingly "eclipsed by the waxing importance of racial hierarchy [rather than geopolitical claims to land and sovereignty] in the workings of the US empire" (Fawaz 2012).

K. Wayne Yang puts forth a critique of the Occupy Movement to argue that "[e]ven the progressive concept of land as Commons to be occupied, collectively shared and stewarded, may require the negation of Indigenous sovereignty" $(2014,121)$. Specifically, Yang examined Occupy Oakland, which began in 2011 linking up with the larger set of movements spurred by Occupy Wall Street. Describing how "various queer, people of color and Indigenous groups participated in or sympathized with Occupy and recognized its importance as a meeting space, a node, for struggle," he notes that, "many of these groups had serious points of difference, most notably in the problematic name, 'Occupy"' (2012). In October of that year, "a group of Indigenous and non-Native intellectuals/activists introduced 'The Memorandum of Solidarity with Indigenous Peoples' at the General Assembly of Occupy Oakland" (ibid). It read

WHEREAS, those participating in 'Occupy Oakland' acknowledge that Oakland is already occupied land; Oakland being the historical territory of the Chochenyo Ohlone people; and ...

RESOLVED, that those participating in 'Occupy Oakland' seek the genuine and respectful involvement of indigenous peoples in the rebuilding of a new society on their ancestral lands; and As a signal to the national 'Occupy Wall Street' movement and the indigenous peoples here and there who 
have felt excluded by the colonialist language of occupation used to name this movement, it shall be declared that 'Occupy Oakland' aspires to 'Decolonize Oakland' - to 'Decolonize Wall Street' - with the guidance and participation of indigenous peoples;

The memorandum points a different "modality of organizing" and centers the political leadership of "Indigenous peoples in any decolonial effort in North America" (ibid).

Controversy emerged within the Occupy Oakland group before the memorandum was ultimately passed, turning on expressed anxieties about decolonization. On a public blog, one of the signers explained

what they were asking is whether or not we were asking them, as non- indigenous people, the impossible? Would their solidarity with us require them to give up their lands, their resources, their ways of life, so that we - who numbered so few, after all - could have more? Could have it all?

As Yang puts it, "this is the rub about decolonization: it forces people to confront their complicity in settler colonialism and the ongoing violence of empire" (ibid). The memorandum "immediately unsettled the utopian vision of wealth redistribution and collectively owned Commons" (ibid). This articulation of and centering of decolonization unsettled the presumption in many social justice projects that land constitutes the blankslate background upon which to create something radically new.

In her work on critical pedagogy, Sandy Grande sides with Marxian critiques of a (de-radicalized) politics of representation within education and affirms the need to foreground historical-materialist analysis that " provides critical pedagogy with a theory of the material basis of social life rooted in historical relations' and assigns primacy to uncovering the structures of class conflict" $(2004,25)$. She does so in agreement with 
those eschewing the universalism of Marxist revolutionary theory, asserting that it "must be flexible enough to reinvent itself," useful as "a weapon of interpretation" $(2004,25)$. She sees the understanding of culture as conditioned by materialist forces and schooling as a site of struggle to offer "great potential for indigenous peoples working toward pedagogies for self-determination" $(2004,26)$. Yet she also wants to put forth the question "do Marxist pedagogies of emancipation sustain a geopolitical landscape any more receptive to the notion of indigenous sovereignty than capitalist pedagogies?" $(2004,27)$. The endgame here is human liberation, "a profoundly anthropocentric notion, rooted in a humanist tradition that presumes the superiority of human beings over the rest of nature" (ibid).

Grande asserts that 'both Marxists and capitalists view land and natural resources as commodities to be exploited, in the first instance, by capitalists for personal gain, and in the second by Marxists for the good of all' $(2004,27)$. Looking at the relationship between Indigenous food sovereignty and Washington State public lands further illuminates this under-examined relationship, and the implications for revealing alternative food politics and practices relationship to the settler colonial present, settler futurity, and/or Indigenous futures.

We can see that Mishuana Goeman's reminder that "[Indigenous people within the U.S. and Canada] still speak of the sacredness of places now claimed by the parks services" (Goeman 2008, 32) rings true for Salishan people living in Washington State. The recent moves forward on the part of Coast Salish people establishing working partnerships with land managers, scientists, and community members newly open to exploring ways to reintroduce Indigenous burning and other land management practices 
on these lands are, while modest, remarkable. Particularly because this delicate, complex, collaborative work centers around food and Indigenous food sovereignty, it opens a window into questions about alternative food practice/politics, decolonization, and settler land use regimes and imaginaries - including the transformation of land into both property and preserved wilderness/public land.

It is worth noting here that the social scientific literature on "parks and people" includes a sub-area of mostly environmental historical scholarship that reinterprets "the history of national parks and protected areas in the United States, focusing on the simultaneous containment of Native Americans onto reservations and the creation of national parks in the American West at the end of the nineteenth century" (West, Igoe, and Brockington 2006; cf. Burnham 2000; Catton 1997; Jacoby 2001; Spence 1999). Yet while the broader literature acknowledges that the American preserved wilderness parks "served as models for preservationist efforts and native dispossession all over the world," the ways in which this way of imagining and reshaping the land, shaping and reshaping social worlds in the process, stems from settler colonial imperatives of elimination remains under-researched or conceptualized.

In challenging the notion of the commons, ethnic studies scholar Lindsey Schneider points out that the "'public' land of national parks, national forests, and other 'wilderness' areas $[\ldots]$ constitute the closest thing to a commons that exists in the United States" $(2016,179)$. She argues the notion of the commons itself can hide the way land/resource conservation is linked to resource/land exploitation. She argues that U.S. settler colonialism's "separation of land into spaces of [...] private allotments and wilderness, is based entirely on whether or not humans (and in particular, men) have 
interacted with it" $(2016,179)$. This "androcentric" separation of space, "not only assumes a false chronology of human interaction with land in the West (i.e., that it began with Lewis and Clark), but also elides the effects and implications of settler colonialism for nonhuman species and natural entities, such as rivers, lakes, rocks and other minerals, air and weather, and the soil" (ibid). Both exploitation and conservation as systems of land use - whether resources, animals, plants, stem from the distinctly settler notion that "humans play the pivotal role in determining whether land will be as close to 'pristine' as possible or as efficiently utilized as possible, when in fact neither is a feasible reality" (ibid). She contrasts how settlers' conservation ethic prioritizes, for example, the "absolute preservation of an animal's inherent right to exist as a species," with Columbia River Basin Tribes' ethic as about "the need to respect the integrity of a species" (2016, 195).

One of the main differences therein lies with settler norms of relating to land generically. The overly generic conception land, she argues, underpins the notion of the commons. Schneider submits that "the commons disavows its own roots in the same androcentric ideologies that accompanied and enabled settler colonialism to operate, and that it only makes sense as the solution to an overly generic account of settler colonialism that denies the differences between its geographical variants" (ibid). Schneider fascinatingly points that the treaties signed between Columbia Basin peoples and the U.S. government in the 1850 's "are worded as if they were actually supposed to implement the commons" (ibid). Like the Treaty of Point Elliot and Medicine Creek Treaty signed with Salishan peoples on the west side of the Cascade, which have served as the centerpieces of contested law in fishing rights struggles, they state 
The right of taking fish at usual and accustomed grounds and stations is further secured to said Indians in common with all citizens of the Territory, and of erecting temporary houses for the purposes of curing, together with the privilege of hunting and gathering roots and berries on open and unclaimed lands (Treaty of Point Elliott 1855, emphasis mine).

The language and visions of the commons and public lands have since the time of official U.S. settler occupation worked to devastate the reciprocal relationships between Native peoples and their lands.

Coast Salish people do not seek to enact "abstract generalities or management principles," but rather to continue performing longstanding, evolving "relationships based on respect for and responsibility to the land" (ibid). It is a way of apprehending land that not only exceeds a conservation-exploitation binary, but that demands understandings of the specificity and long co-species histories of place/s.

Certainly, the commons is not an antithetical notion or politics relative to Indigenous food sovereignty, but one rather in need of intervention and revision if it is going to align/ally with projects of Indigenous sovereignty, decolonization, and Indigenous futurity in settler-state contexts.

\section{Decolonizing Lands/cape}

What the work being done on public lands in partnership with tribes, alongside the work tribal food revitalizers have been doing on private and tribal lands, emphasizes that it is not by virtue of being "public land" alone that this food work is decolonizing. Certainly, it is interesting that it is in the parks, these spaces of displacement and 
dispossession, that modest but important collaborations are taking place, which I would argue are in many ways meaningfully decolonizing.

In asserting this, I am deferring to discussions of de/colonization put forth by Indigenous scholars across Turtle Island. In this chapter specifically, I lean on the way Eve Tuck and Jodi A. Byrd discuss decolonization. Tuck intervenes into the vogue (over)use of decolonization in North American academia and activism to argue that "decolonization is not a metaphor" (2012). While there is import to the discussion of "decolonizing thought," decolonization ought never to be abstracted from specific lands and the specific ways colonialism has circumscribed the ways humans relate to them. As we saw with the Oakland Occupiers, when we define decolonization as necessarily entailing accountability to the socio(ecological) orders prior to and that have persisted under settler colonial occupation, it foregrounds what are for many far more unsettling questions about cohabitation in specific places.

For Angie Morill and Eve Tuck, one way of beginning that conversation is to define the opposite of dispossession not as possession, but unforgetting and mattering (2016). This means that if remembering fails to be part of communing or worlding anew, it remains colonialist. Byrd also invokes the notions of matter as well as memory in contrast to forgetting. She affirms,

colonization matters. For indigenous peoples, place, land, sovereignty, and memory matter. In a world growing increasingly enamored with faster, flatter, smooth, where positionality doesn't matter so much as how it is that we travel there, indigeneity matters (2011, xiii). 
Through her work, Byrd makes the transformative argument that "indigenous peoples must be central to any theorizations of the conditions of postcoloniality, empire, and death-dealing regimes that arise out of indigenous lands" (2011, xiv).

With this premise established, Tuck articulates that her "commitments are to what might be called an Indigenous futurity, which does not foreclose the inhabitation of Indigenous land by non-Indigenous peoples, but does foreclose settler colonialism and settler epistemologies" (Tuck 2013). "Indigenous futurity does not require the erasure of now-settlers in the ways the settler futurity requires of Indigenous peoples" (ibid). Yet grappling with "enforced settler cohabitations" on Indigenous lands will require "the best of indigenous government traditions to imagine, innovate, and restructure kinship sovereignties in order to repair the violent breaches of family, history, and tradition that forced people into indigenous lands" $(2011,207)$.

In the time I spent working in various capacities with or in proximity to Valerie Segrest, it was very clear that establishing and advancing relations of co-management with land and resource managers in Puget Sound constituted one of the most important means of establishing food sovereignty right now and in securing more robust food sovereignties in the future. As we have seen, Valerie is polite and generous but clear both in her criticism of public land managers for not doing enough to work with tribes, as well as commending them for what is being done and what has changed in recent years.

The Umatilla outlined a "first foods" plan that articulates the approach of Coast Salish traditional food revitalizers and food sovereignty organizers in Tend, Gather, and Grow. For them, food sovereignty and restoring first foods entails "people's reciprocal responsibility to respectfully use and take care of the foods [...] even though the means to 
pursue, acquire, process, and prepare First Foods have changed dramatically following Euro-American settlement" (Jones 2008, 1-2). While state recognitions of treaty rights are certainly not the ultimate goal of Indigenous food sovereignty in Salish Country, holding and expanding spaces in the present is part of the critical work creating Indigenous futures now.

These instances of collaboration that are being forged around Coast Salish people's articulations of and everyday practices of tribal food sovereignty offer glimpses into a model and ethic of solidarity beyond multicultural inclusion or a more radical anticapitalist politics. In as much as anti-capitalist and other anti-oppression scholars and activists have attempted to simultaneously incorporate anti-colonialism, particularly in the domain of food politics, what decolonization means in settler contexts has been glossed over in ways that leave glaring inconsistencies between the goals and futures of Indigenous sovereignty and other emancipatory projects. 


\section{CHAPTER 6: Conclusion}

This dissertation examines Indigenous and non-Indigenous food actors in Puget Sound, their relationships to each other, the land, the U.S. settler-state and its lines of flight. Specifically, it is a study of the practices and (geo)politics of Indigenous food sovereignty in South Puget Sound, and the environmental and political spaces in which it meets and competes with settler food projects that also seek to reshape society and the land through food production, distribution, and consumption under the banners of social justice, food security, and environmental sustainability.

The study is based on qualitative research conducted in South Puget Sound over a period of 18 months, where I worked with two related Coast Salish food sovereignty projects that brought Indigenous and settler food actors into transformative collaborations. One of these projects focused on the revitalization of Coast Salish plant landscapes, knowledge, pedagogies, and systems of reciprocity. The other was a campaign to counter the introduction of genetically engineered salmon into U.S. food markets and coastal production facilities across the Western Hemisphere, situating this development within longstanding salmon-centered social and political struggles in Coast Salish territories in the context of Indigenous/settler-state relations.

Through this research, I identified patterns in how Coast Salish food actors push back against the ways utopian food projects in settler society, particularly as they are rooted in Lockean agrarian logics, are rooted in the fiction of terra nullius. By deeply engaging with the histories, politics, and futurisms of Coast Salish refusal in relation to food and examining settler alternative food praxis through the lens settler colonialism, I was able to identify a set of mechanisms or technologies that have and continue to make 
utopic settler food politics and projects, both hegemonic and counter-cultural, an ouroboros of settler coloniality - and to point to how people here are working their way toward alternative models of solidarity that might better confront and subvert those deeply underlying dynamics.

Taken together, the dissertation chapters make the argument that US settler colonialism has always been and continues to be constituted by utopic agrarian philosophies and projects promising revolutionary equality, liberation, and righteous ways of relating to land, while operationalizing these ideals in ways that work to eradicate Indigenous life and render illegible Indigenous sovereignty. By illustrating that the "agrarian imaginary" (Guthman 2004) is one of the primary mechanisms through which settler colonialism "destroys to replace" (Wolfe 1999), I point to both the problems and possibilities inherent in settler-Indigenous solidarity building around systems of food production in the Northwest and across Turtle Island. To do so, I abandon a comparative approach in favor of a relational one-investigating the historical and ongoing relationships between settlers' food-centered social movements and Indigenous sovereignty in Western Washington State. I argue that because agrarianism, property, the Human, the 'elimination of the Native' (Wolfe 1991), and US modernity are coconstituting, an alternative politics of solidarity and livability would hold now-settlers accountable to coming to know "the American landscape"-geopolitically and epistemically—not as a backdrop for liberal diversity, as an anti-capitalist commons, or as a becoming, but as so many still Indigenous lands.

In Chapter 2, I explored the historical role of agriculture in colonial resettlement in Washington State. I traced the imbrications between Anglophone political philosophies 
and practices of agriculture, and how they are constitutive of U.S. settler colonialism, which engenders particular opportunities and desires for relating to, belonging to, and owning land on the part of settlers. I emphasize how this relates to Coast Salish humanland relationships that exist largely through systems of food and eating. I highlight that Coast Salish peoples prioritized these relations during treaty negotiations and have refused to cease living according to modes of relationality. That this occurs in large part by continuing to produce food and struggle for their ability to do so stands to be made visible as exposition of both the violences settler colonial present and its fictions. I made the case for opening more robust conversations about the linkages between agriculture, territorial claim, and Indigenous dispossession in North America in the food studies literature. I did this pointing to how what Julie Guthman calls "the agrarian imaginary" remains hegemonic across the gamut of alternative food system work in the U.S. However, I went on to trouble Guthman's conceptualization of 'agrarian imaginary' for participating in the way Indigenous dispossession is situated in a tragic but settled past, lending to the flattening of Indigeneity into another racialized minority.

Chapter 3 draws from my participant-observation experience with Tend, Gather, and Grow to examine the dynamics between Coast Salish food sovereignty actors and a celebrated food justice/urban agriculture organization in Olympia, Washington. I put Jodi A. Byrd's concept of "cacophony" alongside scholarship on urban Indigenous land pedagogies to limn the sticking points of this collaboration, and what they reveal about deep-seated tensions and incommensurable futurities between alternative food movements in settler society and Indigenous (food) sovereignty that are largely unacknowledged and not well understood. 
In Chapter 4, I examined a campaign established by the Muckleshoot Food Sovereignty Project and Community Alliance for Global Justice to put forth a settler colonial analysis of the politics around AquAdvantage Salmon, the first genetically engineered animal for human consumption, and its attendant transoceanic infrastructures, focusing on its imbrications with Coast Salish people and homelands. In this chapter I linked the novelties introduced through the production of a transgenic global foodcommodity salmon have expanded GMO food controversies and legal battles with an enduring history of salmon-centered sociopolitical struggles in the context of IndigenousU.S. settler state relations in Washington State. I took this point of articulation as an opportunity to re-conceptualize the intersection of Native fishing and water rights struggles, salmon depletion, and Washington State's position within shifting regimes of capitalist accumulation - from resource extraction in the name of nation-building to nature privatization schemes. To do this, I draw from and complicate literatures conceptualizing the ways more-than-human landscapes, technology, and capitalism meet by focusing on the "politics of refusal" in Coast Salish territories as it is bound up with deep time human-salmon relationships.

Finally, in Chapter 6 I set out to illustrate how efforts to revitalize huckleberry meadows and camas prairies as Coast Salish fire ecologies reveal extraction and conservation/exploitation and commoning to be more isomorphic than we might imagine. I put Indigenous critiques of settler colonialism into conversation with critical food studies scholarship in a way that allows me to make the argument that while much of the critical food studies literature, along with a broader critical theory matrix, treats them as such, neither anti-capitalism nor Deleuzian approaches to 'worlding anew' are 
synonymous with decolonization. By examining recent work Coast Salish food revitalizers are doing and the partnerships they forging — largely through their articulations of tribal food sovereignty — in this chapter I am able to illustrate how these dynamics model a politics and ethics of solidarity beyond prevailing emancipatory concepts in North American social science and activism within and beyond alternative food work.

Taken together, these chapters indicate that the food utopias imagined and enacted by settler actors invested in Northwest food politics, even those considered to be progressive and radical, have not grappled with their structural positionings within settler colonial governing technologies. Specifically, it suggests this is so in as much as particular kinds of agrarian utopian logics are trafficked as a set of unexamined priors that have long informed how settlers have attached notions of equality, democracy, and 'the good' to Indigenous lands fictionalized, institutionalized, and shaped through law as the American landscape. These priors are traceable to Anglophone philosophers who helped make the project of the US settler state possible by constructing notions of humanness against Indigenous human-land relationships, enabling a legal order and definition of sovereignty permitting territorial acquisitions of long inhabited and governed lands - along with its requisite forms of violence. Utopic agrarianism articulates for colonizing settlers how Nature is enrolled in the governing logic of erasure - rendering the land as empty (terra nullius), discoverable, a blank slate to enact liberal notions of progress, and available for possession by civilizers. While I do not argue that progressive and radical food actors explicitly seek to continue to dispossess Indigenous peoples of their lands and territories, indeed even as they express desires to 
"include" Indigenous people as beneficiaries of their politics, they rehearse as a matter of course ideas about and relationships with nature that work to erase Indigenous humanland relationships, and that naturalize settler futurity.

\section{Contributions to Research Areas and Theoretical Literatures}

This study is unique in attending to how settler colonial theory, Indigenous critical theory, and Indigenous politics in North America enrich and complicate the literatures provincializing modernity's Nature-Culture divide, as well as a largely Marxian and antiracist critical food studies literature. It not only contributes to engaging settler colonialism as "project of redefinition" for the study of U.S politics and society, but brings that project into the ambit of North American critical food studies scholarship. It makes contributions to the food sovereignty literature, US critical food studies scholarship, US anthropology, and the anthropology Native North America, while contributing to theoretical literatures grappling with ontological pluralism, capitalist modernity, liberation politics, and the Anthropocene.

Since the 1990's, local and sustainable food system change has been hailed as a forefront of the "new environmentalism" across a range of scholarly literatures and in popular culture (Friedmann 1993). The critical food studies scholarship has in recent years complicated this picture, focusing on how the cultural politics of US alternative food activism excludes non-whites through unacknowledged spatial practices, cultural codings, and economic prohibitions (Alkon and Agyeman 2012; Guthman 2007; Slocum 2011), and ultimately takes form as a rolling out of neoliberal governance (West 2013; 
Besky 2014). This research has focused on unsuccessful efforts to "bring good food" into African American neighborhoods under the banner of food justice (Alkon 2007;

Guthman 2007), the whiteness of alternative foodspaces and practices, such as farmer's markets and community supported agriculture (CSAs) (Allen 2004; Slocum 2007; 2011), and the in/effects on exploited producers of organic and ethical labeling schemes in global food commodity chains (West 2013; Besky 2014).

Each of the lines of critique, however, have implicitly naturalized settler futurity, effectively disavowing ongoing Indigenous dispossession in ways that are typical of the critical theory matrix, to use Jody Byrd's words (see 2011). Indigenous peoples living within the US tend to be invoked either as a historical precedent and parallel to contemporary practices of racialized abjection and dislocation, or are enrolled as another minority lacking a status of equality and inclusion promised by liberal US democracy. By engaging with Indigenous critiques of settler colonialism and the mechanisms through which settler futurity is naturalized, this project interjects in far-reaching ways into the emancipatory and environmental politics of food-centered activism. It focuses on how Indigenous food politics and ontologies expose the deeply naturalized condition of the settler colonial present, and how this distinct colonial formation fundamentally shapes social and human-land relationships on Coast Salish lands and beyond.

In doing so, I also reframe and rethink how Native food and environmental resource politics in Washington State have been examined. Whereas Native fishing rights, Coast Salish plant cultivation, and what counts as an alternative food politics in the Northwest have been approached as separate phenomena and taken up across a set of relatively distinct literatures, I attend to how each of these spheres of activity are related 
to Indigenous sovereignty, Indigenous futurities, and decolonization across what is now the US. My research acknowledges, for one, how fishing and plant cultivation as domains of practice and social and socioecological struggle are integral pieces of Coast Salish life, and as part of what is increasingly being called Indigenous food sovereignty. Their separation into separate literatures obscures the significance of ongoing practices of Indigenous food production under conditions of settler colonial governmentality that has for over a century sought to eliminate these relationships to land. Indigenous food sovereignty for Coast Salish peoples refers to an epistemic relationship to the land, including changing and altered environments, and at its most basic level simply constitutes a refusal to cease being Coast Salish. These dynamics and politics cannot be robustly conceptualized through paradigms of racial justice or critiques of capitalist modernity alone. Rather, scholars and food actors must begin to attend how an ongoing colonial Indigenous-State relationship that turns on territorial acquisition in perpetuity, along with the role of (desiring) settlers as part of the structure, shape how US Empire maintains a national and global political economy organized around expropriation.

\section{Future Research Implications}

This research examines food and settler de/coloniality in Coast Salish territories in what in now Western Washington. Yet it also argues that settler colonization involves unique dynamics on always specific, un-generalizable, not-fungible lands constituted by their own socioecological histories. In order to widen studies of how Indigenous food sovereignty within settler states articulates with a global food sovereignty movement as 
well as local and national movements for more just, sustainable food systems, there is a need for this kind of engagement with Indigenous food actors across Turtle Island working in relation to their own treaties and geo/political relationships with US and Canadian settler states. In what ways do food movements in settler society in Los Angeles, Chicago, or in the Southwest, for example, invisiblize or obscure efforts to decolonize those places and/or to hold the state accountable to its treaty obligations regarding food practices? What are the Indigenous socio-legal orders there to which current inhabitants of those lands find ways to engage and become more accountable? What are the barriers to Indigenous food sovereignty is specific places - how do those barriers challenge land and resource use regimes, whether public land, green development schemes, or extractive industry?

A broader and more theoretical research question would involve a shift in anthropology's focus on ontological pluralism and Indigenous ontologies toward a more sustained engagement with Indigenous forms of sovereignty that precede and diverge from the Hobbesian sovereign state, and their potential role in thinking through future forms of governance as the planet undergoes accelerated Climate Change. In Climate Leviathan, Geoff Mann and Joel Wainwright raise the question of what political scenarios will emerge as Climate Change becomes categorized as a state of emergency. They put forward four likely formations of power: the emergence of a global sovereign (Climate Leviathan), the reassertion of autarchic state sovereignties tied to a capitalist mode of production (Climate Behemoth), anti-capitalist authoritarian state socialisms (Climate Mao), or "Climate X"-an indeterminate alternative rooted in justice struggles rejecting both capitalism and authoritarianism. It is in conceiving and shaping this last 
possibility that new engagements with Indigenous thinkers, Indigenous peoples, and Indigenous modes of sovereignty would be critical. Indigenous sovereignties, for example, do not police borders with violence, but nurture responsible and affective relationships to lands. 


\section{List of References}

Alkon, Alison and Teresa Marie Mares. "Food sovereignty in US food movements: radical visions and neoliberal constraints" Agriculture and Human Valued 29 No. 3; (2012) p347-p359.

Alkon, Alison Hope and Agyeman Julian. Cultivating Food Justice: Race, Class, and Sustainability. Cambridge: MIT Press, 2011.

American Friends Service Committee. Uncommon Controversy: Fishing Rights of the Muckleshoot, Puyallup, and Nisqually Indians. Seattle: University of Washington, 1970.

Anderson, M. Kat. Tending the Wilderness: Native American Knowledge and the Management of California's Natural Resources. Berkeley: University of California Press, 2005.

ATNI, Affiliated Tribes of Northwest Indians RESOLUTION \#14 - 08 "Opposing the Introduction of Genetically Engineered Salmon.” 2014.

AquaBounty Technologies. "Report Prepared for the FDA Veterinary Medicine Advisory Committee," 2010.

http://www.fda.gov/downloads/AdvisoryCommittees/CommitteesMeeting Materials/VeterinaryMedicineAdvisoryCommittee/UCM224760.pdf.

Arnett, Joseph and Rex Crawford. "The Status of Huckleberries in Washington State" Natural Heritage Report 2007. Washington State Department of Natural Resources. November 30, 2007.

Avalos, Marial and John Winslade. "Education as a "line of flight"' Explorations: An EJournal of Narrative Practice no. 1 (2010): 70-77.

Bang, Megan, Lawrence Curley, Adam Kessel, Ananda Marin, Eli S. Suzokovich, George Strack. "Muskrat theories, tobacco in the streets, and living Chicago and Indigenous Land" Environmental Education Research 20 no. 1 (2014): 37-55.

Belmessous, Saliha (ed). Native claims: Indigenous law against empire, 1500- 1920. New York: Oxford University Press, 2012.

Besky, Sarah. The Darjeeling distinction: Labor and justice on fair-trade tea plantations in India. Berkeley: University of California Press, 2014.

Blaser, Mario. Storytelling Globalization from the Chaco and Beyond (New Ecologies for the Twenty-First Century). Durham: Duke University Press, 2010. 
Blecha, Jennifer and Helga Helga. "Reimagining the food system, the economy, and urban life: new urban chicken-keepers in US cities. Urban Geography 35 Issue 1 (2014): 86-108.

Blumm, Michael C and James Brunberg, "Not Much Less Necessary... Than the Atmosphere They Breathed: Salmon, Indian Treaties, and the Supreme Court - A Centennial Remembrance of United States V. Winans and Its Enduring Significance," Natural Resources Journal 46 (2006): 498.

Burden, Paul R. A Subject Guide to Quality Web Sites. Lantham, Toronto, Plymouth: The Scarecrow Press Inc., 2010.

Boxberger, Daniel L. To Fish in Common: The Ethnohistory of Lummi Indian Salmon Fishing. Seattle and London: University of Washington Press, 2000.

Bruyneel, Kevin. The Third Space of Sovereignty: The Postcolonial Politics of U.S.Indigenous Relations (Indigenous Americas). Minneapolis: University of Minnesota Press, 2007.

Byrd, Jodi A. The Transit of Empire: Indigenous Critiques of Colonialism. Minneapolis: University of Minnesota Press, 2011.

Byrd, Jodi A. "Variations Under Domestication: Indigeneity, Financialization, and the Logics of Dispossession" Talk, Social Justice Institute Noted Scholars Lecture Series, University of British Columbia, September 21, 2016.

Cadena, Marisol de la. Indigenous Cosmopolitics in the Andes: Conceptual Reflections Beyond 'Politics." Cultural Anthropology 25 no. 2 (2010): 334-370.

Cattelino, Jessica R. "The Double Bind of American Indian Need-Based Sovereignty" Cultural Anthropology 25, no. 2 (May 1, 2010): 235-62.

Chadwick, Martin, Harriet Trewin, Frances Gawthrop, and Carol Wagstaff. "Sesquiterpenoids Lactones: Benefits to Plants and People" International Journal of Molecular Science 14 no. 6 (June 2013).

Clifford, Henry. "AquAdvantage Salmon - a pioneering application of biotechnology in aquaculture.” 8(Suppl 4): O31. Published online 2014 Oct 1, 2014.

Cohen, Fay G. Treaties on Trial: The Continuing Controversy over Northwest Indian Fishing Rights. Seattle: University of Washington Press, 1986.

Cole, Douglas and Ira Chaikin, An Iron Hand upon the People: The Law against the Potlatch on the Northwest Coast (Vancouver and Toronto 1990 
Coulthard, Glen. Red Skin, White Masks: Rejecting the Colonial Politics of Recognition Minneapolis: University of Minnesota Press, 2014.

CRITFC (Columbia River Inter-Tribal Fish Commission) "Empty Promises, Empty Nets" Portland, OR” Wild Hare Media, VHS, 1994.

Cullather, Nick. The Hungry World: America's Cold War Battle against Poverty in Asia Cambridge: Harvard University Press, 2013.

Daigle, Michelle. "Tracing the terrain of Indigenous food sovereignties" Journal of Peasant Studies (July 2017).

Darly, Ségolène and Nathan McClintock. "Introduction to Urban Agriculture in the Neoliberal City: Critical European Perspectives" ACME: An International Journal for Critical Geographies 16 No. 2(2017): 224-231.

Dawson, Ashley. "Biocapitalism and Culture" Environments and Societies Colloquium UC Davis Humanities Institute. Davis, California, March 4, 2014.

Denn, Rebekah. "Local, seasonal, organic? Seattle food pioneer Mark Musick has been preaching it all for four decades," Seattle Times April 20, 2017.

Deleuze, Gilles, and Guattari, Félix. Anti-Oedipus: Capitalism and schizophrenia. Trans. Robert Hurley, Mark Seem, and Helen R. Lane. Minneapolis, MN: University of Minnesota Press, 1984.

Deleuze, Gilles, and Guattari, Félix. A Thousand Plateaus: Capitalism and Schizophrenia. Minneapolis: University of Minnesota Press, 1987.

Deur, Douglas and Nancy J. Turner (eds.). Keeping it Living: Traditions of Plant Use and Cultivation on the Northwest Coast of North America. Vancouver: UBC Press, 2006.

Dougherty, John J. "Talking the Language of the Larger World: Fishing Wars, Natural Resources, and Birth of the Native Sovereignty Movement" Western Legal History 27, No. 1 (Winter/Spring 2014).

Fawaz, Ramzi. "Settling Scores: Claiming Ground for Native and Indigenous Critique in the Americas" Review of The Transit of Empire: Indigenous Critiques of Colonialism by Jodi. A. Byrd. Anthropological Quarterly 85, No. 1 (2012): 257-272.

FWS, Fish and Wildlife Service. "Salmon Hatchery Questions \& Answers" https://www.fws.gov/arcata/fisheries/reports/tamwg/2008/March10-11/Attachment4.pdf Accessed April 16, 2018. 
Fournier, Matt "Lines of Flight" Transgender Studies Quarterly Volume 1, Number 12: 121-122, 2014.

Frank, Billy Jr. "Hatcheries Aren’t Habitat" Northwest Indian Fisheries Commission nwifc.com, 2004.

Frank, Billy Jr. "We need to win the battle for salmon recovery" Northwest Indian Fisheries Commission nwifc.com Feb. 6, 2012.

Gibbs, George. In Letter to Captain McClellan, qtd in Brief of Petitioners, Washington State, at 46, Washington v. Washington State Commercial Passenger Fishing Vessel Association, 443 U.S. 658 (No. 77-983), 1979.

Gilmore, Ruth Wilson. "Fatal Couplings of Power and Difference: Notes on Racism and Geography." The Professional Geographer 54 no. 1 (Feb. 2002)" 15-24.

Goeman, Mishuana. "From Place to Territories and Back Again: Centering Storied Land in the discussion of Indigenous Nation-building." International Journal of Critical Indigenous Studies 1, no. 1 (2008): 23-34.

Grande, Sandy. Red Pedagogy: Native American Social and Political Thought. Lanham: Roman \& Littlefield Publishers Inc., 2004.

Guthman, Julie. Agrarian Dreams: The Paradox of Organic Farming in California. Oakland: University of California Press, 2004.

Guthman, Julie. "Bringing good food to others: Investigating the subjects of alternative food practice." Cultural Geographies 15 no. 4 (2008), 431-447.

Guthman, Julie. Weighing in: Obesity, food justice, and the limits of capitalism. California Studies in Food and Culture Vol. 32. Berkeley: University of California Press, 2011.

Harper, Barbara and Stuart Harris. "Tribal Technical Issues in Risk Reduction Through Fish Advisories" in Proceedings of the American Fisheries Society: Forum on Contaminants in Fish (1999): 17-25.

Helmreich, Stefan. "Species of Biocapital." Science as Culture 17 no. 4 (2008): 463-478.

Holbraad, Martin, Pedersen, M. and Eduardo Vivieros de Castro. "The Politics of Ontology: Anthropological Positions. Fieldsights - Theorizing the Contemporary" Cultural Anthropology Online January 13, 2014.

Holt-Giménez, Eric. "Food crises, food regimes and food movements: rumblings of reform or tides of transformation?" Journal of Peasant Studies 38 no. 1(2008):109-44. 
Horst, Megan; McClintock, Nathan; Hoey, Lesli. "The Intersection of Planning, Urban Agriculture, and Food Justice: A Review of the Literature"Journal of the American Planning Association 83; No. 3 (SUM 2017): 277-p295.

Howe, Leanne "Chaos of Angels" Callaloo 17 no. 1, Native America Literatures (Winter 1994): 108-114.

Ingold, Timothy. "That's enough about ethnography!” HAU: Journal of Ethnographic Theory 4 no. 1 (2014): 383-395.

Kirksey, Eben and Brandon Costelloe-Kuehn, and Dorion Sagan. "Life in the Age of Biotechnology" in Eben Kirksey, ed., The Multispecies Salon. Durham: Duke University Press, 2014.

Kobayashi, Audrey. "Negotiating the Personal and Political in Critical Qualitative Research." in Qualitative Methodologies for Geographers: Issues and Debates, ed. Limb, M. and C. Dwyer. Oxford University Press, 2001, 55-70.

La Paperson. "A ghetto land pedagogy: an antidote for settler environmentalism" Environmental Education Research 20 no. 1 (2014) 115-130.

la paperson. A Third University is Possible Minneapolis: University of Minnesota Press, 2017.

Landecker, Hanna "Beyond the Sovereign Body: nutritional deficiencies: dietary advice and its discontents a conversation with Julie Guthman, Garrett Broad, Kendra Klein and Hanna Landecker" gastronomica: the journal of critical food studies 14 no.3 (2014): 4655.

Law, John. Sociology of Monsters: Essays on Power, Technology and Domination. London: Routledge, 1991.

Law, John. "Actor network theory and material semiotics" in Turner \& Bryan S. (eds.) The New Blackwell Companion to Social Theory, $3^{\text {rd }}$ Edition. Oxford: Blackwell. 2008.

Leibhardt, Barbara. Law, Environment, and Social Change in the Columbia River Basin: The Yakima Indian Nation as a Case Study, 1840-1933. Dissertation, University of California, Berkeley, 1990.

Jones, Krista L. "Umatilla River Vision,” October 1, 2008, 1-2, http://www.umatilla.nsn.us/DNRUmatillaRiverVision.pdf.

Latour, Bruno. We Have Never Been Modern. trans. Catherine Porter, Cambridge: Harvard University Press, 1993. 
Latour, Bruno. "Why Critique Has Run Out of Steam.” Critical Inquiry 30 (Winter 2004).

Latour, Bruno. An Inquiry into Modes of Existence: An Anthropology of the Moderns, trans. Catherine Porter, Cambridge: Harvard University Press, 2013.

Lewis, O. Yale III. "Treaty Fishing Rights: A Habitat Right as Part of the Trinity of Rights Implied By the Fishing Clause of the Stevens Treaties." American Indian Law Review 29 no. 1 (2002): 281-311.

Li, Tania Murray. "Articulating Indigenous Identity in Indonesia: Resource Politics and the Tribal Slot" Comparative Studies in Society and History 42 no.1 (January 2000): 149179.

Lichatowich, James A. Salmon Without Rivers: A History of The Pacific Salmon Crisis. Washington D.C.: Island Press, 1999.

Lien, Marianne and John Law. "Slippery: Field notes in empirical ontology." Social Studies of Science 43 no. 3 (2012): 363-378.

Lien, Marianne "Escapee, Homeless, and Those That 'Wander Off': Salmon as Rubble in Norwegian Rivers." Anthropocene: Arts of Living on a Damaged Planet Santa Cruz, California May 10, 2014. http://anthropocene.au.dk

Lien, Marianne. Becoming Salmon: Aquaculture and the Domestication of a Fish. Berkeley: University of California Press, 2015.

Locke, John. Two Treatises of Government and a Letter Concerning Toleration. Ed. Ian Shapiro. [1797] 2003.

Mann, Geoff and Joel Wainwright. Climate Leviathan: A Political Theory of Our Planetary Future. New York: Verso, 2018.

Mashudo, Steve. "Washington tribe joins legal challenge over modified salmon” U.S. News and World Report, July 19, 2016.

Mbembe, Achille. "Necropolitics” Public Culture 15 no. 1 (2003): 11-40.

Miller, S.A. "Native America writes back: The origin of the Indigenous paradigm in historiography." Wicazo Sa Review 23 no. 2 (2008): 9-28.

Morrill, Angie and Eve Tuck, and the Super Futures Haunt Qollective, "Before Dispossession, or Surviving It," Liminalities: A Journal of Performance Studies 12, no. 1 (2016). 
Morgensen, Scott. "Un-Settling Settler Desires." Unsettling America: Decolonization in Theory and Practice, September 8, 2011.

https://unsettlingamerica.wordpress.com/2011/09/08/un-settling-settler-desires/

Motenson-Robinson, Aileen. The White Possessive: Property, Power, and Indigenous Sovereignty Minneapolis: University of Minnesota Press, 2015a.

Motenson-Robinson, Aileen. "Aboriginal Sovereignty, Foucault, and the Limits of Power" presented at Indigenous Foucault Symposium Native Studies, University of Alberta, October 26, $2015 \mathrm{~b}$.

Musick, Mark. "The History of the Tilth Movement" Tilth Alliance Webpage. February 12, 2008. http://www.seattletilth.org/about/abriefhistoryoftilth

Ott, Brian Richard. "Indian Fishing Rights in the Pacific Northwest: The Need for Federal Intervention." Boston College Environmental Affairs Law Review 14 no. 2 (1987): 313-343.

Nash, Philleo "Indian Held Differing from Negro in Wishing to Preserve Own Culture" The Oregonian, July 27, 1963. Qtd. In Dougherty, John J. "Talking the Language of the Larger World: Fishing Wars, Natural Resources, and Birth of the Native Sovereignty Movement" Western Legal History 27, No. 1 (Winter/Spring 2014).

NCAI The National Congress of American Indians Resolution \#ANC-14-037 2014

Northwest Treaty Tribes, "The impacts of GMO salmon on tribal communities" video, nwifc.com, November 30, 2015.

Nyéléni. Proceedings of the Forum for Food Sovereignty held in Sélingué, Mali, February 23-27, 2007.

Parr, Adrian. The Wrath of Capital. New York: Columbia University Press, 2013.

Phillips, John. “Agencement/Assemblage.” Theory, Culture \& Society 23, 2-3 (2006): 108-09.

Pierce, Clayton. "Against neoliberal pedagogies of plants and people: mapping actor networks of biocapital in learning gardens" Environmental Education Research 21, No. 3 (2015): 460-477.

Piliaris, Lisa. "Growing Green Architecture" South Sound Green Pages (June/July 2007).

Poe, Melissa R.; McLain, Rebecca J.; Emery, Marla; Hurley, Patrick T. "Urban Forest Justice and the Rights to Wild Foods, Medicines, and Materials in the City" Human Ecology 41 No. 3 (June 2013): 409-p422. 
Potash, Laura and Martin, Joyce LeCompte-Mastenbrook, Warren KingGeorge, and Tracy Fuentes. "Management \& Monitoring Plan for the Enhancement of Big Huckleberry (Vaccinium membranaceum) in Government Meadows, Mt. BakerSnoqualmie National Forest." USDA Forest Service, Snoqualmie Ranger District, North Bend, WA, 2008.

Rains, Katie and Justin Umholtz. "A Case Study: Garden-Raised Bounty (GRuB): Everyone at the Table" in Sowing Seeds in the City Snyder, Elizabeth Hodges, Kristen McIvor, Sally Brown et al. (eds.), 2016.

Ramírez, Margaret. "The Elusive Inclusive: Black Food Geographies and Racialized Food Spaces” Antipode 47 Issue 3 (June 2015): 748-69.

Richards, Kent. “The Stevens Treaties of 1854-1855.” Oregon Historical Quarterly 106 No. 3, 2005.

Lindloff, Stephanie. Dam Removal: A Citizen's Guide to Restoring Rivers, River Alliance of Wisconsin and Trout Unlimited, 2000.

Roosth, Sophia. "What Synthetic Biology Has in Common With Queer Theory" Slate April 25, 2017.

Ruchty, Andrea. "Special Forest Products Position Statement and Sustainability Analysis for Big Huckleberry (Vaccinium membranaceum) Douglas ex Torr." Gifford Pinchot National Forest, 2008.

Schneider, Lindsey R. Dammed By the State: Indian Fishing and the Geographies of Settler Colonialism in the Columbia River Basin $\mathrm{PhD}$ diss., University of California, Riverside, 2016.

Segrest, Valerie. "How a Cup of Nettle Tea Taught Me How To Live Well and Remember the Past." Yes! Magazine December 18, 2013.

Segrest, Valerie. Qtd in “The Color of Food” by Natash Bowens, Gabriola Island: New Society Publishers, 2015.

Shiva, Vandana. Biopiracy: The Plunder of Nature and Knowledge. Boston, South End Press, 1999.

Simpson, “Audra Settlement's Secret” Cultural Anthropology Vol 26 Issue 2 pp 205-217, 2011.

Simpson, Audra. Mohawk interruptus: Political life across the borders of settler states. Durham: Duke University Press, 2014. 
Simpson, Audra. "Consent's Revenge." Cultural Anthropology 31, no. 3 (2016): 326333.

Slocum, Rachel and Arun Saldanha. Geographies of Race and Food: Fields, Bodies, and Markets New York: Ashgate Publishing, 2013.

Spice, Anne. "Processing Settler Toxicities: Part I" Footnotes. multimodal anticolonial iconoclastic, June 2018.

Sunberg, Juanita. "Decolonizing posthumanist geographies" Cultural Geographies 21 (2014): 33-47.

Sunder Rajan, Kaushik. Biocapital: The Constitution of Postgenomic Life. Durham, NC: Duke University Press, 2006.

TallBear, Kimberly. 'There is no DNA test to prove you're Native American' New Scientist, Feb. 52014.

Taylor, Joseph E. Making Salmon: An Environmental History of the Northwest Fisheries Crisis, Revised ed. Seattle: University of Washington Press, 2001.

Tali, Haller and Katie Gubbe. "Plant Seeds of Love with GRuB" ThurstonTalk Editor June 9, 2014.

TallBear, Kim "Why Interspecies Thinking Needs Indigenous Standpoints" Theorizing the Contemporary, Cultural Anthropology website, April 24, 2011.

Rifkin, Mark. The Transit of Empire: Indigenous Critiques of Colonialism (review) Studies in American Indian Literatures University of Nebraska Press 24, no. 4 (Winter 2012): 138-142.

Sharma, Nandita, and Cynthia Wright. "Decolonizing Resistance, Challenging Colonial States." Social Justice 35, no. 3 (2008): 120-38.

Sinclaire Allen, Jafari and Ryan Cecil Jobson. "The Decolonizing Generation: (Race and) Theory in Anthropology since the Eighties" Current Anthropology 57 no. 2 (2016): 129148.

Snyder, Elizabeth Hodges, Kristen McIvor, Sally Brown et al. (eds.), Sowing Seeds in the City: Human Dimensions Netherlands: Springer, 2016.

Stotish, Ron. AquaBounty.com accessed 6/5/2017

Suttles, Wayne and D. Cole, I. Caikin, Coast Salish Essays Seattle: University of Washington Press, 1990. 
The Suquamish Tribe, Fish Consumption Survey of the Suquamish Tribe of the Port Madison Indian Reservation, Puget Sound Region 4, 2000.

Tillamook. “Our Story.” https://www.tillamook.com [Accessed 4, April 2018].

Todd, Zoe "An Indigenous Feminist Take On The Ontological Turn: 'Ontology is Just Another Word for Colonialism” Journal of Historical Sociology 29 no. 1 (March 2016).

Todd, Zoe "Commentary: The Environmental Anthropology of Settler Colonialism, Part I: Engagement on the Frontier." Anthropology and Environment Engagement Blog, April 11, 2017.

Tsing, Anna Lowenhaupt. Friction: An Ethnography of Global Connection. Princeton, NJ: Princeton University Press, 2005.

Tsing, Anna Lowenhaupt. The Mushroom at the End of the World: On the Possibility of Life at the End of Capitalist Ruins. Princeton: Princeton University Press, 2017

Tuck, Eve and Ruben Gaztambide-Fernández. "Curriculum, replacement, and settler futurity." Journal of Curriculum Theorizing 29 no. 1, 2013

Tuck, Eve and Marcia McKenzie. "Place in Research: Theory, Methodology, and Methods"

In Land Education: Rethinking Pedagogies of Place from Indigenous, Postcolonial, and Decolonizing Perspectives McCoy, Kate, Eve Tuck, an Marcia McKenzie eds. New York: Routledge, 2016.

Tuck, Eve and C. Ree. "A Glossary of Haunting." In Handbook of Autoethnography, Stacey Holman Jones, Tony E. Adams, and Carolyn Ellis eds. Left Coast Press, Inc., 2013.

Tuck, Eve and K. Wayne Yang. Toward What Justice?: Describing Diverse Dreams of Justice in Education New York: Routledge, 2018.

Turner, Nancy J., Douglas Deur, and Dana Leposfky. "Plant Management Systems of British Colombia's First Peoples" The British Columbian Quarterly: Ethnobotany in British Columbia no. 179 (Autumn 2013) 107-133.

United States v. Washington, 384 F. Supp. 312 (W.D. Wash. 1974), aff'd, 520 F.2d 676 (9th Cir. 1975).

University of Washington Center for Creative Conservation "Camas Prairie Cultural Ecosystem Incubator" http://conservation.uw.edu/current-work/camas-prairie-culturalecosystems-incubator/ Accessed November 3, 2017. 
Vancouver, George. A Voyage of Discovery to the North Pacific Ocean and Round the World, 1791-1795, vol.II. W, Kaye Lamb ed. London, 1984, 568.

Viveiros de Castro, Eduardo. Cited in Holbraad, Martin, Pedersen, M. and Eduardo Vivieros de Castro. "The Politics of Ontology: Anthropological Positions. Fieldsights Theorizing the Contemporary” Cultural Anthropology Online, January 13, 2014.

Viveiros de Castro, Eduardo. Cannabal Metaphysics: For a Post-Structural Anthropology Trans. Peter Skafish, Minneapolois: Univocal, 2014.

Watts, Michael. "Space for Everything (A Commentary)." Cultural Anthropology 7 no. 1 (1992):115-29.

Welch, Craig. "Billy Frank Jr.: Champion of tribal rights dies at age 83." Seattle Times May 5, 2014.

WəłəbPaltx ${ }^{\mathrm{w}}$ https://www.washington.edu/diversity/tribal-relations/intellectual-house/ 2016

West, Paige. From Modern Production to Imagined Primitive: The Social World of Coffee from Papua New Guinea. Durham: Duke University Press, 2012.

Wilkinson, Charles F. Messages from Frank's Landing: A Story of Salmon, Treaties, and the Indian Way. Seattle: University of Washington Press, 2000.

White, Richard. The Organic Machine: The Remaking of the Columbia River. New York: Hill and Wang, 1995.

Willson, M. F. and K. C. Halupka. "Anadromous fish as keystone species in vertebrate communities." Conservation Biology 3 (1995): 489-497.

Wolfe, Patrick. Settler Colonialism and the Transformation of Anthropology: The Politics and Poetics of an Ethnographic Event. London: Cassell, 1999.

Wunder, John. "Retained by the People": A History of American Indians and the Bill of Rights. Oxford: Oxford University Press, 1994. 
VITA

\section{JANNA LAFFERTY}

Born, Hartford, Connecticut, United States

2004

B.A., Anthropology, Religion

University of California, San Diego

La Jolla, California

2007

M.A., Religion

Duke University

Durham, North Carolina

2018

Ph.D., Global and Sociocultural Studies

Florida International University

Miami, Florida

$2011-2012$

Teaching Assistant

Florida International University

Miami, Florida

$2012-2014$

Instructor of Record

Florida International University

Miami, Florida

$2014-2018$

Doctoral Candidate

Florida International University

Miami, Florida

\section{PUBLICATIONS and PRESENTATIONS}

Lafferty, Janna.

Troubling Place in Alternative Food Practices: Food Movements, Neoliberalism, and Place" in Place-Based Perspectives on Food in Society. Keven Fitzpatrick and Don Willis (eds). New York: Macmillan/Palgrave Publishers, 2015.

Ryser, Rudolph, Yvonne Sherwood, and Janna Lafferty.

"Fourth World Nations Under the Nuclear Cloud: Exposing Indigenous Nations to Radioactivity" Intercontinental Cry, April, 2016. 
Lafferty, Janna.

"Salmon People, Biotechnology, and the Politics of Refusal in Coast Salish Territories and the Settler Colonial Present," presented at the Biennial Meeting for the Society of Cultural Anthropology, Cosponsored by the Society for Visual Anthropology, March, 2018.

Lafferty, Janna.

"Salmon People in the Age of Biocapital and Biotech Food Production: Mare Nullius, Settler Colonialism, and GMO Salmon Politics in Coast Salish Territories" presented at the Society of Economic Anthropology Annual Meeting: Water and Economy, March 2018.

Lafferty, Janna.

"Articulating Coast Salish Food Sovereignty: Tribal Sovereignty and Alternative Food Geographies in the US Pacific Northwest," presented at the American Association of Geographers Annual Meeting, March 2016.

Lafferty, Janna. "Growing Movement to Revitalize Traditional Food Economies: Toward a Political Ecology of Diabetes," presented at the Dimensions of Political Ecology Conference on Nature/Society, March 2012. 